\author{
Universidade de São Paulo \\ Instituto de Física \\ Instituto de Química \\ Instituto de Biociências \\ Faculdade de Educação
}

\title{
A pluralidade da relação entre a física e a matemática em um curso inicial de licenciatura em Física
}

Andreza Fernanda Concheti 


\author{
Universidade de São Paulo \\ Instituto de Física \\ Instituto de Química \\ Instituto de Biociências \\ Faculdade de Educação
}

\title{
A pluralidade da relação entre a física e a matemática em um curso inicial de licenciatura em Física
}

\author{
Andreza Fernanda Concheti
}

Orientadora: Prof ${ }^{\mathrm{a}}$. Dra. Cristina Leite

Dissertação de mestrado apresentada ao Instituto de Física, ao Instituto de Química, ao Instituto de Biociências e a Faculdade de Educação da Universidade de São Paulo, para a obtenção do título de Mestre em Ensino de Ciências Modalidade Física.

Comissão Examinadora:

Prof $^{a}$ Dra. Cristina Leite (Presidente)

Prof $^{a}$ Dra. Maria Regina Dubeux Kawamura

Prof $^{\circ}$ Dr. Ricardo Avelar Karam

São Paulo

2015 
Autorizo a reprodução e divulgação total ou parcial deste trabalho, por qualquer meio convencional ou eletrônico, para fins de estudo e pesquisa, desde que citada a fonte.

\section{FICHA CATALOGRÁFICA \\ Preparada pelo Serviço de Biblioteca e Informação do Instituto de Física da Universidade de São Paulo}

\section{Concheti, Andreza Fernanda}

A pluralidade da relação entre a física e a matemática em um curso inicial de licenciatura em física. São Paulo, 2014.

Dissertação (Mestrado) - Universidade de São Paulo. Faculdade de Educação, Instituto de Física, Instituto de Química e Instituto de Biociências.

Orientador: Profa. Dra. Cristina Leite

Área de Concentração: Ensino de Física

Unitermos: 1. Física - Estudo e ensino; 2. Educação; 3. Ensino superior; 4. Matemática - Estudo e ensino; 5. Estudo de caso.

USP/IF/SBI-102/2014

São Paulo 
"Osé plural como o Zhniverso"

Ofernando Dessoa 
Alos meus pais, pela confianca e ternura. 


\section{Agradecimentos}

Agradeço primeiramente à minha família: a minha mãe Fatima que constantemente transmite paz, amor, fé e proteção com suas orações, ao meu pai Geraldo, que é um exemplo de homem sábio, humilde e simples, ao meu irmão Maicon, que esteve presente em várias cenas importantes da minha vida, como na matrícula na universidade, ao meu irmão Roberval pelo grande coração e orgulho das minhas conquistas, à minha cunhada Danielle pelo apoio, torcida e carinho de irmã, ao meu sobrinho Gabriel pela alegria sincera em cada reencontro e aos meus avós Luisa e Geraldo que ainda vivem diariamente em minhas lembranças mais alegres e acolhedoras.

Agradeço à orientadora Cristina Leite por acolher o tema da pesquisa e pela paciência na orientação nesses últimos e longos anos de pesquisa.

Aos grandes professores e pesquisadores que marcaram positivamente minha passagem pelo Instituto de Física: Manoel Robilotta, que instigou essa pesquisa e participou de várias reuniões e discussões sobre a temática da dissertação, contribuindo e inspirando o trabalho acadêmico e o olhar para o ensino e aprendizagem da física. À Bia, que também contribuiu significativamente nas reuniões e reflexões sobre a relação da matemática com a física. Ao Ivã pelas conversas e trocas no corredor de ensino e no estágio PAE.

Agradeço à Maria Regina pelo apoio generoso e atencioso em várias etapas desse processo, principalmente a finalização. Agradeço pelas suas aulas na graduação, pelo apoio na pesquisa e na vida acadêmica e pelas palavras afáveis, tranquilizadoras e encorajadoras.

Agradeço às queridas amigas Paulinha e Analu pela ajuda gratuita e bondosa na finalização da dissertação e no amparo nos momentos difíceis, na vida acadêmica e pessoal.

Agradeço à Graciella pelas orientações e conselhos nesses últimos dez anos de amizade e formação acadêmica. Agradeço também às colegas de pesquisa e do corredor de ensino: Renatinha, Suzana, Leika, Flávia, Marta, Daniel, Vanessa e Valéria pelas trocas enriquecedoras.

Agradeço aos velhos e novos amigos: Marília, Naiara, Fernando, Leo, Sérgio, Luis Eduardo, Bruno, Bruna, Robertinha, Célia, Fernanda, Zé, Lilian, Pedro e Teresa; aos "antigos" pelas revividas histórias felizes do passado em momentos presentes e aos "novos" pela edificação atual de memórias agradáveis e alegres.

Agradeço aos amigos e companheiros do Colégio Miguel de Cervantes pelo apoio, confiança no meu trabalho e carinho: Solange, Cazé, Wolney, e Paulinha. 
Agradeço à equipe de professores pelo constante respeito e união no dia a dia e a colaboração do Fabio, das orientadoras Valéria e Katia, do Antonio e da direção administrativa e pedagógica.

Agradeço à CPGI e ao Tomas pela prestatividade e atenção desprendidos em seus atendimentos. 


\section{Sumário}

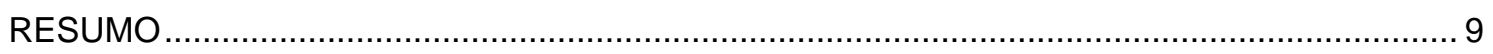

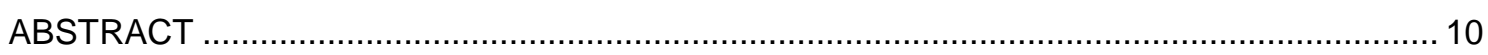

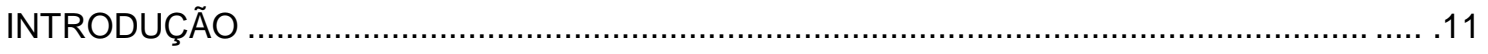

CAPÍTULO 1: A RELAÇÃO DA FÍSICA COM A MATEMÁTICA NA PESQUISA EM ENSINO DE

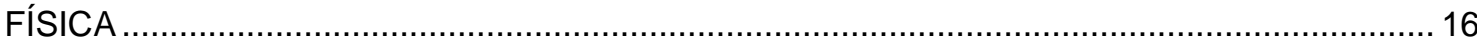

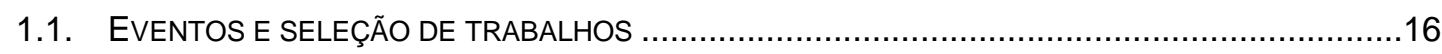

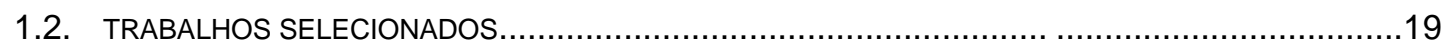

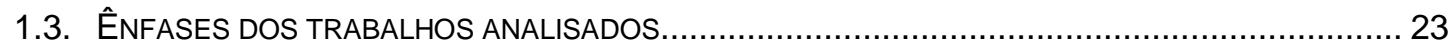

1.4. SíNTESE DOS CAMPOS TEMÁTICOS MAIS EXPLORADOS NOS EVENTOS................................2 24

CAPÍTULO 2: RELAÇÃO DA FÍSICA COM A MATEMÁTICA: CARÁTER TÉCNICO E CARÁTER

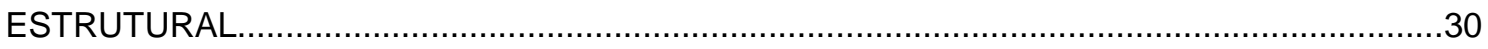

CAPÍTULO 3: METODOLOGIA NO DESENVOLVIMENTO DA PESQUISA ............................. 35

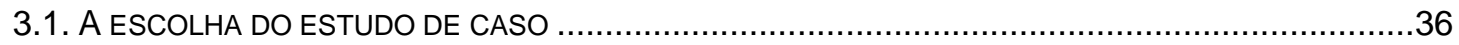

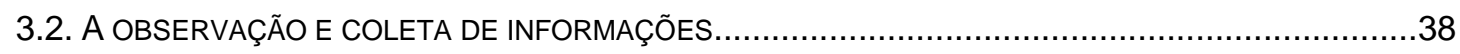

CAPÍTULO 4: REPRESENTAÇÃO MATEMÁTICA EM UM CURSO DE LICENCIATURA EM FÍSICA

. .40

4.1. TURMA A

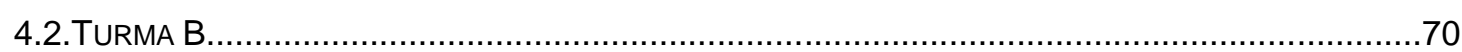

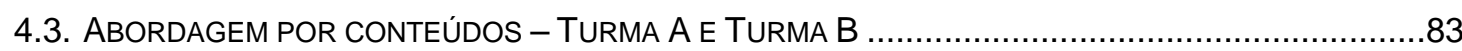

CAPÍTULO 5: CARÁTER TÉCNICO E RELACIONAL DA RELAÇÃO DA FÍSICA COM A MATEMÁTICA EM UM CURSO DE LICENCIATURA EM FÍSICA ….......................................8

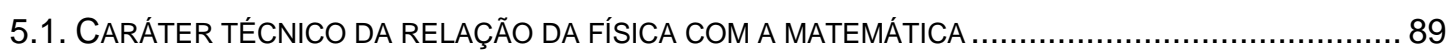

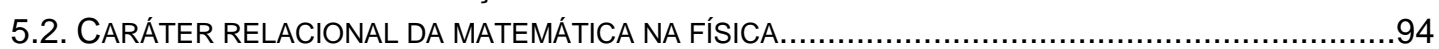

5.3. A LINGUAGEM MATEMÁTICA E A ESTRUTURAÇÃO DA FÍSICA ...............................................100

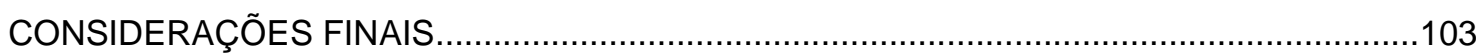

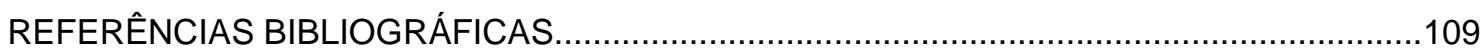

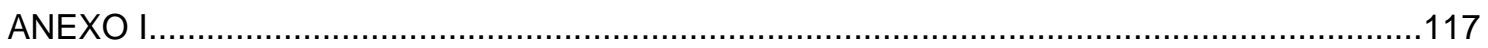

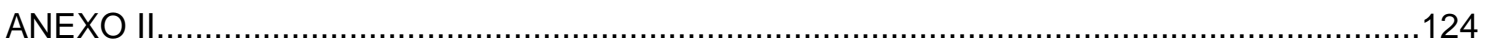




\section{Resumo}

CONCHETI, F.A. A pluralidade da relação entre a física e a matemática em um curso inicial da licenciatura em Física. 2014. Dissertação (Mestrado em Ensino de Física) - Instituto de Física - Instituto de Química - Instituto de Biociências - Faculdade de Educação - Universidade de São Paulo, São Paulo, 2014.

A física se relaciona intimamente com a matemática, e essa relação pode ser refletida com olhares distintos e complementares. A respeito dessa temática, existem trabalhos que discutem o papel técnico e operacional que a matemática exerce em diferentes níveis de ensino de física, assim como existem trabalhos que refletem sobre o caráter organizacional e estrutural que ela possui no ensino, construção e aprendizagem da ciência. Esse trabalho tem como principal objetivo observar esses dois tipos de relações em um curso introdutório de mecânica na licenciatura em física da Universidade de São Paulo e refletir sobre como as relações da física com a matemática podem ser apresentadas no contato inicial na graduação que o futuro professor de física tem com os conceitos da mecânica. Para isso, foi realizado um estudo de caso na disciplina Fundamentos de Mecânica em duas turmas com professores distintos. Nesse estudo, foram gravados áudios das explicações dos professores e anotadas as formulações matemáticas utilizadas nas aulas, como equações, resolução de exercícios e/ou esboços de gráficos. Em um primeiro momento, foram analisadas as representações matemáticas utilizadas pelos professores em trechos das aulas denominados episódios de ensino. Nesses episódios, se observaram aspectos como a transitividade de representações matemáticas, o aspecto operacional da matemática e as relações explícitas com outros cursos da licenciatura, como o cálculo e a geometria analítica. Em um segundo momento, foram analisados os aspectos organizacionais da matemática na física presentes no estudo de caso que permitem pensar a matemática como estruturante do pensamento físico (PIETROCOLA, 2002): interpretação, significação, abstração e linguagem matemática. Com essas análises, foi possível concluir que a relação da física com a matemática pode ser explorada no início da formação do professor em aspectos que extrapolam o uso técnico e mecânico das operações: a reflexão sobre a utilização das representações, a extração de informações físicas a partir de formulações e o exercício de pensar e ouvir questionamentos sobre o uso da matemática na física. A partir dessas apresentações, emergem outros questionamentos para a área de ensino de física: quando o futuro professor começa a pensar sobre a relação da física com a matemática? Quais as implicações de um curso introdutório em mecânica ser oferecido concomitantemente com um curso matemático de cálculo, por exemplo? Essa dissertação busca oferecer explanações que permitam levantar questões para futuras pesquisas na área e contribuir para a discussão sobre o tema.

Palavras chave: relação da matemática com a física, licenciatura em física, mecânica. 


\begin{abstract}
CONCHETI, F.A. The plurality of the relationship between physics and mathematics at an early degree course in Physics. 2014. Dissertation (Master in Physics Education) - Physics Institute - Chemistry Institute Biology Institute - Education Faculty - University of São Paulo, 2014.
\end{abstract}

Physics is closely related to mathematics, and this relationship can be seen with different and complementary points of view. Regarding this issue, there are studies that discuss the technical and operational role that mathematics plays in different levels of the education of physics, and there are works that focus on the organizational and structural nature that it has in education, construction and learning of science. This work is aimed at evaluate these two types of relationships in an introductory course in the degree in Physics from the University of Sao Paulo and think about on how the relations of Physics and Mathematics can be presented in the initial contact at the beginning of the university studies that the future teachers of Physics with the concepts of mechanics. For this, a case study in Mechanical Fundamentals course was conducted in two classes with different teachers. In this study, the audio recordings of the teachers explanations were made and noted the mathematical formulations, used in class were noted, as equations, problem solving and/or graphic sketches. At first, we analyzed the mathematical representations used by teachers in parts of classes called episodes of education. In those episodes, aspects such as transitivity mathematical representations, the operational aspect of mathematics and relationships with other courses of degree, such as calculus and analytic geometry, were as noted a second step; the organizational aspects of mathematics in Physics were analyzed to consider Mathematics as a structure for the physical thought (PIETROCOLA, 2002): interpretation, meaning, abstraction and mathematical language. With these analyzes, it was concluded that the physical relationship with mathematics can be explored at the beginning of a teacher training in aspects that go beyond the technical and mechanical use of the operations: a reflection on the use of representations, extraction of physical information from formulations and the exercise of thinking and hearing questions about the use of Mathematics in Physics. From these presentations, other questions emerge for the area of physical education: when the future teacher begins think about the physical relationship with Mathematics? What are the implications if an introductory course in Mechanics is offered concurrently with a Mathematical Calculus course, for example? This dissertation seeks to offer explanations that enable the raise of questions for future researches in the area and contribute to discussion on the topic.

Keywords: relation of mathematics to physics, physics degree, mechanical. 


\section{Introdução}

Logo no início da minha graduação na Licenciatura em Física, no segundo ano do curso, comecei a sentir a multiplicidade de ações que a profissão de professora permite experimentar, como por exemplo, o aprender e o ensinar.

Ao pensar o ensino e aprendizagem da Física, nas minhas reflexões, uma das questões presentes foi como discorrer a relação da física com a matemática, desde a construção da própria ciência até uma aula no ensino básico.

Concomitantemente com meus questionamentos pessoais a respeito do tema, a constante autoanálise sobre meu trabalho como professora corroborou para que, ao cursar a disciplina de pós-graduação "Complementos de Relatividade" com o professor Manoel Robilotta, eu organizasse algumas percepções no ensaio final do curso que tinha como tema proposto a relação da física com a matemática. Esse ensaio final (que está anexado à dissertação) juntamente com o apoio e incentivo do professor, foi o estopim para a pesquisa aqui apresentada.

Muitas pesquisas na área de ensino trabalham com essa temática focadas no ensino médio ou no ensino fundamental trazendo as interferências da matemática no ensino de física, como por exemplo, como as dificuldades nas operações matemáticas interferem nas aulas de física. Outras pesquisas discutem historicamente e epistemologicamente a construção da ciência com o auxílio da matemática. $O$ trabalho apresentado nessa dissertação não se enquadra nos enfoques citados acima.

Considerando que o primeiro contato com um formalismo matemático mais complexo na formação de um futuro professor de física - que terá a missão de transmitir seus conhecimentos e incitar a reflexão dos estudantes no nível médio se dá já no primeiro ano de faculdade, optou-se em focar a pesquisa nesse primeiro contato que o aluno tem na graduação em uma disciplina inicial de licenciatura, ou seja, no nível superior. 
Acredito que essas primeiras percepções são fundamentais na formação do pensamento crítico intuitivo do aluno futuro educador, e por isso, analisar como a relação da física com a matemática se estabelece nesse primeiro contato pode explanar algumas habilidades e reflexões que os alunos precisariam desenvolver em sua formação. É o intuito dessa pesquisa trazer algumas das possíveis relações da física com a matemática no contexto explicitado acima tendo como norte os trabalhos de PIETROCOLA $(2002,2005)$ e KARAM (2012).

Nas pesquisas com professores da rede básica de ensino, existe um reconhecimento que a física está intimamente relacionada à matemática. Segundo PIETROCOLA (2005), professores não têm dúvidas de que sem habilidades em lidar com operações matemáticas não é possível realizar boa ciência, por isso a maioria dos cursos básicos de ciências são dedicados à formação de uma base matemática. Muitos professores creditam à matemática as dificuldades que seus alunos têm em aprender física. LOCATELLI (2004) explicita essa ideia:

Mas como, no ensino das ciências, uma linguagem matemática precária e a dificuldade em quantificar os conceitos físicos e relacionar variáveis são, muitas vezes, fatores considerados responsáveis pelo fracasso escolar, frequentemente os professores alegam que seus alunos não entendem a física devido à fragilidade de seus conhecimentos em matemática. LOCATELLI (2004:2)

A responsabilização da matemática nas dificuldades de aprendizagem em física é limitante, pois não aborda outros aspectos essenciais no ensino dessa ciência, como por exemplo, o desenvolvimento histórico dos conceitos e fenômenos da Física.

Esse olhar mais direcionado que os professores têm sobre a matemática na física é oriundo principalmente pelo fato de que no ensino trabalha-se muito com resolução de problemas quantitativos que necessitam de um desenvolvimento matemático. MARTINI (2006), ao discutir o papel da matemática na resolução de problemas na escola básica, menciona o caráter instrumental que muitas vezes é enfatizado nas escolas: 
[...] em relação ao ensino de física "tradicional", a matemática se prestaria tão somente a ser pré-requisito não para a aquisição do conhecimento físico, mas para a resolução de exercícios ou de problemas, o que privilegiaria seu caráter instrumental. MARTINI (2006: 12)

O caráter instrumental mencionado pela pesquisadora refere-se à repetição metódica de exercícios "padrões" - um mesmo exercício variando os dados numéricos, por exemplo - como atividade prioritária no ensino, sem que haja reflexões acerca dos resultados encontrados.

A ênfase no caráter instrumental no ensino de Física traz o que muitos pesquisadores denominam "matematização" da Física. A respeito disso, LOZADA (2008) comenta:

A resolução de problemas nas aulas de Física no Ensino Médio, como se tem observado muitas vezes consiste na aplicação de fórmulas sem aparente relação com o conceito físico, constituindo-se em mecanização de procedimentos, propagando o que se tem denominado "matematização" do Ensino de Física. Este processo de "matematização" caracteriza-se pela excessiva ênfase na apropriação de conceitos matemáticos para resolver problemas de Física, relegando a segundo plano a conexão com os fenômenos físicos em estudo. LOZADA (2008: 2)

Existem inúmeras críticas ao modo como a física é ensinada, principalmente no Ensino Médio, com um número excessivo de exercícios repetitivos e enfoque na resolução destes exercícios. No entanto, sabemos que a Física estudada na escola não representa a física na sua essência, e tão pouco essa relação superficial entre a física e a matemática na escola básica representa a grandiosidade e complexidade existente entre elas.

Nesse trabalho a palavra "matematização" não será utilizada pensando no uso exclusivo de equações e procedimentos matemáticos em resolução de problemas - no sentido citado anteriormente pelos autores - e sim, será pensada 
como uma das etapas (que extrapola a repetição numérica) que permitem construir o conhecimento físico.

Acreditamos não ser possível ensinar ou aprender física sem a matemática, ao mesmo tempo acreditamos também que saber matemática não garante que um aluno aprenderá Física. O grande desafio consta em qual abordagem e visão é trazida dentro das aulas e como essa relação é desenvolvida.

Essa questão depende intimamente da formação do professor, já que as concepções adquiridas na sua formação são levadas para o ensino básico. KARAM (2009) argumenta que no ensino superior a matemática é apresentada estratificada, ou seja, no ensino superior a matemática é separada da física em disciplinas, como ocorre no ensino básico:

No ensino superior encontramos situação semelhante, pois não se costuma pensar em uma abordagem integradora ao se estruturar um currículo. Baseando-se na ideia de que seja necessário dominar o ferramental matemático primeiramente, os cursos da área de exatas iniciam com disciplinas matemáticas, como Cálculo e Geometria Analítica, para posteriormente mencionar aplicações das mesmas nas disciplinas da Física. KARAM (2009: 6).

O fato de a física ser integrada à matemática na sua concepção e aprendizagem e estar dissociada nos diversos níveis de ensino, inclusive no superior, interfere na formação dos professores de física.

A utilização da matemática no ensino e aprendizagem de física é crescente quando se analisa o ensino de ciências e física desde o ensino básico (fundamental), passando pelo ensino médio até o ensino superior. As relações aparentes entre a matemática e a física nesses diversos níveis são semelhantes, diferenciando somente pelo grau de complexidade que essas relações estabelecem em cada nível escolar.

Para delimitar e conhecer as pesquisas na área de Ensino de Física que têm como temática a relação da física com a matemática, no primeiro capítulo da dissertação é apresentada uma revisão bibliográfica de todos os trabalhos 
publicados com essa temática na última década em dois grandes eventos da área, o SNEF (Simpósio Nacional de Ensino de Física) e o EPEF (Encontro de Pesquisa em Ensino de Física). Nesse mesmo capítulo também é realizada uma sistematização dos principais enfoques que esses trabalhos apresentam, mapeando as principais abordagens nas pesquisas realizadas.

Em seguida, no segundo capítulo são levantados brevemente tópicos mais frequentes nas discussões acerca da relação da física com a matemática e os principais referenciais teóricos utilizados na pesquisa são explicitados.

No terceiro capítulo é descrita a metodologia de pesquisa apresentando detalhadamente o estudo de caso e as justificativas para as escolhas efetuadas na pesquisa.

No capítulo 4, o estudo de caso é dividido em trechos que foram denominados "episódios de ensino" e para cada episódio são analisados os aspectos técnicos da matemática na física: as representações numéricas, simbólicas e a abordagem didática dos conteúdos ensinados.

Na sequência, no capítulo 5, são extraídos excertos dos episódios de ensino e estes são discutidos observando o caráter técnico e o caráter relacional da relação da física com a matemática. A partir dessa discussão, são obtidas algumas conclusões da articulação dos diferentes papéis que a matemática exerce na física.

Finalizando, as considerações finais apresentam uma conclusão e delimitam as perspectivas que a pesquisa traz para o Ensino de Física e as possibilidades de investigações futuras, incitando o questionamento de outras questões relacionadas à pesquisa que não foram discutidas e exploradas nesse trabalho. 


\section{Capítulo 1}

\section{A relação da física com a matemática na pesquisa em Ensino de Física}

Ao aprender, ensinar ou pensar física é praticamente impossível não transitar por outra área de conhecimento: a matemática. Seja por sua constante presença nas equações, deduções ou mecanismos lógico-dedutivos, a matemática possui uma importante atuação nessa ciência, e por isso, ao discutir o Ensino de Física, é esperado encontrar reflexões a respeito da relação da física com a matemática.

Apesar disso, não é possível encontrar na literatura muitas pesquisas que tem como intuito investigar as relações entre a física e a matemática no ensino (KARAM, 2012, p.37).

Para mapear as reflexões existentes a respeito dessa relação na área de Ensino de Física, nesse capítulo é apresentada uma sistematização de todas as publicações encontradas que discutem a relação da física com a matemática -seja no ensino, na aprendizagem ou na história das ciências - na última década em dois grandes eventos da área (o SNEF -Simpósio Nacional de Ensino de Física - e o EPEF -Encontro de Pesquisa em Ensino de Física).

\subsection{Eventos e seleção de trabalhos}

O SNEF (Simpósio Nacional de Ensino de Física) é um evento bianual promovido pela Sociedade Brasileira de Física (SBF) que reúne pesquisadores da área de Ensino de Física, alunos de graduação e pós-graduação, professores do ensino básico e público em geral interessado no debate das questões relacionadas à aprendizagem e ensino de Física.

Além de apresentar os resultados e reflexões da pesquisa na área de Ensino de Física no formato pôster ou Comunicação Oral, no SNEF os participantes podem inscrever trabalhos que vão desde a descrição de relatos de suas atividades de pesquisa e docência até propostas de ensino na área, permitindo uma participação mais ativa da comunidade externa no evento, como por exemplo, de professores das redes públicas e particulares de ensino e alunos do ensino básico. 
O Encontro de Pesquisa em Ensino de Física (EPEF) também é um evento bianual promovido pela Sociedade Brasileira de Física (SBF), intercalando os anos com o SNEF. Esse evento tem uma dimensão e alcance menor que o SNEF, já que tem explicitamente como público alvo pesquisadores e alunos de pós-graduação da área de Ensino de Física. Por conta disso, o número de participantes e trabalhos apresentados é relativamente menor em comparação com o SNEF.

Na submissão de trabalhos dos eventos existem opções de campos temáticos para diferenciação e organização das publicações, como por exemplo, o campo da formação do professor de Física, alfabetização científica e tecnológica e ensino de Física, tecnologias no ensino de Física, Filosofia, História e Sociologia da Ciência e Ensino de Física, Divulgação Científica e Comunicação no Ensino de Física, Interdisciplinaridade e Ensino de Física, etc.

Para a iniciação da pesquisa das publicações que discutem ou apresentam as relações da física com a matemática nos eventos, o primeiro procedimento foi sistematizar as possibilidades de investigação e discussão do tema nos campos temáticos. Na formação do professor de Física, por exemplo, é possível discutir o papel da matemática na sua prática e formação, na Filosofia, História e Sociologia da Ciência e Ensino de Física, é possível descrever a formulação de leis físicas através do desenvolvimento matemático, assim como em todos os campos temáticos é possível explorar a relação da física com a matemática com óticas e perspectivas diferentes. Por conta disso todos os trabalhos dos eventos (que foram apresentados no formato pôster ou comunicação oral), independentemente do campo temático que eles estavam inseridos, foram considerados.

Após a definição do campo amostral da busca, foram definidos os critérios de busca. Para realizar uma separação inicial dos possíveis trabalhos que discutiam a relação da física com a matemática, definiu-se a busca de todos os títulos e palavras-chave com a ocorrência das palavras: "matemática", "matemático", "modelagem matemática", "instrumental matemático", "interdisciplinaridade matemática e física". Partindo do princípio que outros títulos de trabalhos que não possuíam essas palavras poderiam discutir essa relação, optou-se pela leitura dos títulos e palavras-chave de cada trabalho apresentado nos eventos em detrimento de uma busca automática realizada por pesquisa com palavras. De fato, essa opção 
de análise minuciosa e manual mostrou-se no decorrer da busca eficiente e trouxe outros títulos de trabalhos que discutiam a temática com palavras como "cálculo numérico", "relações proporcionais" etc.

Após a definição dos parâmetros de busca, para cada evento foram realizados os procedimentos: primeiramente foi contabilizada a quantidade de trabalhos apresentados no evento, seja em formato pôster ou comunicação oral. Depois, o título e as palavras-chave de cada trabalho foram lidos e, aqueles que possuíam as palavras definidas a priori para a busca ou outras palavras que poderiam sugerir um trabalho sobre a temática da relação da física com a matemática, foram selecionados e separados. No término da pré-seleção de cada evento, os trabalhos selecionados foram abertos, e os resumos foram lidos para averiguação. No caso de dúvida, o trabalho todo foi lido para definir a inclusão ou exclusão na relação final de publicações que contém essa temática. Os trabalhos que, apesar de conter palavras-chave definidas na metodologia de busca não apresentavam uma discussão a respeito das relações envolvidas entre a física e a matemática, como por exemplo, trabalhos que só mostravam a dedução de uma equação física (semelhante a livros didáticos) foram excluídos.

No levantamento e sistematização das publicações dos eventos, algumas dificuldades foram recorrentes. Por exemplo, nos eventos que possuíam atas publicadas (SNEF 2003, SNEF 2005, SNEF 2007, EPEF 2004, EPEF 2006 e EPEF 2008) o número total de trabalhos apresentados só era citado no SNEF 2003. Nos outros, só era possível ter acesso a uma listagem de todos os trabalhos por ordem alfabética. Para descobrir a quantidade de trabalhos, foi utilizado um mecanismo de busca no navegador de internet com as palavras "palavras-chave:" na listagem, já que essa composição aparecia uma vez em cada trabalho e o por isso o número de ocorrências na busca era igual ao número de trabalhos listados.

Apesar disso, na leitura do título de cada trabalho foi possível perceber títulos repetidos, e nesses casos, a contagem era atualizada considerando esse erro.

Nos SNEF 2009, SNEF 2011, SNEF 2013, EPEF 2010, EPEF $2011^{1}$ e EPEF 2012 o procedimento para contagem do total de trabalhos foi realizado manualmente

\footnotetext{
${ }^{1}$ Apesar de o EPEF ser um evento bianual, em 2011 ocorreu o Encontro de Física, que integrou grandes eventos da área da pesquisa em Física (como por exemplo, Matéria Condensada, Física Nuclear, etc.) e da área de Ensino de Física. Por conta
} 
através dos links disponíveis nas programações dos eventos. Por exemplo, em uma comunicação oral é possível abrir um link com os campos temáticos existentes naquela sessão, e para cada campo abre-se outro link com os títulos dos trabalhos (e link para o trabalho completo) e palavras-chave. O mesmo procedimento ocorre para as sessões de pôsteres.

No EPEF de 2011 muitos trabalhos constavam na programação sem um link para acesso do trabalho completo. Para efeitos de contagem, nesse ano todos os trabalhos listados na programação final (que por conta disso, foram aceitos) foram contabilizados, inclusive os sem links. Outra característica do EPEF 2011 foi a realização de sessões coordenadas com discussões de trabalhos com a mesma temática. Nesse caso, no link de cada sessão os trabalhos eram apresentados em um mesmo arquivo, mas foram contabilizados separadamente na contagem.

\subsection{Trabalhos selecionados}

Após a análise dos eventos ocorridos e os trabalhos publicados seguindo os critérios descritos anteriormente, os resultados encontrados estão explicitados na tabela abaixo:

Quadro I: Quantidade de trabalhos apresentados nos SNEFs e EPEFs na última década

\begin{tabular}{|l|l|l|l|}
\hline Ano & Total de trabalhos no evento & Trabalhos selecionados & Porcentagem \\
\hline SNEF 2003 & 391 & 1 & $0,26 \%$ \\
\hline EPEF 2004 & 147 & 1 & $0,68 \%$ \\
\hline SNEF 2005 & 461 & 3 & $0,65 \%$ \\
\hline EPEF 2006 & 108 & 2 & $1,85 \%$ \\
\hline SNEF 2007 & 298 & 3 & $1,01 \%$ \\
\hline EPEF 2008 & 163 & 3 & $1,84 \%$ \\
\hline SNEF 2009 & 410 & 5 & $1,22 \%$ \\
\hline EPEF 2010 & 149 & 3 & $2,01 \%$ \\
\hline
\end{tabular}

disso, para a apresentação no EPEF 2011 era necessário submeter somente um resumo expandido do trabalho, com ênfase nas apresentações de pôsteres.

2 Em SALEM (2009) é apresentada uma sistematização dos SNEFs de 1970 a 2007 com dados estatísticos, como por exemplo, o total de trabalhos nos eventos. De acordo com essa pesquisa em 2003 foram 392 trabalhos e em 2005 foram 458 trabalhos. No entanto, SALEM ressalta que os resultados estão incertos, pois existem discrepâncias na contagem se considerar a listagem de trabalhos, a ata ou a programação. Por isso, optou-se em manter o total contabilizado seguindo a metodologia de busca descrita anteriormente. 


\begin{tabular}{|l|l|l|l|} 
EPEF 2011 & 276 & 5 & $1,81 \%$ \\
\hline SNEF 2011 & 417 & 3 & $0,72 \%$ \\
\hline EPEF 2012 & 199 & 1 & $0,50 \%$ \\
\hline SNEF 2013 & 600 & 6 & $1,0 \%$ \\
\hline Total & 3619 & 36 & $0,99 \%$ \\
\hline
\end{tabular}

Na Tabela I, para cada ano de ocorrência do evento é apresentado o número total de trabalhos, o número de trabalhos selecionados que estão relacionados com a temática "relação da física com a matemática" e a porcentagem que esses trabalhos selecionados representam em relação ao número total dos trabalhos do evento.

Através desses resultados é possível perceber que a porcentagem de trabalhos apresentados que visam discutir, apresentar e/ou pesquisar as relações entre a física e a matemática é de aproximadamente $1 \%$ se considerarmos o total de trabalhos na última década.

Comparando os dois eventos, o EPEF é o evento que mais apresentou trabalhos com a temática, com $1,4 \%$ do total de trabalhos publicados. No SNEF, na última década, $0,78 \%$ dos trabalhos apresentados exploraram o tema.

Tendo em vista que o SNEF é um evento que facilita a interação de um grande número de pesquisadores e professores e por isso é um espaço que permite ampliar as discussões que são importantes e relevantes para o ensino e aprendizagem de física, a quantidade de trabalhos com essa temática - que é de suma importância - é pequena.

Para ter uma visão geral dos trabalhos que foram selecionados nessa revisão, construiu-se a tabela abaixo com o título e autores de cada trabalho e um código de referência que será utilizado nesse capítulo:

Quadro II: Trabalhos analisados e códigos de referência

\begin{tabular}{|c|c|c|l|l|l|}
\hline Código & & & \multicolumn{1}{|c|}{ Trabalho } & \multicolumn{1}{c|}{ Autores } \\
\hline 1 & SNEF 2003 & $\begin{array}{l}\text { Introdução ao ensino da física: } \\
\text { uma abordagem fenomenológica } \\
\text { ou matemática? }\end{array}$ & $\begin{array}{l}\text { Eloneid Felipe Nobre, Ricardo Sávio } \\
\text { Teixeira Moretzsohn, Vagner Dieb, Alda } \\
\text { Cintra. }\end{array}$ \\
\hline
\end{tabular}




\begin{tabular}{|c|c|c|c|c|}
\hline 2 & EPEF & 2004 & $\begin{array}{l}\text { Os raciocínios hipotéticos - } \\
\text { dedutivos e proporcionais nas } \\
\text { aulas de ciência. }\end{array}$ & $\begin{array}{l}\text { Rogério José Locatelli \& Anna Maria } \\
\text { Pessoa de Carvalho }\end{array}$ \\
\hline 3 & SNEF & 2005 & $\begin{array}{l}\text { Contribuições do cálculo à } \\
\text { aprendizagem da hidrostática }\end{array}$ & Luiz Claudio Pereira \\
\hline 4 & SNEF & 2005 & $\begin{array}{l}\text { A relevância da metrologia no } \\
\text { ensino médio }\end{array}$ & Jailson Alves da Silva, Adir Moisés Luiz. \\
\hline 5 & SNEF & 2005 & $\begin{array}{l}\text { Os raciocínios hipotético-dedutivo } \\
\text { e proporcional nas aulas de } \\
\text { ciências (idem EPEF) }\end{array}$ & $\begin{array}{l}\text { Rogério José Locatelli, Anna Maria } \\
\text { Pessoa de Carvalho. }\end{array}$ \\
\hline 6 & EPEF & 2006 & $\begin{array}{l}\text { Iniciando os estudantes na } \\
\text { matemática da física através de } \\
\text { aulas experimentais investigativas }\end{array}$ & $\begin{array}{l}\text { Alex Bellucco do Carmo \& Anna Maria } \\
\text { Pessoa de Carvalho }\end{array}$ \\
\hline 7 & EPEF & 2006 & $\begin{array}{l}\text { De los números al álgebra en } \\
\text { cinemática elemental: análisis de } \\
\text { un cuestionario }\end{array}$ & $\begin{array}{l}\text { Silvia Margarita Pérez y m. Celia Dibar } \\
\text { Ure. }\end{array}$ \\
\hline 8 & SNEF & 2007 & $\begin{array}{l}\text { A falta de conhecimento de } \\
\text { matemática atrapalha o o } \\
\text { aprendizado de física de alunos de } \\
\text { ensino médio? }\end{array}$ & $\begin{array}{l}\text { Ana Roberta Paulino, lgo Paulino, } \\
\text { Patricio Felix. }\end{array}$ \\
\hline 9 & SNEF & 2007 & $\begin{array}{l}\text { Modelagem matemática e } \text { a } \\
\text { atividade experimental como } \\
\text { um modelo de integração no } \\
\text { ensino de física }\end{array}$ & $\begin{array}{l}\text { Wagner Morrone, Cláudia de Oliveira } \\
\text { Lozada, Luiz Henrique Amaral, Mauro } \\
\text { Sérgio Teixeira de Araújo. }\end{array}$ \\
\hline 10 & SNEF & 2007 & $\begin{array}{l}\text { O OA - gangorra interativa e a } \\
\text { interdisciplinaridade matemática- } \\
\text { física }\end{array}$ & $\begin{array}{l}\text { Gilvandenys Leite Sales, Eliana Moreira } \\
\text { de Oliveira, José Aires de Castro Filho, } \\
\text { Raquel Santiago, laécio Nobre de } \\
\text { Macedo, Daniel Siqueira. }\end{array}$ \\
\hline 11 & EPEF & 2008 & $\begin{array}{l}\text { Formalização matemática x física } \\
\text { moderna no ensino médio: é } \\
\text { possível solucionar esse impasse? }\end{array}$ & Ricardo Karam \& Maurício Pietrocola \\
\hline 12 & EPEF & 2008 & $\begin{array}{l}\text { Um estudo de caso relacionando } \\
\text { formação de professores, } \\
\text { modelagem matemática e } \\
\text { resolução de problemas no ensino } \\
\text { de física. }\end{array}$ & $\begin{array}{l}\text { Cláudia de Oliveira Lozada \&Nadja s. } \\
\text { Magalhães }\end{array}$ \\
\hline 13 & EPEF & 2008 & $\begin{array}{l}\text { Construção de } \text { gráficos em } \\
\text { atividade de investigação: } \\
\text { microanálise de aulas de física }\end{array}$ & $\begin{array}{l}\text { Josimeire Júlio, Arnaldo vaz, a. Tarciso } \\
\text { Borges. }\end{array}$ \\
\hline 14 & SNEF & 2009 & $\begin{array}{l}\text { Resolução de problemas e o papel } \\
\text { da matemática como } \\
\text { estruturante do pensamento físico }\end{array}$ & Ricardo Karam, Maurício Pietrocola. \\
\hline 15 & SNEF & 2009 & $\begin{array}{llr}\text { A importância da } & \text { modelagem } \\
\text { matemática na } & \text { formação } \\
\text { de professores de física } & \end{array}$ & $\begin{array}{l}\text { Cláudia de Oliveira Lozada, Nadja Simão } \\
\text { Magalhães. }\end{array}$ \\
\hline 16 & SNEF & 2009 & $\begin{array}{l}\text { Ensino de física e matemática: } \\
\text { diálogos possíveis }\end{array}$ & $\begin{array}{l}\text { Geraldo Bull da Silva Júnior, Eliane } \\
\text { Scheid Gazire. }\end{array}$ \\
\hline 17 & SNEF & 2009 & $\begin{array}{l}\text { Um exemplo de contribuição do } \\
\text { ensino de física para o ensino de } \\
\text { matemática }\end{array}$ & $\begin{array}{l}\text { Ingrid Ribeiro da Rocha, Helder de } \\
\text { Figueiredo e Paula. }\end{array}$ \\
\hline
\end{tabular}




\begin{tabular}{|c|c|c|c|c|}
\hline 18 & SNEF & 2009 & $\begin{array}{llll}\text { Aspectos físico e } & \text { matemático no } \\
\text { ensino do } & \text { conceito } & \text { de } \\
\text { campo elétrico } & & \end{array}$ & $\begin{array}{l}\text { Otto Henrique Martins da Silva, Nilson } \\
\text { Marcos Dias Garcia. }\end{array}$ \\
\hline 19 & EPEF & 2010 & $\begin{array}{l}\text { Dificuldades semióticas na } \\
\text { construção de gráficos cartesianos } \\
\text { de cinemática }\end{array}$ & $\begin{array}{l}\text { Paulo Sérgio de Camargo filho, Carlos } \\
\text { Eduardo laburú. }\end{array}$ \\
\hline 20 & EPEF & 2010 & $\begin{array}{l}\text { Relações entre conhecimento } \\
\text { conceitual, domínio de técnicas } \\
\text { matemáticas e visões do papel da } \\
\text { matemática na física e na } \\
\text { resolução de problemas sobre a } \\
\text { primeira lei da termodinâmica. }\end{array}$ & $\begin{array}{l}\text { Ana Raquel Pereira de Ataíde, Ileana } \\
\text { Maria Greca. }\end{array}$ \\
\hline 21 & EPEF & 2010 & $\begin{array}{l}\text { As equações matemáticas no } \\
\text { ensino de física: uma análise da } \\
\text { exposição didática dos conteúdos } \\
\text { nos livros textos de física }\end{array}$ & $\begin{array}{l}\text { Antonio Jorge Sena dos Anjos, Concesa } \\
\text { Caballero, Marco Antonio Moreira. }\end{array}$ \\
\hline 22 & EPEF & 2011 & $\begin{array}{l}\text { A modelagem matemática aplicada } \\
\text { no estudo experimental de } \\
\text { fenômenos físicos: uma } \\
\text { possibilidade para o ensino de } \\
\text { física }\end{array}$ & $\begin{array}{l}\text { Luís da Silva Campos, Mauro Sérgio } \\
\text { Teixeira de Araújo. }\end{array}$ \\
\hline 23 & EPEF & 2011 & $\begin{array}{l}\text { Papel do pensamento narrativo e } \\
\text { do pensamento lógico-matemático } \\
\text { no desenvolvimento científico: uma } \\
\text { análise epistemológica através do } \\
\text { inicio da eletrodinâmica }\end{array}$ & Ivã Gurgel, Mauricio Pietrocola. \\
\hline 24 & EPEF & 2011 & $\begin{array}{l}\text { Modelos, matemática e física na } \\
\text { história da ciência e no ensino: os } \\
\text { casos da luz como onda e como } \\
\text { onda eletromagnética. }\end{array}$ & Sonia Krapas \\
\hline 25 & EPEF & 2011 & $\begin{array}{l}\text { Abordagem do caráter estruturante } \\
\text { da matemática em aulas de } \\
\text { eletromagnetismo }\end{array}$ & $\begin{array}{l}\text { Ricardo Karam, Gesche Pospiech, } \\
\text { Maurício Pietrocola. }\end{array}$ \\
\hline 26 & EPEF & 2011 & $\begin{array}{l}\text { As equações matemáticas no } \\
\text { ensino de física: o que pensam os } \\
\text { professores }\end{array}$ & $\begin{array}{l}\text { Antonio Jorge s. Dos anjos, Concesa } \\
\text { Caballero, Marco Antonio Moreira. }\end{array}$ \\
\hline 27 & SNEF & 2011 & $\begin{array}{l}\text { A modelagem matemática e a } \\
\text { experimentação utilizadas como } \\
\text { recursos para a construção do } \\
\text { conhecimento em física }\end{array}$ & $\begin{array}{l}\text { Luís da Silva Campos, Mauro Sérgio } \\
\text { Teixeira de Ataújo. }\end{array}$ \\
\hline 28 & SNEF & 2011 & $\begin{array}{l}\text { Um estudo de caso sobre a } \\
\text { formação de professores } \\
\text { de física e a prática da modelagem } \\
\text { matemática aplicada ao ensino de } \\
\text { física }\end{array}$ & $\begin{array}{l}\text { Claudia de Oliveira Lozada, Nadja Simão } \\
\text { Magalhães. }\end{array}$ \\
\hline 29 & SNEF & 2011 & $\begin{array}{l}\text { Contribuições de Brahe, Kepler, } \\
\text { Newton e da matemática na } \\
\text { construção da lei da gravitação. }\end{array}$ & $\begin{array}{l}\text { Djalma Nunes da Silva, Jesuína Lopes } \\
\text { de Almeida Pacca. }\end{array}$ \\
\hline 30 & EPEF & 2012 & $\begin{array}{l}\text { Identificando os significados de } \\
\text { "matematização" num curso de } \\
\text { licenciatura em física }\end{array}$ & Diego Vizcaíno, Eduardo Terrazzan. \\
\hline
\end{tabular}




\begin{tabular}{|c|l|l|l|l|}
\hline 31 & SNEF & 2013 & $\begin{array}{l}\text { Análise do tratamento matemático } \\
\text { do movimento em livros didáticos } \\
\text { segundo olhares de aprendizagem, } \\
\text { curriculares epistemológicos. }\end{array}$ & $\begin{array}{l}\text { Gabriel Bernardes Justiniano, Alexandre } \\
\text { Sousa de Jesus, Luís Gonzaga } \\
\text { Roversi Genovez }\end{array}$ \\
\hline 32 & SNEF & 2013 & $\begin{array}{l}\text { A relevância das linguagens } \\
\text { matemática e comum na } \\
\text { produção e ensino da física }\end{array}$ & Maria José P. M. de Almeida. \\
\hline 33 & SNEF & 2013 & $\begin{array}{l}\text { Os licenciandos em física e as } \\
\text { relações que os levaram a cursar a a } \\
\text { licenciatura em física: a } \\
\text { matemática e aísica escolar }\end{array}$ & Larissa Dias Feitosa \\
\hline 35 & SNEF & 2013 & $\begin{array}{l}\text { Proposta didática e procedimentos } \\
\text { para a superação de dificuldades } \\
\text { matemáticas para introdução da } \\
\text { física no ensino fundamental }\end{array}$ & $\begin{array}{l}\text { Sheila Corrêa, Alice dos Santos, Rodrigo } \\
\text { Franco, Tatiane Feijó, Sônia Ornelas, } \\
\text { Pedro Dorneles, Edson M. Kakuno. }\end{array}$ \\
\hline 36 & SNEF 2013 & $\begin{array}{l}\text { Revisitando a prática de resolução } \\
\text { de lista de exercícios: linguagem } \\
\text { matemática, linguagem verbal e } \\
\text { significação física em ambiente } \\
\text { virtual de aprendizagem. }\end{array}$ & $\begin{array}{l}\text { Henrique César da Silva, Keilli Franciane } \\
\text { da Luz. }\end{array}$ \\
\hline $\begin{array}{l}\text { A complementaridade das } \\
\text { linguagens narrativas e matemática } \\
\text { no contexto da gestação da } \\
\text { relatividade geral }\end{array}$ & Danilo Cardoso, Ivã Gurgel. \\
\hline
\end{tabular}

\section{3 Ênfases dos trabalhos analisados}

Nesses trabalhos, foi possível identificar se eles possuíam ou não uma ênfase explícita no ensino regular (ensino fundamental, médio e/ou superior) ou somente uma reflexão da relação da física com a matemática na construção da própria ciência e do ensino em geral dela. A partir dessa análise, os resultados foram sintetizados na tabela III:

\section{Quadro III: Ênfases dos trabalhos apresentados nos eventos na última década}

\begin{tabular}{|l|c|l|}
\hline $\begin{array}{l}\text { Énfases dos trabalhos } \\
\text { apresentados nos eventos } \\
\text { na última década com a } \\
\text { temática "relação da física } \\
\text { com a matemática". }\end{array}$ & $\begin{array}{l}\text { Trabalhos com esse } \\
\text { enfoque (códigos) }\end{array}$ & $\begin{array}{l}\text { Porcentagem em } \\
\text { relação ao total de } \\
\text { trabalhos }\end{array}$ \\
\hline Ensino Fundamental & $1,2,5,10$ e 34 & $13,9 \%$ \\
\hline Ensino Médio & $\begin{array}{c}4,6,8,9,11,13,14,16, \\
17,18,21,22,26 \text { e 31 }\end{array}$ \\
\hline Ensino Superior & $3,7,12,15,19,20,24$, & $38,9 \%$ \\
\hline
\end{tabular}




\begin{tabular}{|lc|c|c|}
\hline & $25,30,27,28,33$ e 35 & \\
\hline $\begin{array}{l}\text { Reflexão histórica e/ou } \\
\text { epistemológica }\end{array}$ & $23,29,32$ e 36 & $11,1 \%$ \\
\hline
\end{tabular}

Observando os trabalhos analisados, percebe-se que na última década a temática "relação da física com a matemática" foi mais discutida em propostas de ensinos e estudos de casos voltados ao ensino médio (38,9\%), seguido de propostas e estudos de casos no ensino superior (36,1\%). Apesar de no Ensino Fundamental não constar uma disciplina específica de física, e sim a disciplina Ciências que abarca biologia e conceitos de física e química, existem trabalhos que exploram a relação da matemática com a física nesse nível de ensino (13,9\%). No geral, esses trabalhos investigam a dificuldade da inserção da física no ensino fundamental juntamente com a matemática, principalmente no último ano do ensino fundamental II (nono ano), quando alguns conceitos e formulações matemáticas são apresentados.

Também foi possível detectar trabalhos que não trazem propostas de ensino e/ou estudos de casos específicos (11,1\%), mas trazem uma reflexão histórica, filosófica e/ou epistemológica da relação da física com a matemática, seja na construção da própria ciência ou no ensino dela.

É interessante notar que as pesquisas se concentram mais no nível médio e superior, que são níveis que os alunos já tiveram algum contato anterior com a física, no médio através da conceitualização de fenômenos comuns do dia a dia no ensino fundamental (formação do arco-íris, imãs e o magnetismo etc.) e no superior através das aulas de física do ensino médio.

\subsection{Síntese dos campos temáticos mais explorados nos eventos}

Considerando os dois eventos na área de Ensino de Física na última década foram revisados um total de 3619 trabalhos, resultando em 36 publicações que tem como temática a relação da física com a matemática. Nos trabalhos selecionados é possível observar semelhanças no enfoque dado, já que é admissível explorar a relação da física com a matemática com óticas e perspectivas diferentes. Após a leitura minuciosa de cada trabalho, foi possível dividi-los em categorias temáticas, que são explicitadas abaixo: 
A) A relação da física com a matemática e a resolução de problemas: Nessa categoria foram considerados os trabalhos que tinham como plano de fundo a resolução de problemas. Foram registrados, por exemplo, trabalhos que discursavam sobre a matemática como linguagem, suporte e fundamentação para a resolução de problemas em física. $O$ trabalho de KARAM (2009), intitulado: "Resolução de problemas e o papel da matemática como estruturante do pensamento físico" é um exemplo publicação que foi classificado nessa categoria. Nesse trabalho, é analisado o uso que os estudantes fazem da matemática ao resolverem problemas de física, com uma proposta de classificação que permite distinguir habilidades técnicas - aquelas relacionadas ao domínio instrumental de algoritmos, regras, fórmulas, gráficos, equações - das habilidades estruturantes - associadas à capacidade de se fazer um uso organizacional da matemática na física. Outros trabalhos versavam sobre os conhecimentos matemáticos necessários para resolver problemas em física, ou seja, estudos de caso que envolvem a resolução de problemas. Um exemplo de trabalho classificado nessa categoria foi: "Os raciocínios hipotéticos - dedutivos e proporcionais nas aulas de ciências LOCATELLI (2004)". Nessa publicação, foi feita uma análise documental dos discursos dos alunos do Ensino Fundamental durante a resolução dos problemas de conhecimento físico. Na pesquisa, percebeu-se que o padrão de raciocínio hipotético dedutivo - "se... então... portanto..." - vai sendo sistematizado pelos alunos ao mesmo tempo em que também eles vão construindo o raciocínio de proporções, que é a base da linguagem matemática nas ciências. Outro tipo de trabalho classificado nessa categoria foram os trabalhos que tinham como principal objetivo explanar sobre a resolução de problemas através da modelagem matemática. Um exemplo é o trabalho: "Um estudo de caso relacionando formação de professores, modelagem matemática e resolução de problemas no ensino de física - LOZADA (2008)". Nessa publicação, foram analisadas as dificuldades que os alunos do Ensino Médio possuem para realizar a Modelagem Matemática na resolução de problemas de Física. Um aspecto apontado na pesquisa diz respeito à propositura de problemas numa 
dimensão investigativa: ela faz que os alunos elaborem seus próprios modelos matemáticos e desvinculem-se da "cultura dos problemas tipo" e da "aplicação de fórmulas", permitindo a autonomia de pensamento e de ação, fomentando o educar pela pesquisa.

B) O conhecimento matemático e a aprendizagem em física: nessa categoria foram considerados os trabalhos que explanavam a respeito da importância dos conhecimentos matemáticos no ensino e aprendizagem da física, sem explorar explicitamente a resolução de problemas, e sim o contexto educacional. Um exemplo de trabalho classificado nessa categoria foi o de PAULINO (2007), intitulado: " $A$ falta de conhecimento de matemática atrapalha o aprendizado de física de alunos de ensino médio?". Nessa publicação, com o objetivo de investigar quais são as principais dificuldades que os alunos do ensino médio encontram no processo ensino-aprendizagem de física, foi realizada uma pesquisa com alunos de escolas públicas com uma série de perguntas que questionaram estes alunos a respeito da sua opinião sobre as disciplinas de física, matemática e língua portuguesa e sobre as possíveis relações que eles consideram existir entre física e matemática. Como resultado, a respeito da matemática boa parte dos alunos a considera importante para a física e defendem que estas duas disciplinas estão fortemente interligadas, no entanto, a grande maioria não consegue fazer associações dos problemas de física com a ferramenta matemática necessária para sua solução.

C) Experimentação e modelagem matemática: nessa categoria foram agrupados os trabalhos que relacionavam explicitamente a experimentação em física - real ou virtual - e a modelagem matemática, como por exemplo, o trabalho: "A modelagem matemática $e$ a experimentação utilizadas como recursos para a construção do conhecimento em física - CAMPOS (2011)". Nessa publicação, os pesquisadores introduziram atividades experimentais estruturadas com roteiros fechados e migraram gradativamente para atividades semiestruturadas. Como principais resultados, foi verificado que a 
associação dos conceitos de Modelagem Matemática com a Experimentação voltada para o Ensino de Física possibilitou a construção e representação das relações matemáticas que envolveram algumas grandezas de cinemática e de dinâmica, além de aprimorar as habilidades de realizar medidas, escolher adequadamente os instrumentos e analisar os dados obtidos.

D) Relações entre o Ensino de Matemática e o Ensino de Física Interdisciplinaridade: nessa categoria estão os trabalhos que discutem as possíveis articulações entre as duas áreas de ensino, como por exemplo, o trabalho: "Ensino de física e matemática: diálogos possíveis -GAZIRE (2009)". Essa publicação teve o objetivo de buscar formas de gerar inovações no pensar e agir em Educação na área de Ciências e Matemática. Na pesquisa, são levantadas articulações de saberes entre a Cinemática e a Função Afim (1ำ Grau), que pode ser utilizada para descrever fenômenos e resolver problemas da Física e auxiliar o ensino de matemática. Verificou-se também no trabalho a possibilidade de estabelecer redes entre os ensinos dessas duas disciplinas como elementos articuladores de saberes.

E) A matemática na construção de um conceito físico - análise histórica e/ou epistemológica: nessa categoria foram inseridos os trabalhos que discursavam a respeito do papel e das funções da matemática na construção histórica do conhecimento físico, como por exemplo, o trabalho: "O papel do pensamento narrativo e do pensamento lógicomatemático no desenvolvimento científico: uma análise epistemológica através do inicio da eletrodinâmica - GURGEL (2011)". Nesse trabalho, é discutido o papel do pensamento narrativo e sua relação com 0 pensamento lógico-matemático na elaboração da ciência, de forma a mostrar a complementariedade nestas formas de pensar. Para isso, foram analisadas em uma perspectiva histórico-epistemológica, as obras de André-Marie Ampère, com o intuito de demonstrar uma possível relação 
nestas formas de pensar no desenvolvimento da Física, neste caso, a eletrodinâmica.

F) Papel da matemática na física - linguagem e estrutura: nessa categoria foram classificados os trabalhos que realizavam uma discussão teórica a respeito da matemática atuando como linguagem e/ou estrutura em um contexto geral da Física. Um exemplo de trabalho classificado nessa categoria é: "A RELEVÂNCIA DAS LINGUAGENS MATEMÁTICA E COMUM NA PRODUÇÃO E ENSINO DA FÍSICA - ALMEIDA (2013)". Nele, a partir de noções como a de formação discursiva e de reflexões de cientistas como Heisenberg, Einstein e Infeld, e de sociólogos como Terry Eagleton são discutidos os papeis da linguagem comum e matemática na produção e ensino da física. Dentre as reflexões é destacada a impossibilidade de tradução completa da linguagem matemática para a linguagem comum, discutindo-se também o papel da linguagem comum na possibilidade de acesso à cultura científica.

O resultado dessa análise está representado no gráfico abaixo. Cada letra representa a subcategoria que foi descrita anteriormente:

\section{Temáticas dos trabalhos selecionados}

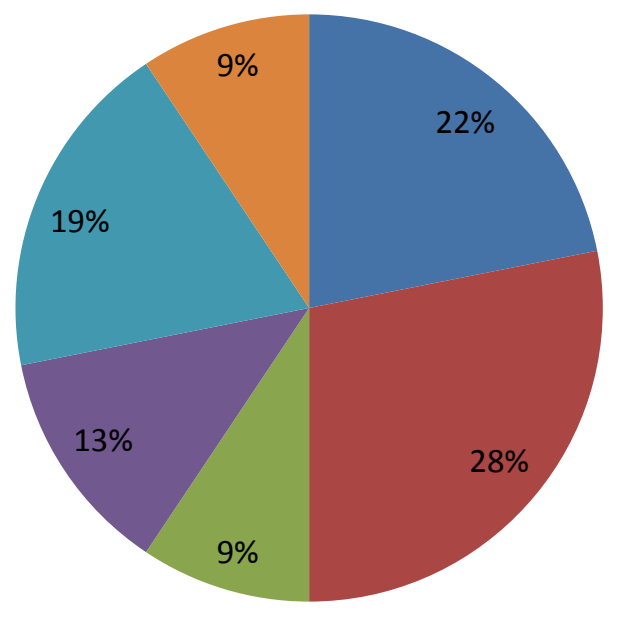


Pela análise do gráfico I, é possível perceber que os trabalhos publicados e apresentados nos dois principais eventos na área de Ensino de Física têm como temática principal a subcategoria $\mathbf{B}$ (o conhecimento matemático e a aprendizagem em física). Nessa subcategoria destacam-se a relação da defasagem nos conhecimentos matemáticos e a aprendizagem de física, seja no nível básico, médio ou superior.

A segunda subcategoria mais frequente na análise foi a $\mathbf{A}$ (a relação da física com a matemática e a resolução de problemas), ressaltando que a resolução de problemas no ensino de física é uma questão altamente relevante e discutida na área de ensino.

A terceira subcategoria mais frequente foi a $\mathbf{E}$ (a matemática na construção de um conceito físico - análise histórica e/ou epistemológica), destacando-se trabalhos que explicitam a importância da matemática na construção da física, principalmente na física moderna e contemporânea. A temática Interdisciplinaridade (D), a experimentação e modelagem matemática $(\mathbf{C})$ e a discussão do papel da matemática na física - linguagem e estrutura (F) foram respectivamente outros enfoques frequentes.

Percebe-se também que metade dos trabalhos publicados na última década discursa a relação da física com a matemática ou sobre a ótica da resolução de problemas ou sobre quanto o conhecimento matemático (ou a falta dele) interferem no aprendizado da física. Observando a ordem cronológica dos eventos e os trabalhos neles apresentados, percebe-se também que a discussão histórica, filosófica e/ou epistemológica da relação da física com a matemática tomou coro nos últimos anos (eventos) analisados, com mais trabalhos sendo apresentados e discutidos nessa área.

Essa análise cronológica realizada até o momento é importante para entender quais discussões e pesquisas já foram realizadas na área de ensino sobre a relação da física com a matemática e quais questionamentos elas geram para futuros trabalhos. 


\section{Capítulo 2}

\section{Relação da física com a matemática: caráter técnico e caráter estrutural}

Discutir o papel da matemática na física pode ser análogo a discutir o papel da gramática na língua portuguesa: são permitidas óticas e atuações diferentes, dependendo do contexto. Usamos a matemática na física em diversas situações, seja na elaboração de cálculos, resolução de equações, interpretação física de um sinal, de um gráfico ou ainda no raciocínio lógico matemático necessário em diversos problemas.

Um dos principais autores que discorre sobre as relações entre a física e a matemática na Física é PATY. Ele cita, por exemplo, que em algumas das atuações, a matemática pode ser utilizada como instrumento. PATY (1995) comenta:

Em sua utilização na física, a matemática pode ser concebida como um instrumento que constrói, ou que isola estruturas. PATY (1995: 236)

Utilizamos a matemática com essa finalidade, por exemplo, ao fazer medições, na escolha de variáveis etc. e também como "esqueleto" das estruturas físicas. STEWART (2013) também traz uma visão "instrumental" ao discorrer sobre o uso do cálculo na física:

Como a chave de fenda, o cálculo é simplesmente uma ferramenta indispensável no arsenal do engenheiro e do cientista. Mais do que qualquer outra técnica matemática, ele criou o mundo moderno. STEWART (2013: 72)

De fato, o cálculo é tão importante para a Física que na formação de físicos e professores de física é essencial aprender essa "ferramenta" desde o início da graduação.

Mas para a matemática e a física, a instrumentação não é o único pilar que pode edificar a relação entre elas. Segundo POINCARÉ (2005), os objetivos da matemática e da física interpolam, extrapolando o caráter instrumental. Os outros 
objetivos (filosóficos e estéticos, citados pelo autor, por exemplo) que atuam em conformidade com a construção científica nos levam a questionar como a atuação da matemática pode ser encarada.

Ao utilizar a matemática como transmissora de mensagens da física, podemos pensar na matemática como linguagem. Em seu trabalho, ALMEIDA (1999) reconhece a matemática como linguagem por meio da qual a física se expressa, enxergando a linguagem matemática como uma metalinguagem constitutiva da física. Galileu Galilei também compreende que a "leitura do universo" ocorre através de uma linguagem matemática:

A filosofia encontra-se escrita neste grande livro que continuamente se abre perante nossos olhos (isto é, o universo), que não se pode compreender antes de entender a língua e conhecer os caracteres com os quais está escrito. Ele está escrito em língua matemática, os caracteres são triângulos, circunferências e outras figuras geométricas, sem cujos meios é impossível entender humanamente as palavras; sem eles nós vagamos perdidos dentro de um obscuro labirinto. GALILEU (1973: 119)

Também a respeito da linguagem e a matemática, Feynman (2000) complementa:

(...) a matemática não é apenas outra linguagem: é uma linguagem mais o raciocínio, é uma linguagem mais a lógica, é um instrumento para raciocinar. É, de fato, uma grande coleção de resultados provenientes de pensamentos e raciocínios cuidadosos. Ela permite relacionar um enunciado com outro.

BACHELARD (2010) discursa também a respeito das possibilidades que a matemática proporciona à física, essencialmente para a realidade física:

[...] a informação matemática nos dá mais que o real, ela nos dá o plano do possível, ultrapassa a experiência efetiva da coerência, nos entrega o compassível. Não se trata de uma coerência concreta, mas de uma coerência abstrata. BACHELARD (2010: 64) 
O autor enxerga na matemática sua natureza constitutiva da construção científica. Através da ideia de "obstáculo epistemológico", a matemática proporciona um conflito entre modos de ver o mundo, no caso de fenômenos físicos, e um novo modo de percebê-los, permitindo uma ruptura de um modo antigo de compreender e lidar com um fenômeno.

No entanto, PATY (1995), ressalta a ideia de que a matemática não pode ser exclusivamente responsável pela visualização da natureza física, uma vez que existe física além do plano matemático:

A realidade física não é esgotada por sua formulação matemática, e o real é mais rico que sua representação. PATY (1995: 280)

Em um dos seus trabalhos, resumidamente, o físico e filósofo PATY (1995) sintetiza os papéis que a matemática exerce na sua relação com a Física e os diversos níveis dessa relação:

As teorias físicas fazem intervir o uso da matemática em diversos níveis. No nível mais "fraco", ela representa apenas um instrumento externo, despojado de conteúdo físico: é o caso do cálculo, da escolha de variáveis ou de unidades que podem ser mudadas sem acarretar qualquer modificação da teoria física, como é também o caso das matrizes, da teoria das perturbações ... Essas teorias matemáticas seguem o jogo próprio, que é, evidentemente, necessário respeitar, no caso de utilização em Física. Mas elas são neutras, do ponto de vista físico, enquanto nenhuma carga semântica Ihes é outorgada. Ao contrário, no nível "mais forte", a matemática pode entrar na própria construção de um conceito físico (um exemplo disso é a velocidade, definida como $\mathrm{dx} / \mathrm{dt}$; é igualmente o caso das observáveis, definidas por seus operadores, em mecânica quântica) ou numa abstração geral de leis físicas erigida em princípio (ver, por exemplo, a enunciação do princípio da relatividade, ou da ação mínima, etc.). PATY (1995: 251)

Os níveis citados pelo autor (fraco e forte) podem estar presentes no ensino e aprendizagem de física, seja no ensino básico ou no ensino superior. 
Nesse breve resumo sobre as ideias de alguns autores a respeito da relação da física com a matemática, podemos compreender que o papel instrumental citado, por exemplo, por STEWART (2003) corresponde o que PATY (1995) classifica como nível fraco da relação entre a física e a matemática. Já a ideia da matemática como linguagem trazida, por exemplo, por ALMEIDA (1999), permite refletir a ideia da matemática na construção do conhecimento físico, citado por PATY (1995) como nível forte.

Em sua tese, KARAM (2012) discute com profundidade a relação da matemática com a física através de uma análise epistemológica densa e consistente, apresentando um resumo das principais ideias trazidas por diversos pesquisadores.

Ele traz em seu trabalho uma reflexão que dialoga com os "níveis" fraco e forte da relação da matemática com a física citados por PATY. Ele apresenta um quadro que sintetiza os aspectos da dualidade técnico-estrutural (PIETROCOLA, 2012) para analisar o uso da matemática no ensino de física:

\begin{tabular}{|c|c|}
\hline Caráter técnico/instrumental/procedimental & Caräter estrutural/relacional/organizacional \\
\hline $\begin{array}{l}\text { Usar uma fórmula para resolver problemas } \\
\text { quantitativos }\end{array}$ & $\begin{array}{l}\text { Demonstrar uma fórmula a partir de princípios } \\
\text { fisicos }\end{array}$ \\
\hline Como/quando uso essa equaçăo? & Por quê essa equação é assim? \\
\hline Pling-and-chug & Significado fisico de expressões matemáticas \\
\hline $\begin{array}{l}\text { Professor Alfa: Manipulação de algoritmos de } \\
\text { cálculo }\end{array}$ & Professor Beta: Foco na interpretação fisica \\
\hline $\begin{array}{l}\text { Professor Gama: Argumentos de autoridade, } \\
\text { regras prontas }\end{array}$ & Professor Delta: Consistência matemática \\
\hline Nível Fraco - descriçăo e comunicaçào & Nivel forte - conceituação e estrutura \\
\hline Ferramenta de cálculo & Instrumento de pensamento \\
\hline $\begin{array}{l}\text { Ler uma equação de maneira literal. Ex.: } \\
\text { Explicar } \Delta \mathrm{x}=\mathrm{v} \text {. } \Delta \mathrm{t} \text { como "deslocamento é } \\
\text { igual à velocidade vezes o intervalo de tempo }\end{array}$ & $\begin{array}{l}\text { Mostrar equivalência entre asserções físicas } \\
\text { aparentemente distintas (ex. lei da gravitação } \\
\text { universal e lei das áreas) }\end{array}$ \\
\hline Semelhanças superficiais & Analogias profundas \\
\hline
\end{tabular}

Quadro IV: Dualidade técnico-estrutural da física com a matemática (KARAM - 2012:58)

Como exemplo do caráter técnico do uso da matemática no ensino de física, se enquadram a resolução repetitiva de exercícios com a utilização da mesma fórmula com números diferentes e a utilização de regras matemáticas sem uma significação para essas regras. Já no uso da matemática no ensino de física como 
caráter estrutural podemos exemplificar com demonstrações matemáticas através do sentido físico conceitual do conteúdo, interpretações de resultados numéricos interpretação física de um sinal negativo no resultado, por exemplo - e utilização de comparações e analogias que permitem compreender e dar significado aos resultados numéricos ou equações matemáticas encontradas.

$\mathrm{Na}$ dissertação esses dois caráteres servirão de norte para o desenvolvimento da pesquisa realizada. 


\section{Capítulo 3}

\section{Metodologia no desenvolvimento da pesquisa}

Nesta pesquisa, a metodologia empregada consiste na pesquisa qualitativa, cujo método inicial de coleta de dados se dá através da análise documental (LÜDKE \& ANDRÉ, 1986), que consiste em ter os documentos selecionados como objeto de investigação e análise; seguindo etapas e procedimentos e organizando as informações a serem categorizadas e posteriormente analisadas, com o auxílio da elaboração de sínteses.

Podemos dividir a pesquisa em três etapas importantes:

- $1^{\mathrm{a}}$ etapa: consistiu em um estudo teórico da relação da matemática com a física, com leituras dos trabalhos já desenvolvidos, revisão bibliográfica e estudo de diversos autores que discutem o tema. Essa etapa teve como objetivo mapear as investigações e pesquisas realizadas que abordam a relação da física com a matemática e situar a pesquisa dentro desse campo, pautando-se em referenciais que fundamentam a pesquisa e a investigação realizada.

- $2^{2}$ etapa: consistiu em um estudo de caso das aulas de Fundamentos de Mecânica, disciplina do primeiro semestre de licenciatura em Física. Esse estudo teve o intuito de identificar relações entre a física e a matemática na apresentação dos conteúdos e conceitos e fazer uma análise e categorização dessas relações. O estudo de caso teve como objetivo ampliar os exemplos da relação da física com a matemática e expandir a discussão do tema para um caso concreto e específico, que é a introdução da Mecânica no ensino superior.

- $3^{a}$ etapa: sistematização dos resultados obtidos e a relação dos resultados com o estudo teórico realizado, objetivando a conclusão final do trabalho. Essa etapa consistiu na organização dos dados e análises obtidas e no delineamento da pesquisa realizada. Nessa fase, os dados, análises, referenciais e possíveis conclusões foram discutidas, testadas e lapidadas. 
Apesar de as etapas serem expostas linearmente, a realização de cada etapa está intimamente ligada às outras etapas. Podemos fazer uma analogia com um plano cartesiano tridimensional (Imagem II): a intersecção das ações realizadas em cada etapa gera um ponto, e através da construção de pontos e da ligação entre eles, construiu-se o produto da pesquisa.

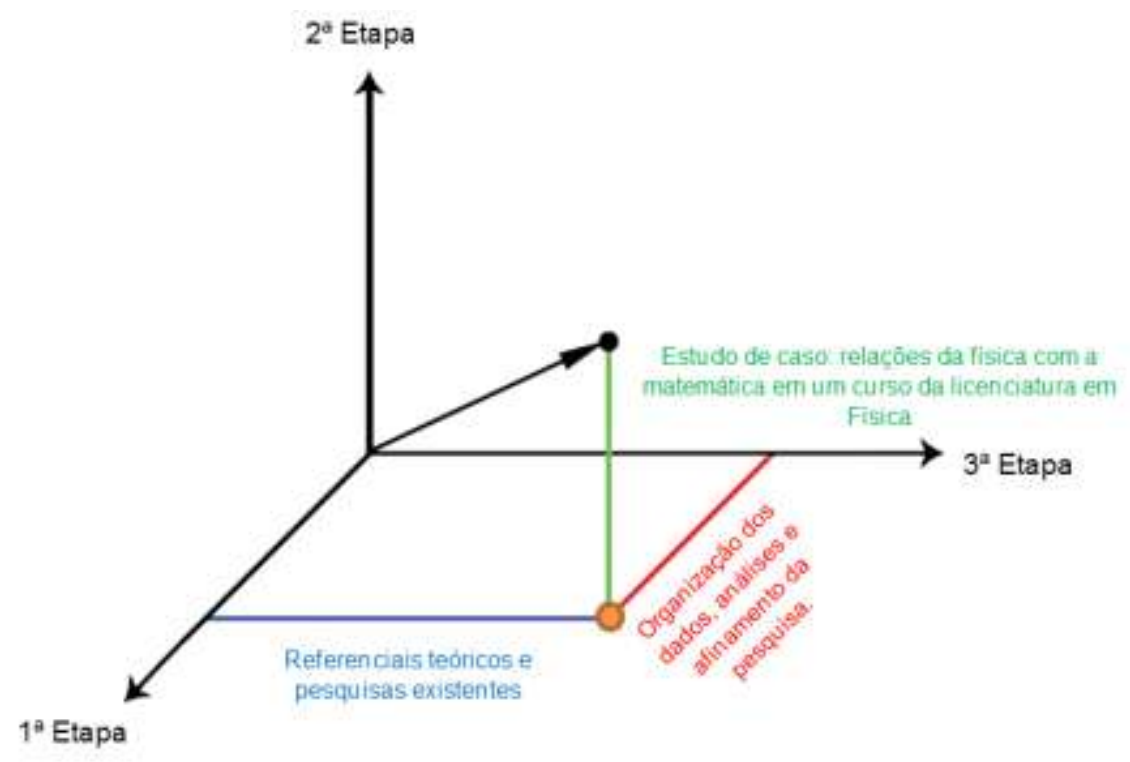

Imagem II: Etapas da pesquisa

\subsection{A escolha do estudo de caso}

Inicialmente, para dar concretude às discussões teóricas estudadas e às percepções levantadas nas reflexões sobre elas, optamos em pesquisar quais relações entre a física e a matemática poderiam estar presentes já no início da licenciatura em física, ou seja, no contato inicial que o estudante - futuro professor tem com a temática.

A escolha em olhar esse momento inicial se deu, principalmente, em função de já existirem pesquisas observando essa temática em cursos mais avançados de física (KARAM 2012, por exemplo) - com formalismos matemáticos mais complexos.

A escolha de um curso da licenciatura em detrimento a um curso do bacharelado em física se deu em função do número de pesquisas que discutem as abordagens matemáticas nas aulas de física do ensino médio, ou seja, olhar para a 
formação do futuro professor é importante, pois essa formação - que se inicia nos momentos iniciais da sua graduação - reflete na sua ação futura como docente.

Para essa análise, tínhamos três disciplinas de física sendo oferecidas no primeiro semestre da graduação: fundamentos de mecânica, ótica e introdução às medidas em física. Optamos por Fundamentos de Mecânica, pois os conteúdos de mecânica abrangem grande parte da grade curricular de física do ensino médio e entender como a relação da física com a matemática pode ser abordada nessas aulas pode auxiliar a compreensão, em futuras pesquisas, de como essa temática é inserida no ensino médio.

O curso de Fundamentos de Mecânica é semestral e é oferecido no primeiro semestre da licenciatura em física na Universidade de São Paulo em dois períodos, o diurno e o noturno. O curso possui 4 créditos, que equivalem a uma carga horária total de 60 horas, divididas em duas aulas semanais de 2 horas cada. No conteúdo programático do curso presente na grade horária da licenciatura, constam os objetivos e programa ${ }^{3}$

Objetivos: - Descrição do movimento de uma partícula. Análise de fenômenos da Mecânica. Articulação dos conceitos básicos envolvidos nas leis de Newton. Uso de simplificações e aproximações na explicação e na descrição dos fenômenos físicos. Representações gráficas de fenômenos.

Programa: grandezas físicas. Relações entre grandezas físicas. $\mathrm{O}$ que é uma lei física. O papel dos experimentos, das teorias, dos modelos e da Matemática na Física - com exemplos ilustrativos. Gênese da Mecânica. Galileu e a equivalência entre repouso e movimento retilíneo uniforme, independência dos movimentos em direções diferentes. Relatividade das variáveis cinemáticas e sistemas de referência inerciais. Força e interação. Ação e Reação: simultaneidade e igualdade de seus módulos e direções. Ação de contato e ação à distância. Relação entre força e aceleração; localização, composição e resultante de forças. Queda livre e movimento num campo de força constante. Condições de equilíbrio e

\footnotetext{
${ }^{3}$ Disponível em:

https://uspdigital.usp.br/jupiterweb/obterDisciplina?sgldis=4300151\&codcur=43031\& $\operatorname{codhab}=1$
} 
aplicações. Força de atrito estático, cinético e aplicações. Dinâmica do movimento circular e aplicações.

Quando a delimitação da pesquisa foi "desenhada" e optou-se em estudar as relações da física com a matemática em uma disciplina no primeiro semestre da licenciatura em física, o curso de fundamentos de mecânica já havia iniciado com quatro aulas ministradas, tanto no diurno quanto no noturno. Mesmo assim, pensando em fazer futuros recortes das informações coletadas, optou-se por iniciar o estudo de caso com as aulas sequenciais e procurar uma contextualização através do contato com os professores do conteúdo explicado até aquele momento.

\subsection{A observação e coleta de informações}

Primeiramente, por possuírem docentes diferentes e assim permitir informações distintas, optou-se em realizar o estudo de caso em duas turmas, que iremos chamar de Turma A e Turma B. Em comum, essas duas turmas possuíam em seu programa de curso a realização de provinhas (exercícios avaliativos que eram aplicados em uma parte da aula) e provas (mais extensas e com duração de uma aula).

A coleta de informações ocorreu da seguinte maneira: as aulas de fundamentos de mecânica foram assistidas (ou seja, não ocorreram interferências no andamento e planejamento de aulas), as explicações dos professores foram gravadas em áudio e todos os registros realizados na lousa foram copiados utilizando os mesmos códigos e padrões dos professores (equações, notações matemáticas, esboços de gráficos etc.).

Optou-se na gravação de áudio das explicações por alguns motivos: o primeiro, é que essa gravação é menos invasiva e discreta, permite que o professor fique mais à vontade em participar do estudo de caso, assim como os alunos a participarem da aula espontaneamente. O segundo motivo é que desde o início da pesquisa era interesse observar se e como os professores abordavam a relação da física com a matemática em suas falas, ou seja, nas suas verbalizações. As anotações das aulas permitem contextualizar as falas e visualizar os formalismos 
utilizados, mas as reflexões levantadas pelos professores assumem um ponto importante para a posterior análise.

Durante o processo de coleta de dados no estudo de caso, algumas aulas foram excluídas das gravações, como as aulas com aplicação de prova e provinhas. Com os prévios levantamentos das informações e obtenção de dados relevantes e suficientes para a pesquisa, optamos também em focar a análise nos conceitos iniciais da mecânica envolvendo o estudo do movimento - cinemática. Por isso, as aulas finais do curso de fundamentos de mecânica não foram gravadas.

Efetuando esses recortes, organizamos informações de um total de 11 aulas com duas horas cada (22 horas no total), sendo seis aulas da Turma A e cinco aulas da Turma B. O resumo destas aulas com seus respectivos códigos identificadores está presente no anexo desse trabalho. 


\section{Capítulo 4}

\section{Representação matemática em um curso de licenciatura em física}

Ao ensinar física, os professores e materiais didáticos se utilizam de códigos, símbolos e letras para representar grandezas físicas e/ou significados físicos. Por exemplo, é comum no estudo do movimento a posição de um corpo ser representada por uma letra $S$ ou uma letra $P$. Em algumas situações é de praxe os físicos analisarem se as grandezas utilizadas são escalares ou vetoriais, ou ainda escolherem o sistema de coordenadas mais adequado à situação estudada.

Para analisar o desenvolvimento das aulas e como a representação e signos matemáticos são apresentados na introdução à Mecânica na graduação, especificamente, na licenciatura em Física da USP (Universidade de São Paulo) foram extraídos das aulas assistidas os principais excertos que apresentam frases, imagens e raciocínios que servem de pano de fundo para explorar a relação da física com a matemática.

As aulas de Fundamentos de Mecânica nas duas turmas tiveram gravação de áudio e registro das anotações feitas pelo professor na lousa. Na descrição das aulas apresentada nesse capítulo, foram transcritas parcialmente as falas do professor na explicação do conteúdo (foram excluídas as falas que não estão relacionadas com a aula ou com o conceito explicado) e reproduzidas as imagens e cálculos que foram realizadas na lousa durante a explicação. As imagens originais copiadas durante as aulas (esboço de gráficos, por exemplo) foram refeitas para melhor organização e qualidade na transcrição das aulas. Os cálculos, fórmulas e resolução de exercícios foram digitados também com esse mesmo propósito. Nos episódios, as falas dos professores estão indicadas em itálico e a relação dessas falas com gráficos e equações estão indicadas com flechas direcionadas. A contextualização das aulas e os comentários sobre as representações matemáticas presentes (análise) também estão descritas intercaladas nos episódios. Os episódios estão expostos no capítulo em ordem temporal e por turma. 


\subsection{Turma $A$}

As aulas assistidas na Turma A tinham como principal caraterística a exposição teórica na lousa do conteúdo (com equações, esboços de gráficos etc.) e resolução ("correção") de exercícios selecionados pelo professor. Nessas aulas, a apresentação do conteúdo era contínua (ou seja, não havia tempo destinado ao trabalho exclusivo dos alunos, como tempo para resolver exercícios em aula). Abaixo apresentamos uma tabela que organiza os episódios da turma A que serão apresentados na sequência:

\begin{tabular}{|c|l|}
\hline Episódios & \multicolumn{1}{|c|}{ Conteúdos } \\
\hline I & $\begin{array}{l}\text {-Início do estudo da velocidade instantânea e aceleração instantânea } \\
\text { para o movimento unidimensional; Interpretação geométrica de um } \\
\text { gráfico; Velocidade média; Revisão de conceitos matemáticos: o que é } \\
\text { limite? O que é derivada? Como derivar polinômios? }\end{array}$ \\
\hline II & $\begin{array}{l}\text { grandeza vetorial e escalar; Revisão sobre vetores: o que são, como } \\
\text { fazer projeção etc. }\end{array}$ \\
\hline III & $\begin{array}{l}\text { Aplicações do MRUV; Equação da trajetória e Resolução comentada de } \\
\text { exercícios. }\end{array}$ \\
\hline IV & $\begin{array}{l}\text { lançamento oblíquo); Movimento circular uniforme; Diferentes } \\
\text { descrições: cartesiano e coordenadas polares e Exemplos de MCU. }\end{array}$ \\
\hline VI & $\begin{array}{l}\text { - Movimento circular; Formas vetoriais, sistema de coordenadas polares } \\
\text { e movimento circular arbitrário. }\end{array}$ \\
\hline V & - Explicação sobre derivadas e integral; Velocidade e aceleração; \\
\hline
\end{tabular}

Quadro V: Conteúdos dos episódios da turma A - resumo

\section{Episódio I}

No início dessa aula (IA), o professor realizou uma correção de exercícios de um questionário online sobre unidades de medidas. Após essa correção, o tema da aula foi velocidade instantânea e aceleração instantânea para um movimento 
unidimensional. Nesse episódio foram excluídos os comentários iniciais da resolução de exercícios. Abaixo estão as anotações das aulas com as transcrições dos comentários do professor sobre o conteúdo explicitado.

O professor inicia a explicação falando sobre a equação horária do movimento:

" $x(t)$ é uma função, que é contínua no tempo e só faz sentido com um sistema de referência, ou seja, depende do referencial que eu escolho. Essa função é difícil interpretar. Onde o corpo para? Está indo para trás ou para frente?"

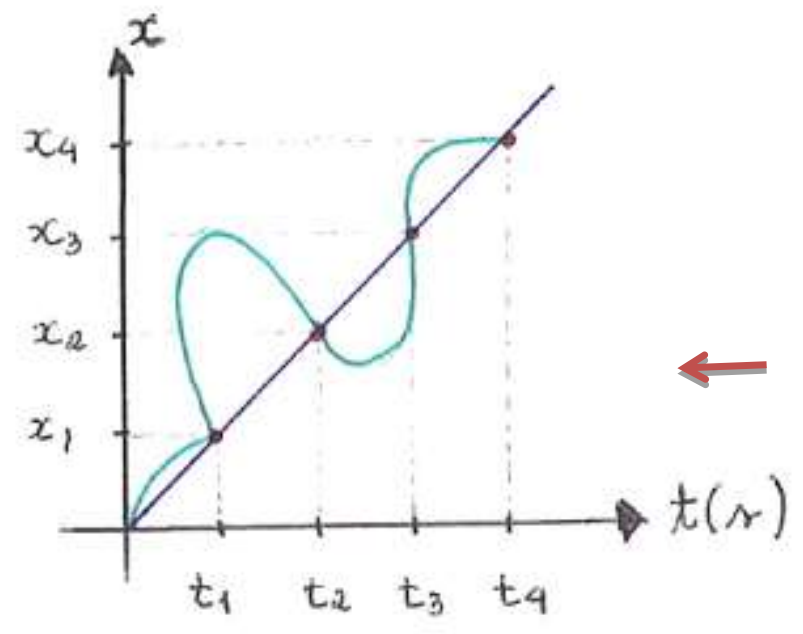

O professor desenha um esboço de gráfico na lousa e comenta:

"Nunca meço uma função, e sim valores discretos que formam gráficos (funções contínuas) e tabelas"

"Nesse exemplo entre os pontos não sabemos como é o movimento. Pode ser uma funcão de primeiro grau, uma reta".

Ao falar sobre o estudo do movimento, o professor cita as funções matemáticas para relacionar o tipo de movimento com o tipo de função. Nessa representação o professor utiliza uma notação comum na matemática para o estudo de funções $(f(x)=$ função $f$ para a variável $x)$, trocando a letra f por $x$ (posição) e a variável $x$ por $t$ (tempo). É comum no estudo do movimento a utilização de funções matemáticas para a descricão dos movimentos, tanto no Ensino Médio quanto no Ensino Superior. O professor continua sua explicação sobre o movimento:

"O movimento mais simples possível é o movimento uniforme, que percorre distâncias iguais em tempos iguais".

$$
\frac{\Delta x}{\Delta t}=\text { constante }=\text { velocidade }
$$


"A equação é a forma matemática de expressar o que expressamos em palavras"

Ao descrever na lousa as equações de velocidade o professor discorre:

"Podemos ter notacões diferentes para a mesma coisa, as equações são iguais, só mudou a letra".

$$
\begin{gathered}
v=\frac{\Delta x}{\Delta t}=\frac{x_{f}-x_{i}}{t_{f}-t_{i}} \rightarrow \frac{x\left(t_{f}\right)-x\left(t_{i}\right)}{t_{f}-t_{i}} \\
x(t) \rightarrow \text { reta } \\
v=\frac{x(t)-x\left(t_{0}\right)}{t-t_{0}}
\end{gathered}
$$

A ideia que é possível ter notações matemáticas diferentes para descrever um mesmo movimento é verbalizada explicitamente pelo professor em sua explicação. Ao comentar e escrever na lousa essas diferentes notações ele demonstra para o aluno que as representações matemáticas podem ser distintas para representar uma mesma ideia ou conceito.

O professor continua sua explicação:

"Estamos falando em MRU, movimento retilíneo, retilíneo

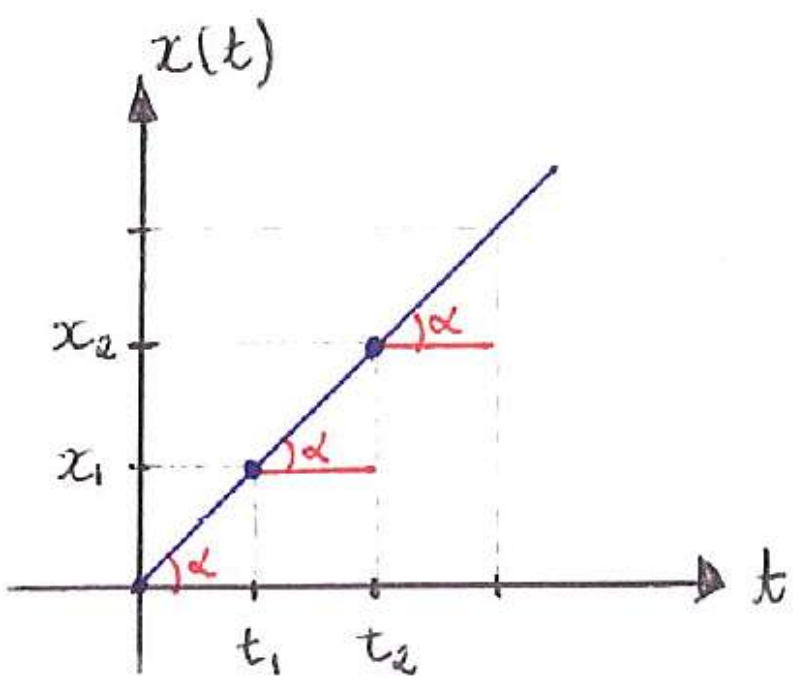
porque é unidimensional".

$$
\begin{aligned}
& x(t)-x\left(t_{0}\right)=v\left(t-t_{0}\right) \\
& x(t)-x\left(t_{0}\right)=v\left(t-t_{0}\right)
\end{aligned}
$$

"Praticamente em 100\% dos casos dos movimentos unidimensionais com referência de escolha, escolhemos $t_{0}=0$ ".

$$
x(t)=x_{0}+v \cdot t
$$


“Usamos to diferente, por exemplo, em problemas de encontro onde um carro sai antes que outro carro. Olhando a equação, sem fazer dá para saber que esse gráfico é uma reta".

A equação é uma função de primeiro grau, e por isso, o professor já intui que seu gráfico é uma reta. Para um aluno, fazer essa "ligação" só é possível se ele conhecer as funções matemáticas e suas representações gráficas.

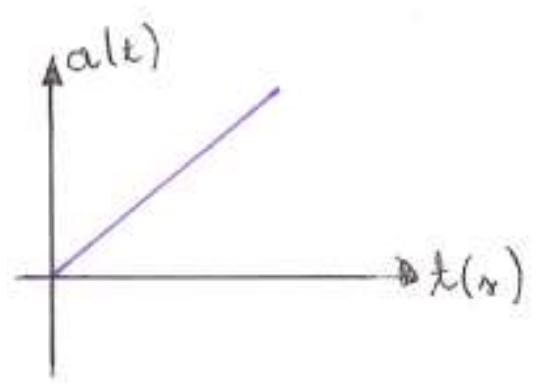

O professor constrói esboços de outros gráficos na lousa e tece comentários:

“Qual é a interpretação geométrica do gráfico?”

$$
\operatorname{tg} \alpha=\frac{\Delta x}{\Delta t}=v
$$

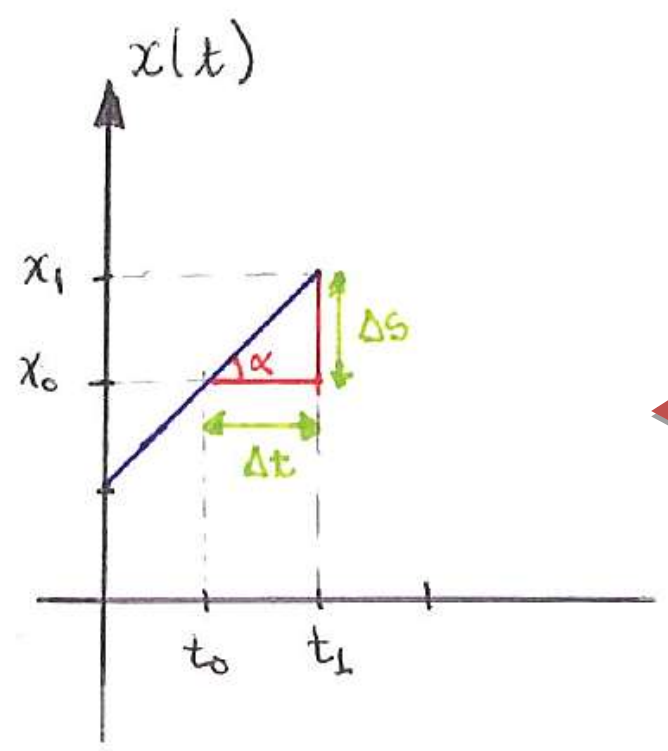

“ $v$ é também a inclinação da reta. A tangente do ângulo é numericamente igual porque delta $x$ por delta $t$ tem dimensão e tangente do ângulo é adimensional".

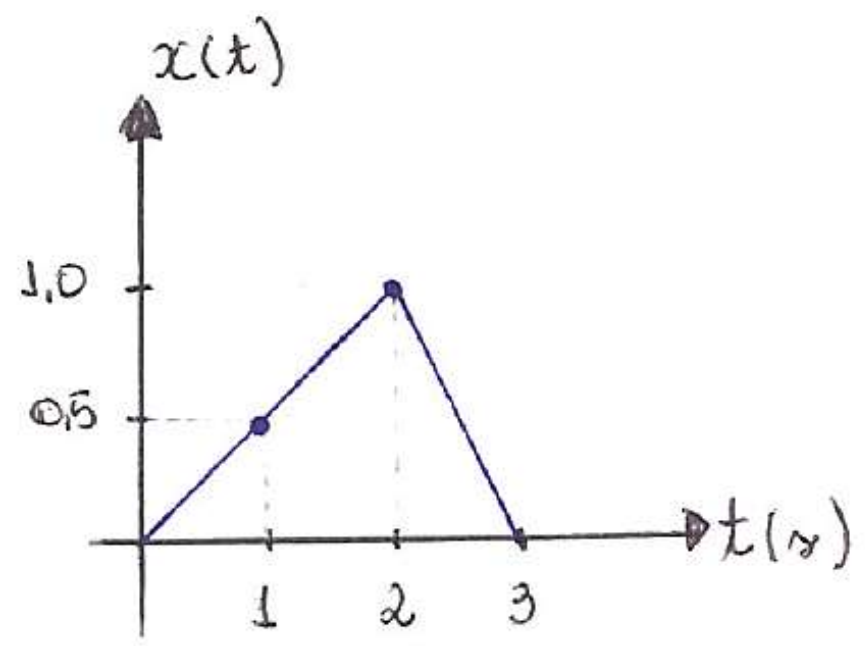

"Para o movimento uniforme, é o mesmo ângulo, eu escolho o melhor trecho".

O professor ressalta que apesar da tangente do ângulo relacionado à inclinação da reta não ter unidade (propriedade 
matemática), essa mesma tangente "adquire" um significado físico quando através dela encontra-se a velocidade de um movimento. As propriedades gráficas (inclinação, taxa de variação etc.) são novamente utilizadas na apresentação do conteúdo.

Na sequência, o professor continua:

"Qualquer movimento que não seja uniforme é chamado de movimento acelerado. Freado também é chamado de acelerado na física. Velocidade não é mais constante."

O professor faz um esboço de gráfico na lousa para começar a explicar a velocidade média e escreve equações:

$$
\begin{gathered}
v=\frac{\Delta x}{\Delta t}=? \rightarrow \text { velocidade média em } \Delta t \\
\bar{v}_{t_{1} \rightarrow t_{2}}=\frac{x\left(t_{2}\right)-x\left(t_{1}\right)}{t_{2}-t_{1}}
\end{gathered}
$$

"A velocidade média é dada por essa equação. Acredita na teoria e vai atrás do que a matemática fornece”.

$$
\bar{v}_{0 \rightarrow 3}=\frac{x(3)-x(0)}{3-0}=\frac{0-0}{3}=0 \mathrm{~m} / \mathrm{s}
$$

"O cálculo da velocidade de $t$ zero a $t$ três dá zero. É antiintuitivo. O que é intuitivo na mecânica aristotélica, a de Newton não é intuitiva. A velocidade média é zero porque nós definimos a velocidade média desse jeito. Tenho que acreditar no conceito diz e calcular, por mais absurda é a resposta certa".

No trecho acima, o professor explica o conceito de velocidade média e sua definição, explicitando que muitas vezes esse conceito pode soar anti-intuitivo e por 
isso é necessário "acreditar" nos resultados matemáticos. O resultado numérico expressa um significado que muitas vezes o estudante não consegue extrair, e por isso, o professor usa a palavra "acreditar", que podemos pensar como operar mecanicamente as fórmulas sem conjecturar sobre seus significados e resultados, simplesmente usar a matemática como ferramenta.

O professor conclui:

"Para ter uma informação mais precisa do que ocorreu posso calcular a velocidade média para intervalos de tempo menores".

$$
\begin{gathered}
\bar{v}_{0 \rightarrow 1}=\frac{0,5}{1}=0,5 \mathrm{~m} / \mathrm{s} \\
\bar{v}_{1 \rightarrow 2}=\frac{1-0,5}{1}=0,5 \mathrm{~m} / \mathrm{s} \\
\bar{v}_{2 \rightarrow 1}=\frac{0-1}{1}=-1 \mathrm{~m} / \mathrm{s}
\end{gathered}
$$

Após essa explicação, o professor faz outro gráfico na lousa e explica:

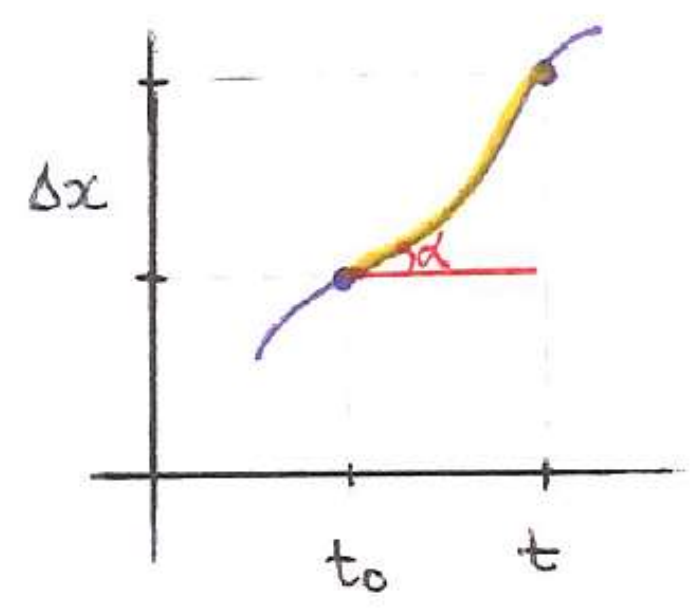

$$
\begin{gathered}
\operatorname{tg} \alpha=\bar{v} \\
\bar{v}=\frac{\Delta x}{\Delta t}
\end{gathered}
$$

"Se aproximar $t$ de $t_{0}$ conseguimos encontrar a velocidade instantânea. Esse procedimento que descrevi com palavras precisamos expressar matematicamente. $O$ conceito de velocidade instantânea é uma abstração matemática”. 
O professor então discorre sobre o que é um limite e qual a relação com os conceitos físicos estudados. Nesse momento da aula o professor explica as operações matemáticas (do cálculo) anteriormente à "aplicação" na física:

"O que é limite?".

$$
\begin{gathered}
v(t)=\lim _{\Delta t \rightarrow 0} \frac{\Delta x}{\Delta t} \\
f(x)=3 x^{2}+5 \\
\lim f(x), x \rightarrow 2 \equiv f(2) \\
3 x^{2}+5=3(2)^{2}+5=17 \\
\lim _{x \rightarrow 2}\left(3 x^{2}+5\right)=17
\end{gathered}
$$

"Essa função é definida. Para quando tem uma função que não é definida em um ponto o limite faz sentido".

$$
\begin{gathered}
f(x)=\frac{x^{2}-9}{x-3} \text { para } x \neq 3 \\
\lim _{x \rightarrow 3} f(x) \rightarrow \text { "ponto que completa a reta" } \\
f(x)=\left\{\begin{array}{cc}
\frac{x^{2}-9}{x-3} & x \neq 3 \\
\text { se } x=3 &
\end{array}\right.
\end{gathered}
$$

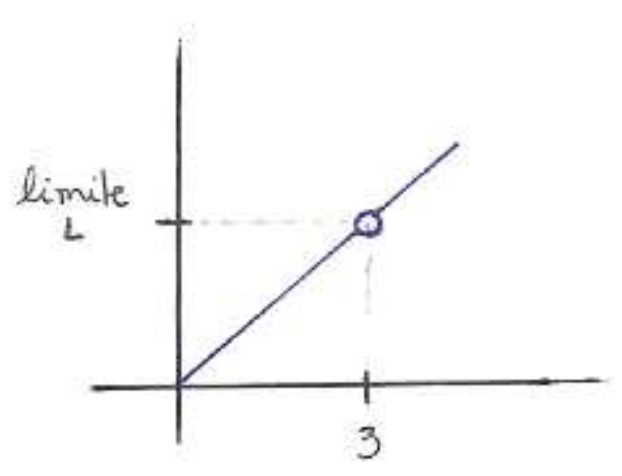

"Existe um limite"

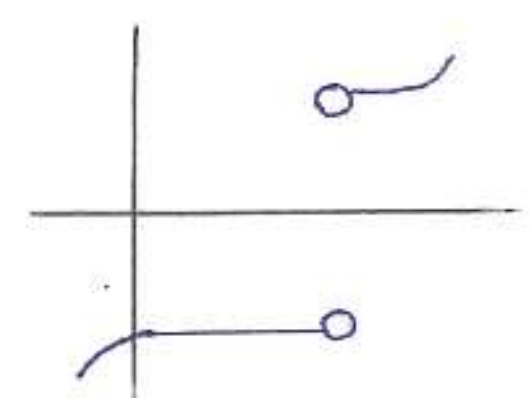

"Nao consigo definir um único valor, não existe um limite".

$$
\begin{gathered}
v(t)=\lim _{\Delta t \rightarrow 0} \frac{\Delta x}{\Delta t} \\
v(t)=\frac{d x}{d t}
\end{gathered}
$$

"Essa equação é uma forma condensada, uma convenção de representação" 
Novamente, o professor apresenta outros formalismos matemáticos que permitem calcular a velocidade, ou seja, outras representações que a física utiliza para o estudo de um mesmo conceito. Ele continua explicando limites e derivadas:

"Derivada nada mais é que um limite. Calcular uma derivada é calcular um limite".

$$
\begin{gathered}
f(x)=\frac{x^{2}-9}{x-3} \text { para } x \neq 3 \rightarrow \frac{(x+3) \cdot(x-3)}{(x-3)}=x+3 \\
f^{\prime}(x)=x+3 \\
f^{\prime}(3)=6 \\
\lim _{x \rightarrow 3} \frac{x^{2}-9}{x-3}=6 \\
x(t) \rightarrow \text { função } \lim _{\Delta t \rightarrow 0} \frac{\Delta x(t)}{\Delta t} \\
\lim _{\Delta t \rightarrow 0} \frac{\Delta x}{\Delta t} \\
\lim _{\Delta t \rightarrow 0} \frac{x(t)-x\left(t_{0}\right)}{t-t_{0}} \rightarrow \text { número } \\
\frac{d x}{d t} \rightarrow \text { derivada } \\
\left.\frac{d x}{d t}\right|_{t=t_{0}} \rightarrow \text { derivada }
\end{gathered}
$$
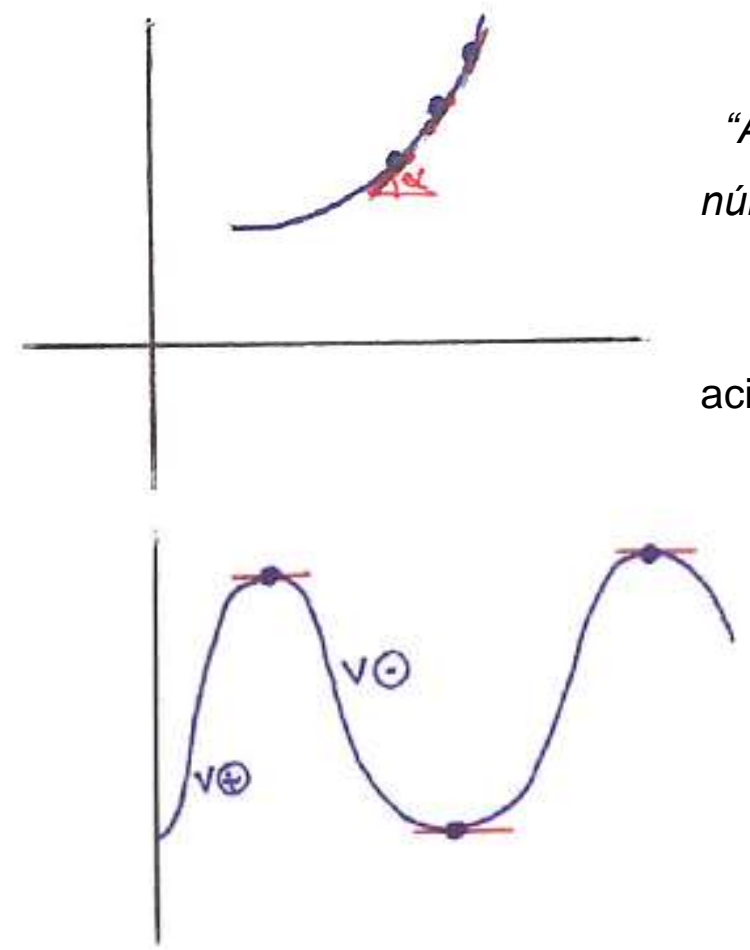

"A resposta é uma função: derivada" . "Resposta é um número"

O professor enfatizou a diferença dos dois exemplos acima citados.

"Qual o significado geométrico dessa derivada? A derivada é uma função que dá o valor da inclinação de tangência à curva para cada ponto da curva. Se a 
derivada é positiva, é crescente. Se é negativa, é decrescente".

Na explicação, o professor explicou detalhadamente: "Velocidade é numericamente igual à inclinação da reta tangente àquele ponto".

O professor então exemplificou com o que ele denominou um exemplo concreto de MRUV:

$$
\begin{gathered}
x(t)=a t^{2}+b t+c \rightarrow \text { parábola } \\
x(t)=\lim _{\Delta t \rightarrow 0} \frac{x(t+\Delta t)-x(t)}{\Delta t} \\
x(t+\Delta t)=a(t+\Delta t)^{2}+b(t+\Delta t)+c \\
=a\left(t^{2}+2 \cdot t \cdot \Delta t+\Delta t^{2}\right)+b \cdot t+b \cdot \Delta t+c \\
=a t^{2}+2 \cdot a \cdot t \Delta t+a \Delta t^{2}+b \cdot t+b \cdot \Delta t+c \\
x(t)=a t^{2}+b t+c \\
\Delta x=x(t+\Delta t)-x(t) \\
\Delta x=a \cdot t^{2}+2 a \cdot t \cdot \Delta t+a \Delta t^{2}+b t+b \Delta t+c-a t^{2}-b t-c \\
\Delta x=2 a \cdot t \cdot \Delta t+a \cdot \Delta t^{2}+b \cdot \Delta t \\
\frac{\Delta x}{\Delta t}=\frac{2 a \cdot t \cdot \Delta t}{\Delta t}+\frac{a \cdot \Delta t^{2}}{\Delta t}+\frac{b \cdot \Delta t}{\Delta t} \\
\frac{\Delta x}{\Delta t}=2 a t+a \Delta t+b \\
\lim _{\Delta t \rightarrow 0} \frac{\Delta x}{\Delta t}=2 a t+a \Delta t+b=2 a t+b
\end{gathered}
$$

Esse exemplo "concreto" na verdade foi a dedução de uma equação literal que representa o movimento, mas sem um exemplo físico específico.

" $x(t)$ é um polinômio de grau qualquer. Sabendo a derivada de seno, cosseno, $e^{t}$, Ine, mata praticamente todas as derivadas da física".

É ressaltado aqui o aluno precisa saber derivar para aplicar na física, ou seja, é necessário saber operações "técnicas". O professor demostrou então rapidamente exemplos de derivações de polinômios. Após esses exemplos, mencionou: 
"Os físicos primeiro que os matemáticos substituíram o limite por $d x / d t$. Para facilitar a notação. $O$ que significa geometricamente a derivada? É uma função que me diz para cada ponto da curva qual a inclinação da reta tangente naquele ponto."

Nesse trecho o professor ressalta que muitas vezes alguns símbolos e algoritmos matemáticos foram utilizados e desenvolvidos primeiro por físicos, que buscam "aperfeiçoar" notações e representações nas aplicabilidades físicas.

Nesse episódio, foi possível perceber que o professor se preocupou em demonstrar diferentes notações matemáticas e equações utilizadas na física para o estudo do movimento, como por exemplo, no cálculo da velocidade. É importante pensar que o aluno que cursa a disciplina Fundamentos de Mecânica pela primeira vez é um aluno que finalizou seus estudos no Ensino Médio recentemente e que só teve contato com representações utilizadas comumente nesse nível de ensino. A inserção de novas representações matemáticas explicita que no nível superior o aporte matemático é mais amplo e complexo e que discutir essas diferentes formas de representações é importante para a reflexão das relações que a matemática tem com a física.

Nessa aula também é notório que o professor introduziu ideias e formalismos do cálculo diferencial integral e utilizou a própria aula para explicar e exemplificar esses formalismos para os alunos, primeiramente com um enfoque puramente matemático e posteriormente com ideias do estudo do movimento.

\section{Episódio II}

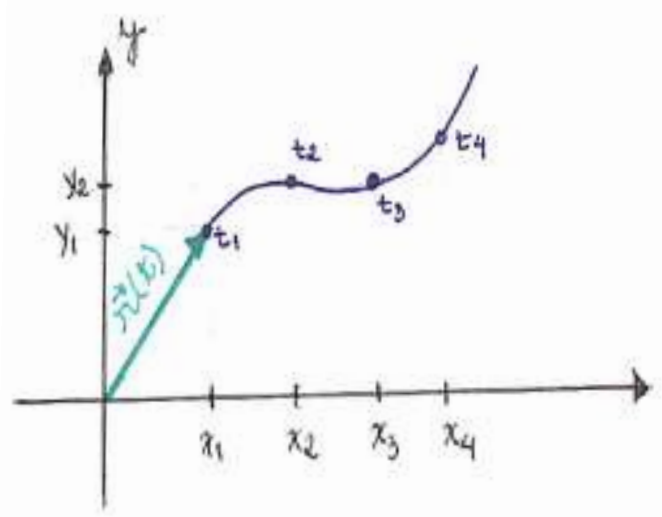

Na aula IIIA, o professor iniciou o estudo do movimento bidimensional. Para isso, ele revisou detalhadamente o conceito de vetores e suas operações. O professor fez o esboço de um gráfico posição por tempo e comentou: 
"O que é equação horária, como eu posso interpretar o movimento nesse ponto?" A gente sempre quer, é conveniente, escrever as leis da física, as relações importantes numa forma independente do sistema de coordenadas. A conta que eu tô fazendo em particular não, mas a lei da Física independe do sistema de coordenadas".

O professor definiu vetor posição e falou sobre a diferença entre grandezas vetoriais e grandezas escalares.

"O que é um vetor? Vetor é uma grandeza física que não é completamente caracterizado por um número. Quando eu digo que é uma grandeza física eu estou dizendo que é uma ideia, é um conceito, que não depende da representação que eu estou dando a ele".

O professor fez um paralelo para explicar:

"A ideia da quantidade 3, é uma ideia presente, se eu digo que eu tenho 3 lápis, todo mundo consegue imaginar isso. Eu posso ter três lápis, eu posso ter três pedras, três carteiras etc. ; existe uma abstração por trás de carteiras, pedras, lápis ... que diz respeito a essa ideia de quantidade. E essa ideia, esse conceito de quantidade independe da representação que eu dê a ele. Eu posso representar, por exemplo, a quantidade três com um algarismo arábico e também com um algarismo romano. Quando eu estou representando o três assim (arábico) eu estou representando de uma forma diferente a mesma ideia abstrata de quantidade. Existem na natureza grandezas que são mais complicadas e que não podem ser completamente descritas apenas com uma quantidade, além de uma quantidade eu preciso de uma direção e um sentido".

Outra ideia presente no episódio que explicita a relação ferramental da matemática com a física é a ideia de quantificar (mesmo com representações 
diferentes). Na física, precisamos quantificar resultados, ocorrências e a matemática permite essa quantificação. Novamente, o professor menciona que existem formas diferentes de representação e utiliza uma analogia simples para explicar isso aos seus alunos.

Continuando a explicação, ele apresentou o vetor: "O vetor é uma entidade matemática associada a um módulo, uma direção e um sentido. Vetores são independentes do sistema de coordenadas".

O vetor é matemático, e através dele podemos extrair ideias da física. Nesse episódio também fica explícita uma diferenciação da física com a matemática na introdução dos conceitos iniciais da mecânica, com um enfoque grande no "suporte" matemático necessário para estudar física: os vetores e suas operações.

O professor explicou detalhadamente as regras de operações com vetores, com desenhos na lousa:
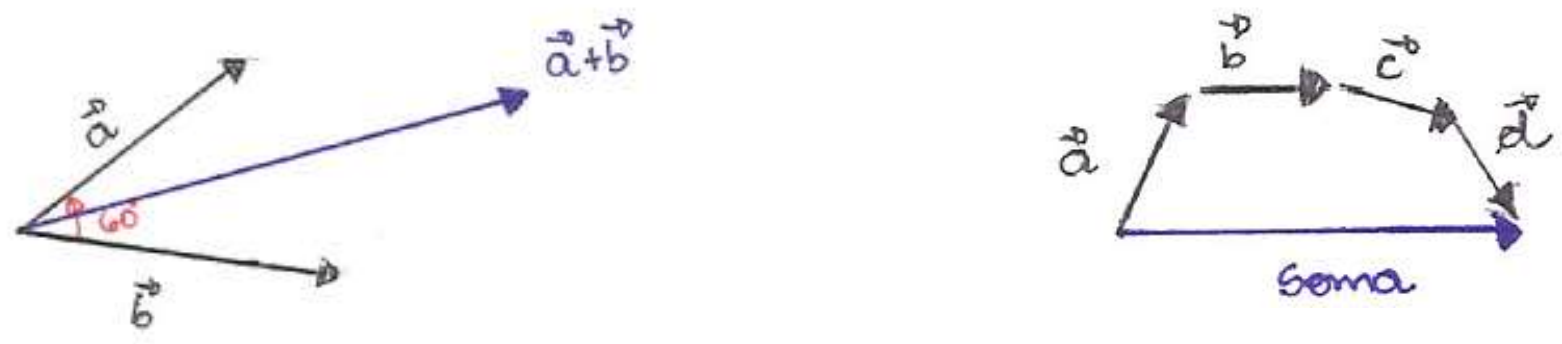

O professor questionou se os alunos tinham visto em Geometria Analítica operação com vetores, e naquele momento do curso os alunos viram parcialmente. O professor então demostrou e explicou a projeção de um vetor e seus componentes: 


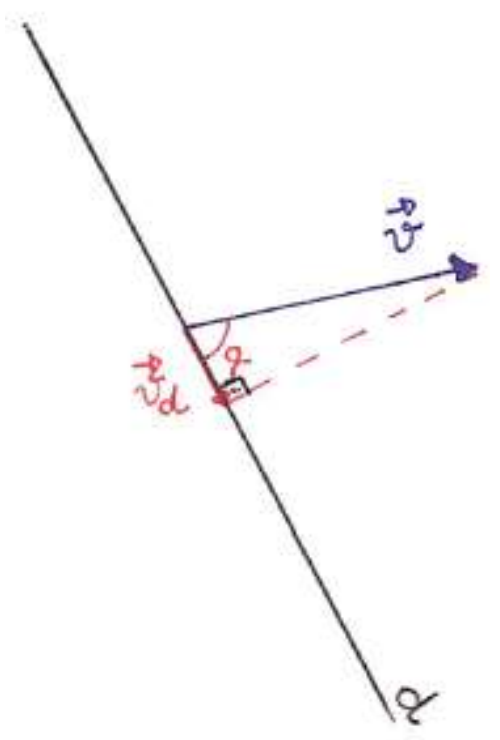

$|\vec{v}| \cdot \cos \alpha=\left|\vec{v}_{d}\right|$

$$
\vec{v}_{1} \cdot \vec{v}_{2}=v_{1} \cdot v_{2} \cdot \cos \theta
$$

O professor continuou discorrendo sobre vetores e citou os tensores:

"Existem na natureza coisas mais complicadas ainda que os vetores. Por exemplo, a tensão que a gente tem em uma superfície, se eu tenho uma membrana elástica, por exemplo, uma cama elástica, se alguém fica em pé em certo ponto da cama elástica, eu quero descrever a reação da membrana a essa compressão, a grandeza que dá essa reação é uma grandeza ainda mais complicada que eu vetor, ela tem nove componentes. Essa grandeza é um tensor" (...)

"A grande vantagem de fazer uma descrição do movimento em termos de vetores, ou escrever uma equação, por exemplo, a equação da gravitação de Einstein em termos de tensores, é que a gente está formulando a teoria de um jeito que independe do sistema de coordenada".

O professor fez descrições detalhadas de representação de vetores e versores, passo por passo, enfatizando que o detalhamento é importante para conseguir "operacionalizar" as ideias da física. Então, o professor explicou produto escalar e produto vetorial, conteúdos que fazem parte do curso de geometria analítica. Após, o professor cita:

"Nós vamos conseguir derivar vetor, integrar vetor, vamos conseguir achar trajetória, ou seja, fazer toda uma representação do movimento bidimensional completa, geral, muito mais prática de ser feita e adequada a problemas que não são retinhos, movimento retilíneo uniforme etc.. Não é 
adequado no colegial ficar ensinando tudo isso, todo esse formalismo mais geral dos vetores faz parte do curso de física, engenharia, computação, área de ciências exatas (...). Não é que está errado, o jeito que vocês aprenderam a manipular vetores no colegial não é um jeito eficiente para fazer conta, realmente. Serve para achar força resultante, por exemplo, mas não para um movimento mais sofisticado".

O docente ressalta explicitamente que os alunos estão entrando em contato com um formalismo diferente daquele utilizado anteriormente no Ensino Médio e justifica a introdução dessas novas representações em função do estudo de movimentos mais amplos e complexos que os estudados no nível médio. Para isso, em suas aulas, ele revisa as representações que os alunos já deveriam conhecer e apresenta esse novo formalismo efetuando comparações e reflexões sobre suas utilizações.

\section{Episódio III}

$\mathrm{Na}$ aula IVA, o professor apresentou os conceitos de aceleração; MRUV: movimento retilíneo uniformemente variado, fez aplicações do MRUV; descreveu a equação da trajetória e resolveu exercícios.

O professor começou a aula definindo a aceleração utilizando limite e derivada:

$$
\vec{a}(t)=\lim _{\Delta t \rightarrow 0} \frac{\Delta \vec{v}}{\Delta t}=\lim _{\Delta t \rightarrow 0} \frac{\vec{v}(t+\Delta t)-\vec{v}(t)}{\Delta t}=\frac{d \vec{v}}{d t}
$$

$\vec{a}=a x \vec{\imath}+a y \vec{\jmath} \quad$ "Matematicamente fica mais fácil

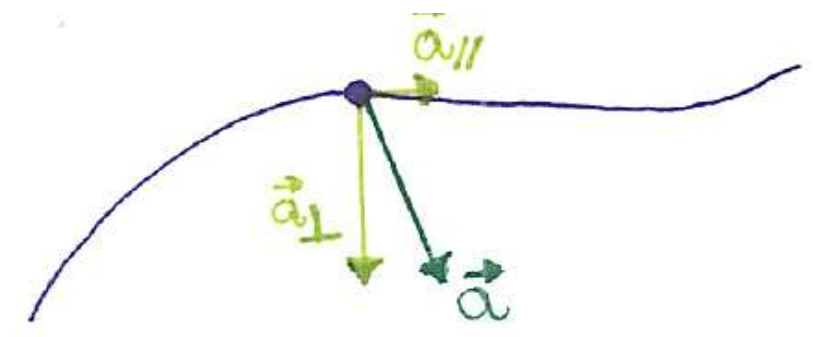

representar a aceleração com essa notação, a interpretação física fica mais fácil".

$\vec{a}=a_{\|}+a_{\perp}$

O professor comenta sobre a física como ciência e explana sobre o MRUV: 
"O objetivo máximo da física é entender a realidade".

"O MRUV é o movimento mais simples que existe para exemplificar".

$$
\begin{gathered}
x=x_{0}+v_{0} t+1 / 2 a t^{2} \\
v=v_{0 x}+a t \\
a=c t e \\
\vec{r}(t)=\vec{r}_{0}+\vec{v}_{0} t+1 / 2 \vec{a} t^{2} \\
\vec{v}(t)=\vec{v}_{0}+\vec{a} t \\
\vec{a}=c t e \\
\vec{a}=c t e
\end{gathered}
$$

$$
\begin{gathered}
\vec{v}(t)=\vec{v}\left(t_{0}\right) \\
\vec{v}=v_{0 x} \vec{\imath}+v_{y_{0}} \vec{\jmath} \\
\vec{r}(t)=\vec{r}\left(t_{0}\right) \\
x_{0} \vec{\imath}+y_{0} \vec{\jmath}+z_{0} \vec{k}
\end{gathered}
$$

"Se só o módulo da velocidade estiver mudando e a direção não o movimento é retilíneo".

Nas suas representações matemáticas o professor utiliza primeiramente as funções horárias semelhantes às utilizadas no nível médio para depois escrever com a representação e formalismo vetorial que foi introduzido nas aulas anteriores, criando um "paralelo" para o aluno transitar entre as diferentes representações. O professor continua sua explicação sobre a aceleração:

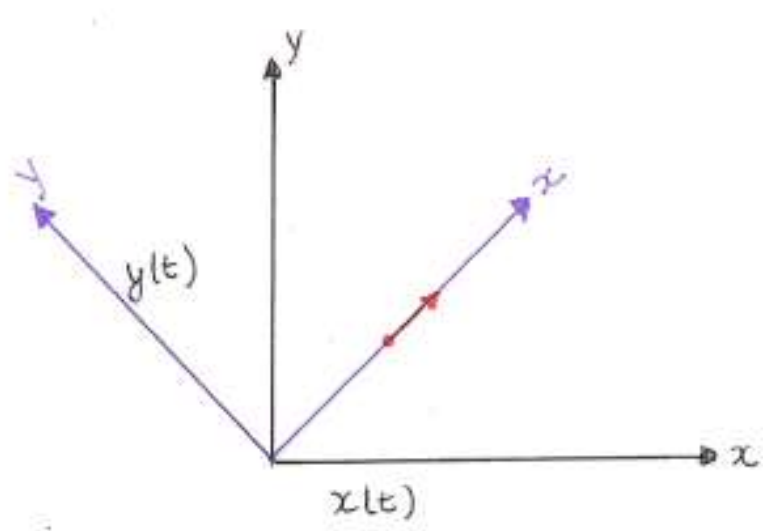

"O que ocorre quando a aceleração e a velocidade inicial não são paralelas? Curvo. Se a aceleração e a velocidade inicial são constantes definem um plano".

"O que significa dizer que um movimento é plano? É um movimento bidimensional. É possível escolher uma referência para isso. Sem perda de generalidade, 
podemos fazer a descrição de um movimento MRUV em 2 dimensões $(x, y)$. A escolha de uma coordenada é minha".

Equação da Trajetória:

$$
\vec{r}(t)=x(t) \vec{\imath}+y(t) \vec{\jmath}
$$

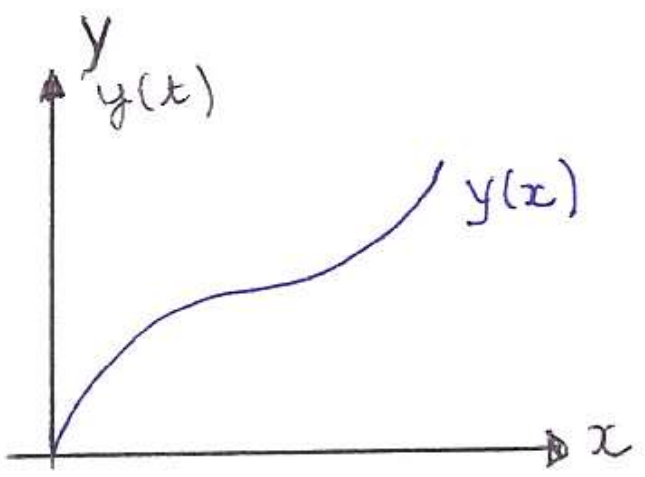

"Eliminado o tempo encontramos a equação da trajetória".

"Se for uma curva não é uma função pois teremos dois y para $1 x$ ".

O professor exemplifica suas explicações com representações gráficas que ilustram suas colocações. O professor então continua sua explicação falando sobre lançamentos oblíquos e deduzindo suas equações:

$$
\begin{gathered}
y=y_{0}+v_{0 y} t+\frac{a t^{2}}{2} \\
x=x_{0 y} t+v_{0 x} t \rightarrow \frac{x-x_{0}}{v_{0 x}}=t \\
y=y_{0}+v_{0 y} \frac{x-x_{0}}{v_{0 x}}+\frac{1}{2} a \frac{x-x_{0}{ }^{2}}{v_{0 x}} \\
y-y_{0}=\frac{v_{0 y} x}{v_{0 x}}-\frac{v_{0 y} x_{0}}{v_{0 x}}+\frac{1 a x^{2}}{2 v_{0 x}^{2}}-\frac{1 a x x_{0}}{2 v_{0 x}^{2}}+\frac{1 a x_{0}^{2}}{2 v_{0 x}^{2}} \\
y=a x^{2}+b x+c
\end{gathered}
$$

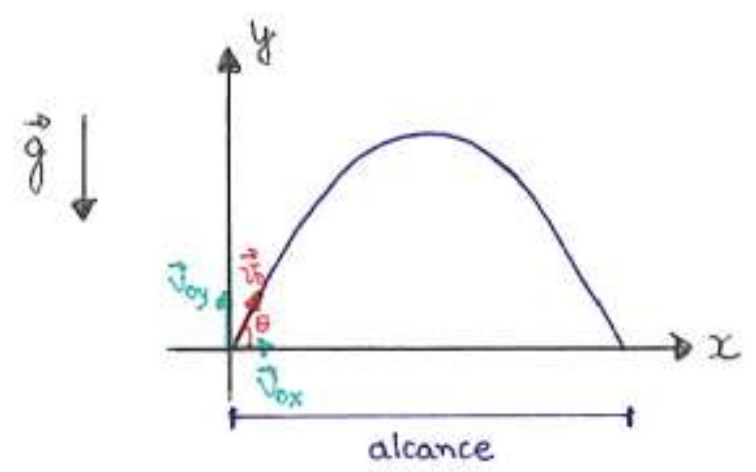

"Para descrever realmente o movimento de uma bola deveríamos tratá-la como corpo rígido (com movimentos internos do sistema), mas estamos tratando como ponto material". 
"É conveniente colocar a origem do movimento na origem da referência".

$$
\begin{gathered}
\overrightarrow{v_{0}}=v_{0} \cos \theta \vec{\imath}+v_{0} \operatorname{sen} \theta \vec{\jmath} \\
a=-g \vec{\jmath} \\
v_{x}=c t e=v_{0} \cos \theta \\
v_{y}=v_{0} \operatorname{sen} \theta-g t \\
y=y_{0}+v_{0} \operatorname{sen} \theta t-1 / 2 g t^{2} \\
x=x_{0}+v_{0} \cos \theta t \\
t=\frac{x}{v_{0} \cos \theta} \\
y=y_{0}+v_{0} \operatorname{sen} \theta \frac{x}{v_{0} \cos \theta}-1 / 2 g\left(\frac{x}{v_{0} \cos \theta}\right)^{2} \\
y=\operatorname{tg} \theta x-\frac{g}{2 v_{0}^{2} \cos ^{2} \theta}
\end{gathered}
$$

“Qual é a altura máxima? Devemos achar $t_{m}$ para $v_{y}=0$ ".

$$
\begin{gathered}
v_{y}\left(t_{m}\right)=0 \\
v_{y}=v_{0} \operatorname{sen} \theta-g
\end{gathered}
$$

"O que caracteriza fisicamente a altura máxima? Ponto em que a componente y da velocidade muda de sentido. Ela é instantaneamente nula".

$$
\begin{gathered}
0=v_{0} \operatorname{sen} \theta-g t \\
t_{m}=\frac{v_{0} \operatorname{sen} \theta}{g} \\
y\left(t_{m}\right) \rightarrow H \text { máximo } \\
y\left(t_{m}\right)=H=v_{0} \operatorname{sen} \theta t_{m}-\frac{1}{2} g t_{m}^{2} \\
=\frac{v_{0} \operatorname{sen} \theta v_{0} \operatorname{sen} \theta}{g}-\frac{1}{2} g \frac{v_{0}^{2} \operatorname{sen}^{2} \theta}{g^{2}} \\
H=\frac{v_{0}^{2} \operatorname{sen}^{2} \theta}{g}-\frac{1}{2} \frac{v_{0}^{2} \operatorname{sen}^{2} \theta}{g} \\
H_{\text {max }}=\frac{1}{2} \frac{v_{0}^{2} \operatorname{sen}^{2} \theta}{g}
\end{gathered}
$$


"Para essa escolha do sistema de coordenadas e para esse problema". "Para descobrir o alcance é só substituir $2 t_{m}$ na equação de $x "$.

$$
\begin{gathered}
x\left(2 t_{m}\right)=A=v_{0} \cos \theta \cdot 2 \frac{v_{0} \operatorname{sen} \theta}{g} \\
A=\frac{v_{0}^{2}}{g} 2 \operatorname{sen} \theta \cos \theta \\
\qquad A=\frac{v_{0}^{2}}{g} \operatorname{sen} 2 \theta
\end{gathered}
$$

"O alcance é máximo quando $\operatorname{sen} 2 \theta=1$, ou seja, quando $\theta=45^{\circ}$ ".

“Matematicamente essa equação mostra que para o mesmo alcance podemos ter ângulos diferentes. A Se fixar o alcance, o que muda é a velocidade inicial”.

"Com que velocidade o corpo chega ao solo?"

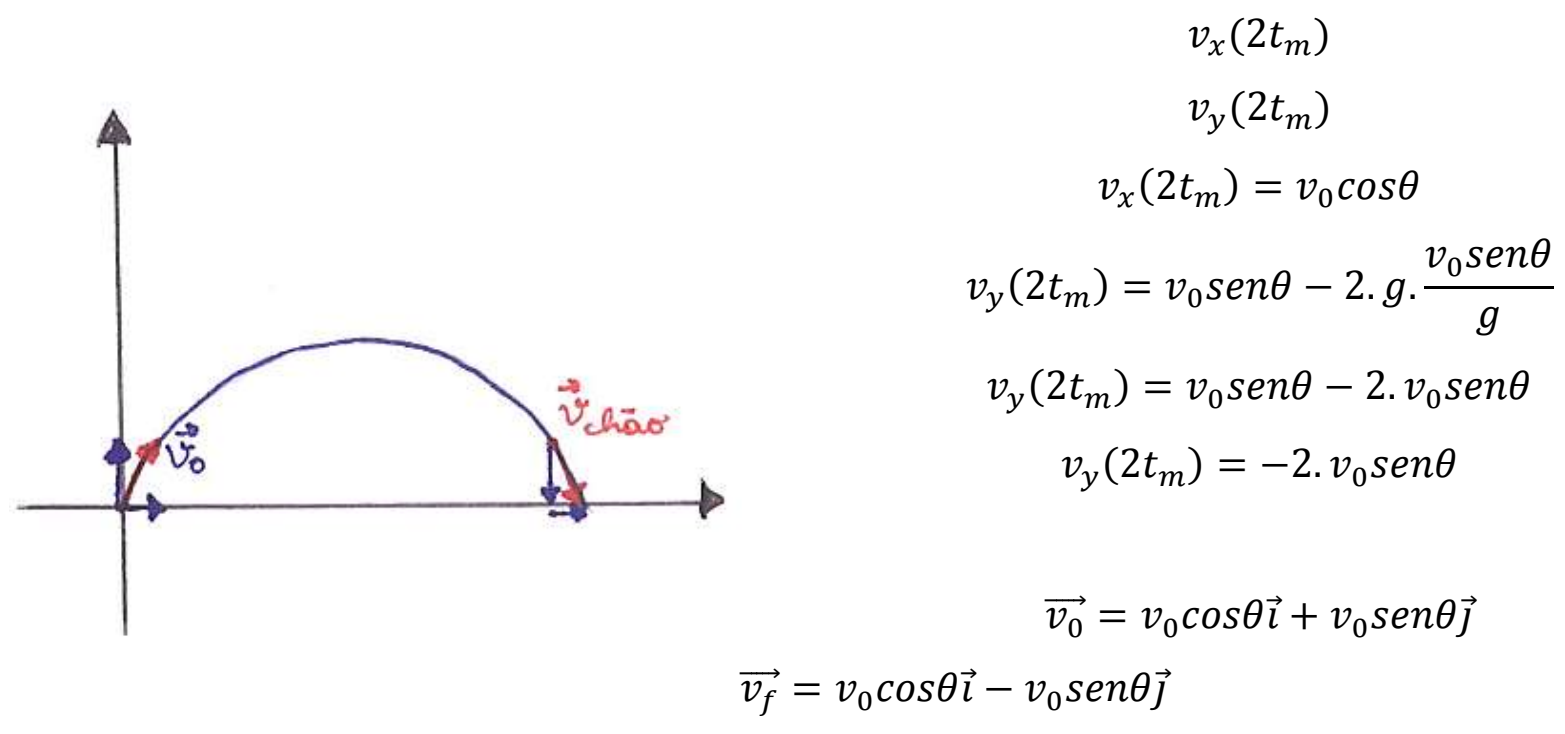

$\mathrm{Na}$ explicação acima descrita, o professor deduziu literalmente equações matemáticas para o estudo do lançamento oblíquo. Após essa demonstração, ele realizou na lousa um exercício trocando as grandezas físicas por valores numéricos (utilizando as mesmas equações descritas anteriormente). 
Nesse episódio, é possível perceber que ao iniciar o estudo do MRUV o professor atentou-se em explicitar novamente representações diferentes para as equações para depois desenvolver literalmente essas equações no contexto do estudo de um lançamento oblíquo. Após essas deduções, o professor se utilizou das equações para resolver um exercício com valores numéricos em que era necessário somente substituir as grandezas pelos seus respectivos valores numéricos, ou seja, para resolver um problema "tipo" de lançamento oblíquo.

\section{Episódio IV}

$\mathrm{Na}$ aula VA o professor continuou a aula anterior, resolveu na lousa exercícios de lançamentos e introduziu o movimento circular uniforme.

Um dos exercícios que o professor resolveu na lousa explicando é um exercício de lançamento horizontal de uma bomba que estava em um avião e tem como alvo um carro que está em movimento.

O professor leu o enunciado, que resumidamente cita que o avião está à 300 $\mathrm{m}$ de altura em relação ao solo, com uma velocidade horizontal de $180 \mathrm{~km} / \mathrm{h}$ e o

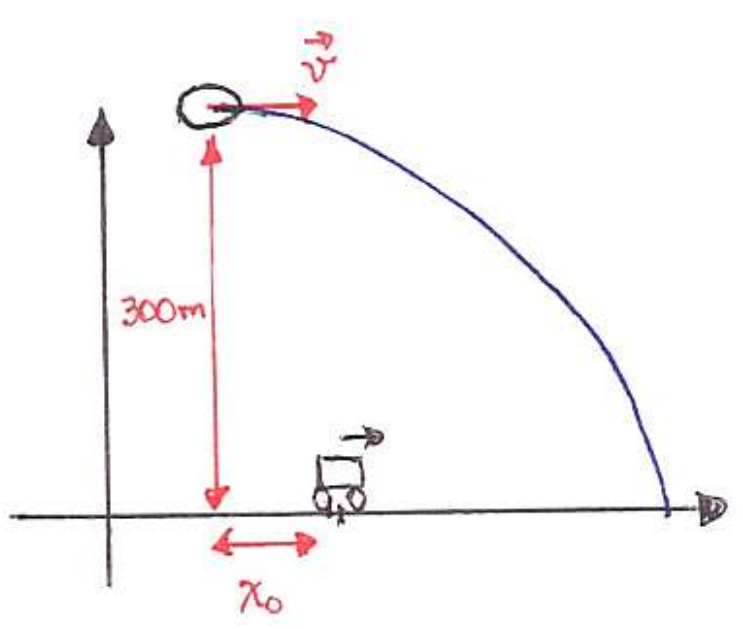
carro alvo está com uma velocidade constante de $90 \mathrm{~km} / \mathrm{h}$. A bomba será lançada com um ângulo de $30^{\circ}$ em relação à horizontal. Abaixo tem-se a resolução do exercício que foi realizada na lousa:

Bomba (MRUV em y e MRU em x)

$$
\begin{gathered}
\overrightarrow{v_{0 b}}=50 \cos 30 \vec{\imath}-50 \operatorname{sen} 30 \vec{\jmath} \\
y_{0 b}=300 \mathrm{~m} \\
x_{0 b}=0
\end{gathered}
$$

Carro (MRU em x)

$$
\begin{gathered}
\vec{r}(t)=\left(x_{0}+v_{o x} t\right) \vec{\imath}+\left(y_{0}+v_{o y} t+1 / 2 a t^{2}\right) \vec{\jmath} \\
\vec{r}_{b}(t)=25 \sqrt{3} t \vec{\imath}+\left(300-25 t-5 t^{2}\right) \vec{\jmath} \\
\vec{r}_{\text {carro }}=\left(x_{0}+25 t\right) \vec{\imath}
\end{gathered}
$$


$x($ carro $)=x($ bomba $)$ no instante $t^{*}$ em que a bomba toca o solo.

$$
\begin{gathered}
y_{b}(t)=300-25 t-5 t^{2} \\
-5 t^{* 2}-25 t^{* 2}+300=0 \\
+t^{* 2}+5 t^{* 2}-60=0 \\
t_{1,2}^{*}=\frac{-b \pm \sqrt{\Delta}}{2 a} \\
t_{1,2}^{*}=\frac{-5 \pm 16}{2} \\
t^{*}=\frac{-5-16}{2}
\end{gathered}
$$

Durante a resolução, o professor teceu comentários sobre os valores numéricos encontrados:

"Esse número negativo não faz sentido físico no contexto do problema. O que significa um tempo negativo? Um evento que aconteceu antes do instante que eu escolhi para ser o tempo inicial igual a zero. No caso desse lançamento, se eu for por o meu relógio para trás eu posso completar essa trajetória matemática assim (completou a parábola no desenho) (...) Toda essa curva é representada por isso aqui (equação do segundo grau). Só que esse ponto aqui (ponto da parábola simétrico para altura igual a zero) não tem sentido físico no contexto do problema, porque a bomba não está fazendo essa parábola inteira. Não faz sentido aquela resposta negativa e a gente tem que perceber isso, analisar e ver se faz ou não sentido a resposta dependendo do enunciado".

$$
\begin{gathered}
t^{*}=\frac{-5+16}{2}=5,5 \mathrm{~s} \\
x_{c}\left(t^{*}\right)=x_{b}\left(t^{*}\right) \\
x_{0}+25 \cdot \frac{11}{2}=25 \cdot \sqrt{3} \cdot \frac{11}{2}-5\left(\frac{11}{2}\right)^{2} \\
x_{0} \cong 103 \mathrm{~m}
\end{gathered}
$$


"O que eu quero chamar a atenção é que tem que parar pra pensar o que cada problema está dizendo. A formulação é sempre a mesma, são essas situações básicas. Eu posso dar a velocidade, eu posso dar a posição ...E eu vou ter que combinar essas equacões com as funções físicas que estão sendo indicadas no enunciado pra compreender o que está sendo perguntado e o que eu conheço e ver como eu vou lidar com isso. Lembrando sempre que a gente tem que traduzir essas perguntas do português do enunciado em condições matemáticas para conseguir resolver o problema”.

Na resolução do exercício mostrado acima, o professor ressalta a diferença entre a "trajetória matemática", que é determinada por uma função de segundo grau, e a "trajetória física", que depende do contexto do problema que está sendo estudado. Ao afirmar que é necessário "combinar equações" o professor ressalta a importância técnica da resolução do problema para conseguir chegar às conclusões físicas do problema.

Resolvendo outro exercício com a mesma temática, ao discutir os resultados na lousa, o professor comentou:

"Se delta for negativo temos que interpretar. Tem $i$ (número imaginário), mas não tem significado físico. Esse tipo de análise ou interpretação em vários problemas de lançamento de projéteis vocês vão ter que fazer. Vocês vão ter que se deparar com uma questão e resolver uma equação de segundo grau, as vezes analiticamente, e vão ter que interpretar essa solução, as vezes para continuar fazendo a conta impondo condições, etc.”.

Novamente, o professor cita a resolução de equações, numericamente ou analiticamente, como atividade importante na resolução dos problemas em física.

Após a resolução dos exercícios e comentários, o professor começou a falar sobre movimento circular uniforme, desenhando na lousa esboços (imagens abaixo) e explicando as equações do movimento: 

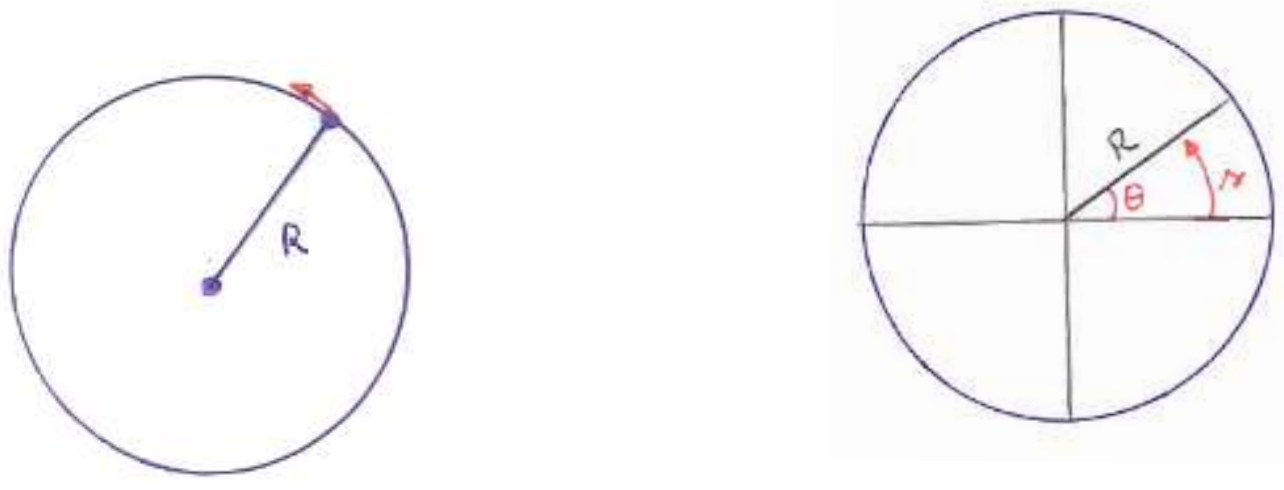

$$
\begin{aligned}
& \theta \rightarrow \operatorname{rad}=\frac{s}{R} \rightarrow s=\theta \cdot R \quad 0 \leq \theta \leq 2 \pi \\
& v=\frac{d S}{d t} \\
& \frac{d S}{d t}=\frac{d(\theta \cdot R)}{d t}=R \cdot \frac{d \theta}{d t} \\
& v=\omega \cdot R \\
& a=\frac{d^{2} S}{d t}=\frac{d v}{d t}=r \frac{d \omega}{d t} \\
& a=\alpha \cdot R \\
& S(t) \rightarrow \theta(t) \\
& \theta=S / R \\
& v(t)=\frac{d S}{d t} \rightarrow \omega(t) \\
& \omega=v / R \\
& a(t)=\frac{d v}{d t} \rightarrow \alpha(t) \\
& \alpha=a / R
\end{aligned}
$$

Equações para o Movimento Circular Uniforme :

$\operatorname{MCU}|v|=c t e, v=$ cte,$\alpha=0$

$$
\begin{gathered}
S=S_{0}+v t \\
\text { R. } \theta=R \cdot \theta_{0}+R \cdot \omega t \\
\theta=\theta_{0}+\omega t
\end{gathered}
$$

Equações para o Movimento Circular Uniformemente Variado:

MCUV a $=$ cte,$\alpha=$ cte

$$
S=S_{0}+v_{0} t+\frac{a t^{2}}{2}
$$




$$
\theta=\theta_{0}+\omega_{0} t+\frac{\alpha t^{2}}{2}
$$

O professor explicou que a descrição vetorial pode ser cartesiana ou em coordenadas polares.

"Cada um desses sistemas tem as suas vantagens e suas desvantagens. A vantagem do sistema cartesiano é que os versores $i$ e $j$ são constantes, quando eu tenho que fazer contas mais complicadas, as derivadas ficam simples, eu só tenho que derivar o ômega, alfa etc. porque o $i$ e $j$ são constantes. Mas a interpretação das respostas é complicada, porque não é fácil imaginar na prática o que uma é expressão 2t na direção $i$, eu preciso desenhar quase esses vetores, dá um certo trabalho tentar entender qual é a direção da velocidade etc. Se eu passo pro sistema de coordenadas polares a interpretação é mais fácil".

Nessa explanação, o professor justificou matematicamente a escolha das coordenadas no estudo do movimento circular em função da facilidade operacional de cada uma e consequentemente das conclusões físicas que elas geram. Ele continuou discorrendo a respeito da mudança de coordenadas:

Cartesiana

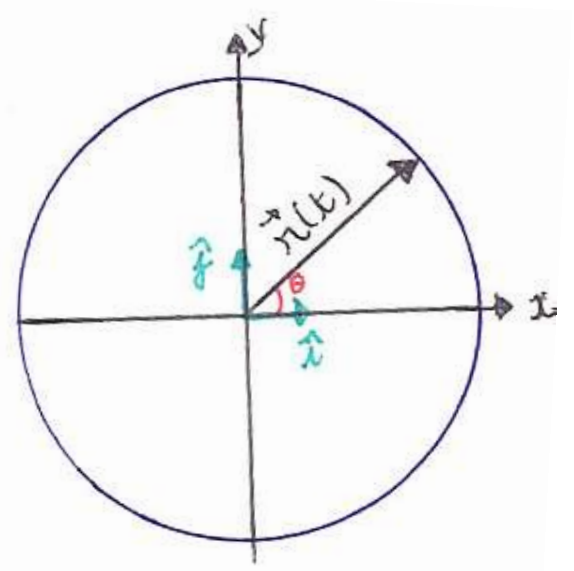

Polar

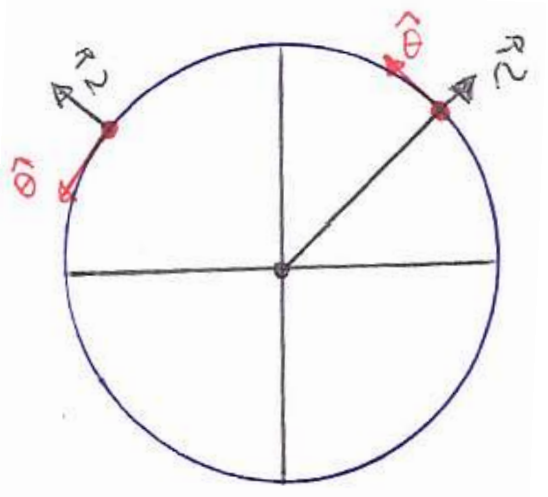

Falando sobre as coordenadas polares, o professor afirma: 
"Se eu tenho uma expressão que só tem uma componente $r$, eu sei que ela é radial, se ela só tem componente $\theta$, eu sei que ela é tangente à trajetória. Em particular, por exemplo, a gente viu que o vetor velocidade é sempre tangente à trajetória. $O$ vetor velocidade descrito nessa notação, vai ser sempre alguma coisa, que pode até ser uma função no tempo complicada, na direção $\theta$ chapéu. É fácil escrever o vetor, eu percebo imediatamente que o vetor velocidade vai ser sempre tangente à trajetória, isso brota, digamos assim, da matemática naturalmente. Enquanto que no caso cartesiano não".

O professor verbaliza a relação entre os símbolos matemáticos nas equações (componente $r$, componente $\theta$ etc.) e as mensagens físicas associadas à esses símbolos. Quando ele afirma que as informações "brotam" da matemática naturalmente é possível perceber a relação entre os códigos matemáticos e os conceitos físicos. A respeito do trabalho operacional na utilização das coordenadas, ele complementa:

"Eu tenho mais trabalho com a conta (coordenadas polares), mas interpreto mais fácil o resultado da conta. Eu tenho mais segurança, menos problema pra fazer conta no sistema cartesiano, mas vou pagar o preço que é ter mais trabalho para interpretar a resposta".

O "ter mais trabalho com a conta" está intimamente relacionado à tarefa instrumental de manipular as equações com o objetivo de estudar fisicamente um problema. Aqui o professor esclarece que a escolha de coordenadas em um determinado contexto geralmente leva em conta a facilidade ou não de operar com as equações matemáticas. Ele ainda ressalta:

"É importante que vocês aprendam as duas formas, nós vamos pular de uma para outra várias vezes (...). Eu estou partindo do 
pressuposto que uma boa parte de vocês viram alguma coisa desse tipo no colegial, isso que eu dei na aula vocês devem ser capazes de fazer esses problemas, esquentar os motores $e$ fazer uma revisão para poder entrar no que realmente é novidade que é forma nova usando $i$, $j$, etc.".

Nesse último trecho descrito no episódio o professor ressalta que acredita que os alunos que cursam a disciplina aprenderam anteriormente no ensino médio muitas das notações e representações citadas até o momento no curso, ou seja, que grande parte das aulas que enfatizam operações matemáticas serve como uma revisão que permite extrapolar o formalismo para as representações que são utilizadas no ensino superior. Não podemos afirmar que os alunos realmente tenham aprendido no ensino médio essas representações. Essa "transição" de representações está presente em grande parte dos comentários e anotações que esse docente apresenta nas aulas assistidas.

\section{Episódio V}

$\mathrm{Na}$ aula VIA, o professor retomou e continuou as explicações sobre o movimento circular. Ele discorreu sobre as coordenadas esféricas:

"Uma esfera é diferente. Numa esfera o movimento circular - a esfera é um corpo tridimensional - você tem que usar $x, y$ e $z$. (...) Eu posso estender com o que a gente chama de sistema de coordenadas esféricas. Essas coordenadas esféricas têm três versores, não mais dois, um na direção radial e dois de outros dois ângulos, fica mais difícil a descrição.(...) Nós vamos ficar aqui, do ponto de vista do curso de vocês, restrito mais ou menos a essa parte de coordenadas polares. Porque vocês estão pouco acostumados a trabalhar ainda com esse monte de senos e cossenos etc. e isso vai ser introduzido direito no curso de eletricidade e magnetismo. Quando vocês forem trabalhar nos primeiros cursos de eletricidade e magnetismo 
vocês vão ver isso de novo, e aí vocês vão ter avançando mais no cálculo, vão ter treinado isso (...)”.

"É mais fácil a gente entender o conceito numa situacão matemática mais simples para depois passar para uma situação matemática mais complicada".

$\mathrm{Na}$ sua fala, o professor ressalta a questão operacional da utilização de determinadas equações e técnicas matemáticas e a existência de uma relação entre a intimidade com essas técnicas e a resolução de problemas em física. Ao afirmar que os alunos vão avançar mais no cálculo no decorrer do curso e terão "treinado" mais, ele explicita que o caráter instrumental e a manipulação das operações matemáticas também são importantes na física, ou seja, que é necessário que os alunos desenvolvam algumas habilidades matemáticas para que consigam compreender alguns conceitos no curso.

Continuando sua explicação, na lousa, o professor deduziu e explicou detalhadamente cada termo das equações abaixo:

$$
\begin{gathered}
v=R\left[\frac{d}{d t} \cos \theta(t)\right] \vec{\imath}+R\left[\frac{d}{d t} \operatorname{sen} \theta(t)\right] \vec{\jmath} \\
=-R \omega \operatorname{sen}\left(\theta_{0}+\omega t\right) \vec{\imath}+R \omega \cos \left(\theta_{0}+\omega t\right) \vec{\jmath} \\
\omega=\frac{d \theta(t)}{d t} \\
v=-R \omega \operatorname{sen} \theta(t) \vec{\imath}+R \omega \cos \theta(t) \vec{\jmath} \\
a=\frac{d \vec{v}}{d t}==-R \omega^{2} \cos \theta+R \omega^{2} \operatorname{sen} \theta(t) \vec{\jmath}=-\omega^{2}(R \cos \theta \vec{\imath}+R \operatorname{sen} \theta \vec{\jmath}) \\
a=-\omega^{2} \vec{r}
\end{gathered}
$$

O professor questionou:

"O que significa fisicamente o sinal negativo? Como sei matematicamente que está para dentro?"

O professor continuou discutindo o uso de diferentes coordenadas no movimento circular uniforme:

"Em determinadas situações pode ser conveniente usar outros sistemas de coordenadas. Por que a gente vai adotar outro sistema de coordenadas? Porque embora as contas fiquem um 
pouco mais difíceis a interpretação do resultado é mais fácil. $\underline{\underline{O}}$ nosso objetivo não é simplesmente escrever alguma coisa e sair fazendo conta, eu quero perceber qual é o movimento. Eu quero saber se o movimento é circular, eu quero saber se o movimento é uniforme, helicoidal, eu quero saber se o movimento é uma elipse etc. eu quero entender o movimento que está sendo descrito por um conjunto de equações, fazer uma visão na minha cabeça - se isso for possível - e se não for possível imaginar, porque pode ser uma curva complicada que a gente não consegue abstrair, imaginar, pelo menos matematicamente extrair informacões que me permitam perceber qual é a direção do movimento, a velocidade ... é isso que a gente quer treinar. Então, pra fazer isso em muitas e muitas circunstâncias usar o sistema de coordenadas polares vai ser mais fácil, eu vou ter mais trabalho com a conta mas vai ser mais fácil interpretar. $E$ a medida que vocês forem ganhando intimidade, digamos assim, com o cálculo diferencial e integral, passando a derivar etc. fazer a conta não vai ser o problema, o problema vai ser mesmo interpretar a resposta, porque aí você tem uma expressão desse tamanho e a gente não consegue entender o que ela diz. Se você consegue transformar uma equação desse tamanho em uma coisa mais compacta aonde o significado dela salta aos olhos é mais fácil a gente perceber o que está acontecendo”.

Nessa fala, o professor ressalta que apesar de ser importante ter intimidade com a parte operacional da matemática para manipular equações e obter informações físicas através delas, o objetivo da física não é simplesmente "fazer conta", ele extrapola essa ação operacional. O "fazer conta" faz parte do aprender e ensinar física e essa habilidade técnica permeia todos os conteúdos e conceitos estudados no ensino superior.

$\mathrm{Na}$ aula, ao falar do movimento circular arbitrário, onde a aceleração tem uma componente tangencial e uma componente radial, o professor questionou: 
"A componente tangencial media o quê? A variação do que? Qual é a interpretação física, o significado dessa componente tangencial da aceleração? O que ela mede?"

As perguntas retóricas foram comuns nos episódios descritos da Turma A, ou seja, perguntas que 0 próprio professor respondia posteriormente ao questionamento exemplificando com as operações matemáticas realizadas na lousa.

\section{Episódio VI}

$\mathrm{Na}$ aula VIIA, o professor faz uma revisão dos conteúdos estudados com exemplos de exercícios. Como as notações matemáticas utilizadas nessa aula são iguais às apresentadas nos episódios anteriores, nesse episódio serão descritos comentários realizados pelo professor que complementam as aulas anteriores e trazem mais informações para a discussão da relação da física com a matemática.

Revisando o estudo do movimento, o professor comentou:

"Por mais facilidade, por menos facilidade de conta, a gente consegue a princípio descrever qualquer movimento possível na natureza. E é claro que a gente não pode fazer isso na base da decoreba de fórmulas, porque como existem infinitos movimentos possíveis nós teríamos que decorar infinitas fórmulas, isto é, seria como jogar xadrez sem entender as regras do jogo, mas só decorando as partidas".

A analogia com o jogo do xadrez ajuda a elucidar que apesar de utilizarmos muitas vezes as mesmas equações ou representações matemáticas em problemas distintos da física, cada problema é uma "partida" e manipular essas equações em seus determinados contextos é saber jogar a partida utilizando suas regras e limitações. O "decoreba de fórmulas" que é comumente criticado também no ensino médio mostra-se ineficaz, pois não abarca todas as possibilidades de aplicações e reflexões que a física oferece.

A respeito do cálculo integral e diferencial, após contar resumidamente a história da construção do cálculo e contextualizar com a história da física com um vídeo, o professor afirma: 
"De forma geral, ele surgiu do contexto da mecânica. Então, introduzir essas ideias no curso de física básica universitário, claro, é fundamental para que vocês inclusive completem o curso de cálculo, porque ele dá, eu acho, a fundamentação intuitiva necessária para que vocês operem".

Nesse trecho o professor "justifica" a inserção das ideias do cálculo e suas operações nas aulas de fundamentos de mecânica (como foi observado nos episódios anteriores) como essencial para que os alunos compreendam também as aulas de cálculo.

Ao revisar velocidade e aceleração, o professor comenta:

"Não existe um significado físico intrínseco ligado ao sinal da velocidade. Do mesmo jeito da aceleração. Uma velocidade ter um sinal positivo ou negativo é uma convenção, ela depende da escolha do sistema de referência. Mas a combinação do sinal da velocidade e da aceleração tem. Se os dois tem o mesmo sinal isso significa que a aceleração está aumentando a velocidade, está ajudando o movimento de um corpo no sentido que ele já está indo, então o movimento é acelerado".

A respeito da interpretação de gráficos, o professor afirma:

"A primeira coisa que eu tenho que fazer quando tem um gráfico é olhar para as legendas, pros eixos e pra escala desse gráfico. $O$ desenho do gráfico não quer dizer nada, se o gráfico é de velocidade por tempo o significado das coisas vai ser completamente diferente se o gráfico é da posição por tempo, ou da aceleração por tempo etc. Eu preciso entender o que aquele gráfico está dizendo, não adianta olhar pra cara do gráfico e sair lá, ligar o piloto automático".

O "ligar o piloto automático" descrito no trecho anterior está relacionado ao caráter puramente instrumental que muitas vezes é utilizado na realização e obtenção de dados de um gráfico. O professor complementa: 
"O importante aqui nessa aula é que vocês entendam bem como é que eu tiro informação do gráfico, como é que essa representação no movimento que nós estamos vendo permite que a gente interprete bem e entenda o que está acontecendo".

$\mathrm{Na}$ leitura de um enunciado de ume exercício de lançamento, o professor comenta:

"Eu tenho que ter sempre essa preocupação. De novo, eu tenho que ter sempre essa preocupação, eu vendo o enunciado do problema, tenho que procurar ver qual é a condição física e consequentemente matemática, que define aquilo que eu to querendo, to perguntando. O que é que define o ponto máximo da trajetória?".

Finalizando sua reflexão sobre as equações matemáticas e o contexto físico que envolve as equações, o professor complementa:

"No fundo é sempre a mesma coisa, quando um problema propõe uma situação a gente tem que parar pra pensar o que que traduz aquela situação do ponto de vista matemático e físico. Que propriedade está por trás daquela pergunta".

Esse episódio ilustra com clareza que o professor segue uma abordagem expositiva e reflexiva em suas aulas, questionando e incitando os seus alunos a refletir sobre as operações matemáticas, seu caráter técnico - operacional e suas implicações físicas.

\subsection{Turma B}

As aulas assistidas na Turma B tinham como principal caraterística uma breve exposição teórica na lousa ou com slides do conteúdo (com equações, esboços de desenhos etc.) e resolução de exercícios entregues pelo professor durante as aulas. Nessas aulas, a apresentação do conteúdo alternava com a resolução do exercício proposto, com um tempo da aula (entre 20 e 30 minutos aproximadamente) destinado exclusivamente para que os alunos resolvessem o problema, solicitando a 
ajuda individual do professor quando era necessário. Após a resolução individual, geralmente o professor realizava a correção comentada do exercício na lousa.

O quadro abaixo sintetiza os conteúdos dos episódios que serão apresentados na sequência:

\begin{tabular}{|c|l|}
\hline Episódios & \multicolumn{1}{|c|}{ Conteúdos } \\
\hline VII & $\begin{array}{l}\text { - Gráfico velocidade por tempo e obtenção do deslocamento; Gráfico } \\
\text { aceleração por tempo; Exercício em aula. }\end{array}$ \\
\hline VIII & $\begin{array}{l}\text { - -Significado da área sobre a curva v(t) e a(t); Exercício em aula: gráfico } \\
\text { aceleração por tempo. }\end{array}$ \\
\hline IX & $\begin{array}{l}\text { - Referência: sistema de coordenadas cartesianas e esféricas; } \\
\text { Operações básicas com vetores; Trabalho para a sala: exercício sobre o } \\
\text { estudo do movimento. }\end{array}$ \\
\hline $\mathrm{X}$ & $\begin{array}{l}\text {-Movimento bidimensional: equação horária, velocidade e aceleração; } \\
\text { Exercício em aula; Lançamento oblíquo. }\end{array}$ \\
\hline $\mathrm{XI}$ & $\begin{array}{l}\text { - Aula de resolução de exercícios: lançamento oblíquo e lançamento } \\
\text { horizontal. }\end{array}$ \\
\hline
\end{tabular}

\section{Quadro VI: Conteúdos dos episódios da turma B - resumo}

\section{Episódio VII}

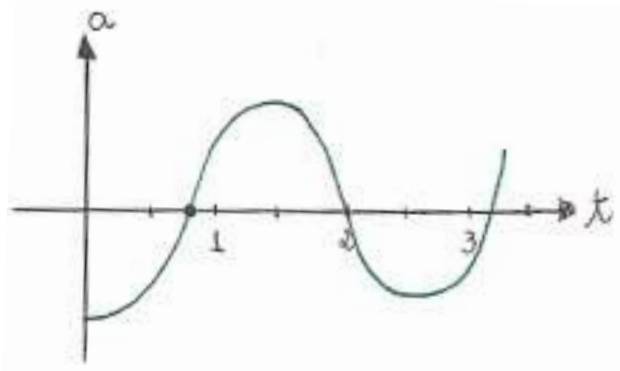

$\mathrm{Na}$ aula IB o professor o professor focou sua explicação no estudo do movimento. Para isso, ele construiu um gráfico velocidade por tempo para explicar o cálculo do deslocamento através do gráfico, ou seja, através da área do gráfico. Nessa explicação, ele questionou aos alunos:

"O que significa área positiva e área negativa? Fisicamente, a área positiva significa que o deslocamento do móvel foi positivo, ou seja, o móvel está se movendo a favor do eixo. Já a área negativa significa que o deslocamento foi no 
sentido oposto à orientação do eixo x. Matematicamente, essa significação não existe, o sentido é puramente físico."

O professor propôs para os alunos fazerem dois exercícios (imagem abaixo). No gráfico posição por tempo ele pediu para calcular a velocidade em alguns pontos através da inclinação da reta tangente à esses pontos e no gráfico velocidade por tempo calcular o deslocamento total do móvel através da área. O professor usou a parte final da aula para que os alunos resolvessem o exercício e não resolveu o exercício na lousa, e sim ajudou individualmente os alunos com dificuldades.
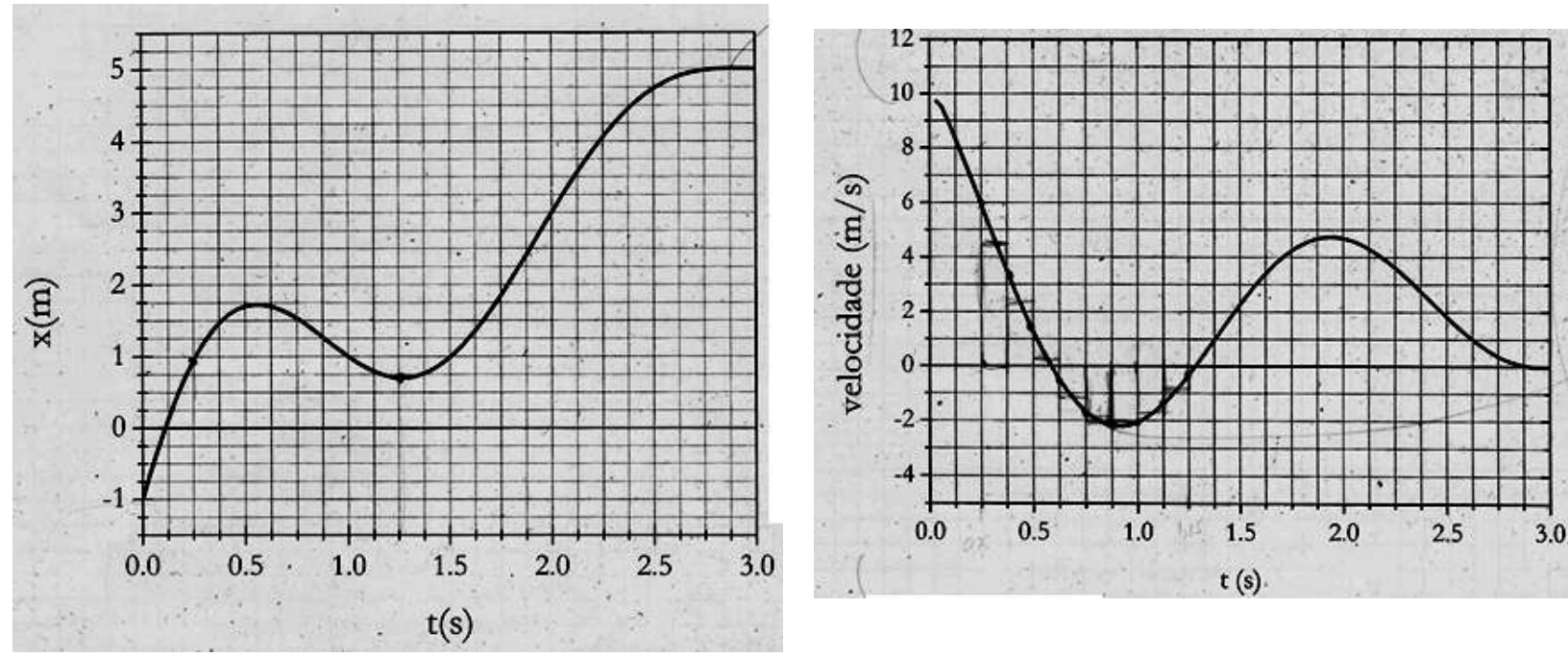

No exercício proposto, é importante notar que o gráfico espaço por tempo é composto por diversas parábolas, o que o diferencia de um exercício presente nas aulas do ensino médio. O gráfico velocidade por tempo também tem essa característica, e a orientação do professor aos alunos foi que para calcular o deslocamento através do gráfico espaço por tempo era necessário aproximar as áreas, ou seja, a ideia de Integral foi utilizada sem que fosse citada essa correspondência pelo professor.

\section{Episódio VIII}

$\mathrm{Na}$ aula IIB, foi apresentado o significado da área sobre a curva $v(t)$ e $a(t)$, realizado comentários sobre a provinha e um exercício em aula: gráfico aceleração por tempo. A figura abaixo mostra um exemplo da explicação do professor sobre como obter 
velocidade através de um gráfico espaço por tempo e como obter aceleração

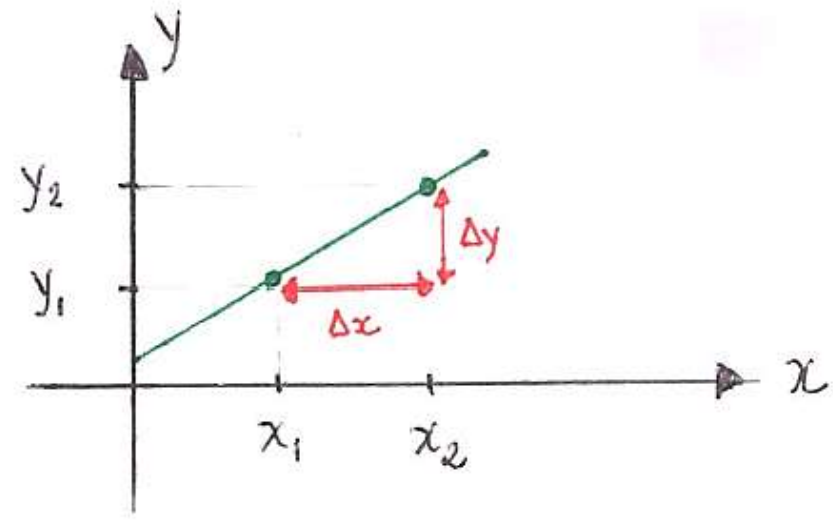
através de um gráfico velocidade por tempo.

$$
x(t) \rightleftarrows v(t)
$$

$$
\begin{gathered}
\frac{\Delta x}{\Delta t} \\
v(t) \rightleftarrows a(t) \\
\frac{\Delta v}{\Delta t} \\
a=\frac{\Delta y}{\Delta x}=\frac{y_{2}-y_{1}}{x_{2}-x_{1}}
\end{gathered}
$$

Nessa aula é importante observar que o professor utiliza a ideia de inclinação da reta para encontrar a velocidade em um gráfico espaço por tempo ou encontrar a aceleração em um gráfico velocidade por tempo. A representação matemática utilizada nesses dois casos é semelhante às representações comumente utilizadas no ensino médio. A notação vetorial e o formalismo mais amplo ainda não haviam sido introduzidos nessas aulas iniciais do curso.

Durante a aula, o professor entregou uma ficha com um exercício para os alunos executarem. Eles tiveram aproximadamente 30 minutos para resolver, sempre com a ajuda do professor quando solicitavam. Após esse tempo, o professor corrigiu o exercício na lousa. Seguem as anotações e comentários da correção do exercício: 
O grífico ao lado representa a accleração de um trem em função do tempo. Sabendo-se que em $t=0, v=0, c x=0$

a) Construa um grifico para v(t).

b) Determine a posicio do trem em $\mathrm{t}=20 \mathrm{~s}, \mathrm{t}=60 \mathrm{~s}$ e $\mathrm{t}=100 \mathrm{~s}$.

c) Construa um grifico para a posiç̃̄o em funçio do tempo.

d) Qüal a-dintuncigperodrida pelo trem durantea movimento? Qual o deslecarminto des taum desde $t=0$ od $t=100 \mathrm{~s}$.

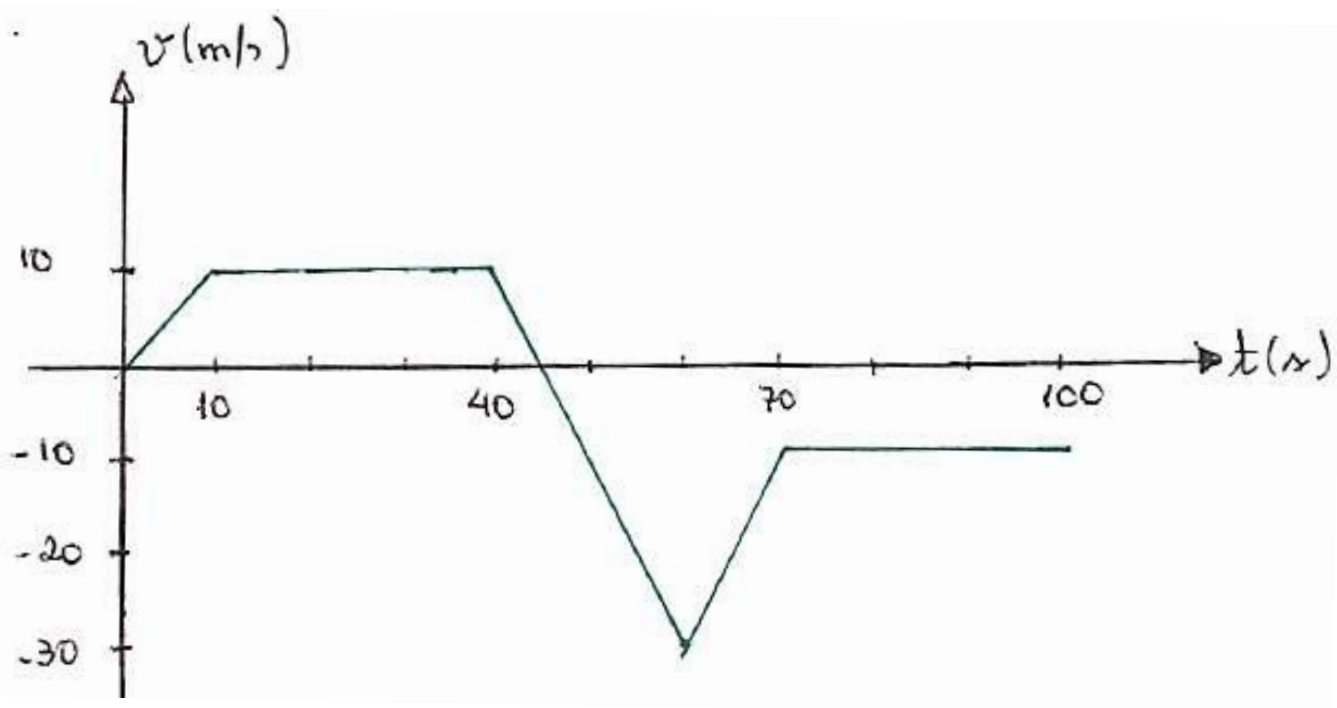

a) Nesse item o professor explicou detalhadamente na lousa o procedimento para calcular a velocidade a partir do gráfico aceleração por tempo, e assim, construir o gráfico representado acima.

b) O professor explicou passo a passo como calcular as posições através do gráfico velocidade por tempo e do cálculo por áreas. A resolução é próxima das resoluções efetuadas nesse tipo de problema pelos alunos no nível médio. 
$S(20 s)=\Delta S=150 m$

$S(45 s)=\Delta S=375 m$

de 45 s a 60 s $\Delta S=-225 m$

$-225 m=S f-375$

$S_{f}=150$

$S(60)=150 m$ de $60 \mathrm{~s}$ a $70 \mathrm{~s} \Delta S=-200 \mathrm{~m}$

$S(70)=-50 m$

de 70 s a $100 s \Delta S=-300 m$

$S(100)=-350 m$

Nos resultados negativos, o professor comentou: "Por que o deslocamento deu negativo? Por que a área embaixo do gráfico é negativa".

c) O gráfico posição em função do tempo foi realizado na lousa (imagem ao lado).

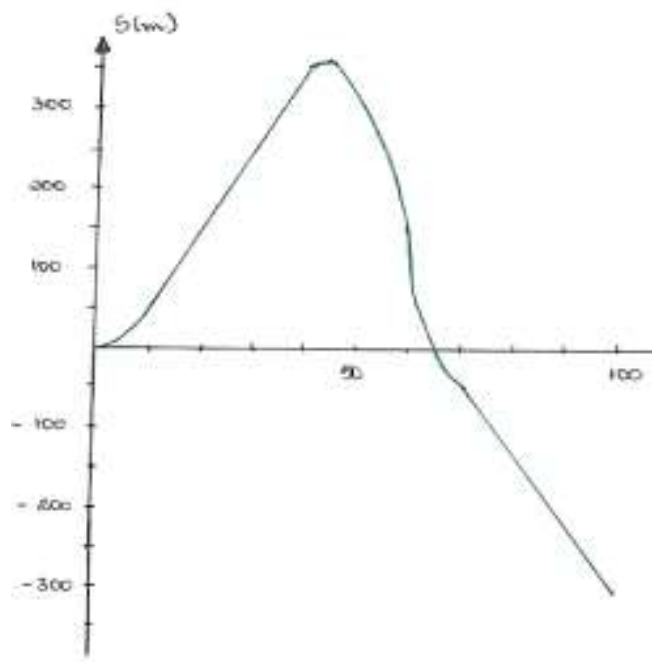
Após inserir os pontos das posições, o professor explicou:

“Como eu ligo os pontos da posição zero à posição 50m? Com uma reta ou uma curva? Eu ligo com uma curva, pois nesse intervalo de tempo a velocidade variou, ou seja, o movimento foi variado. Do tempo $10 \mathrm{~s}$ à $40 \mathrm{~s}$, eu vou ligar com uma reta porque a velocidade foi constante, uniforme".

d) Nesse item o professor calculou a área do gráfico velocidade por tempo para encontrar o deslocamento total, explicando detalhadamente como se calcula a área em cada intervalo.

Nesse episódio de ensino, a aula ficou centralizada na resolução do exercício proposto pelo professor e sua correção na lousa. Uma característica que foi observada nesses primeiros episódios de ensino da Turma B foi a utilização de uma representação matemática na explicação e resolução de problemas semelhante aquela presente no ensino médio. Na correção do exercício o professor explicava detalhadamente operações matemáticas básicas, como o cálculo de áreas, reforçando que essas operações são as mais simples que os alunos precisam 
dominar. Até esse momento, nessas aulas não foi possível identificar a transição de formalismos e representações matemáticas do nível médio para o nível superior.

\section{Episódio IX}

$\mathrm{Na}$ aula IIIB, foi apresentado os diferentes tipos de coordenadas. Primeiramente, as coordenadas cartesianas foram relembradas, para depois discutir, através dos conceitos de latitude e longitude, as coordenadas esféricas (desenhos abaixo). O professor descreveu Referência - sistema de coordenadas cartesianas e esféricas - operações básicas com vetores e realizou um trabalho para a sala: exercício sobre o estudo do movimento.
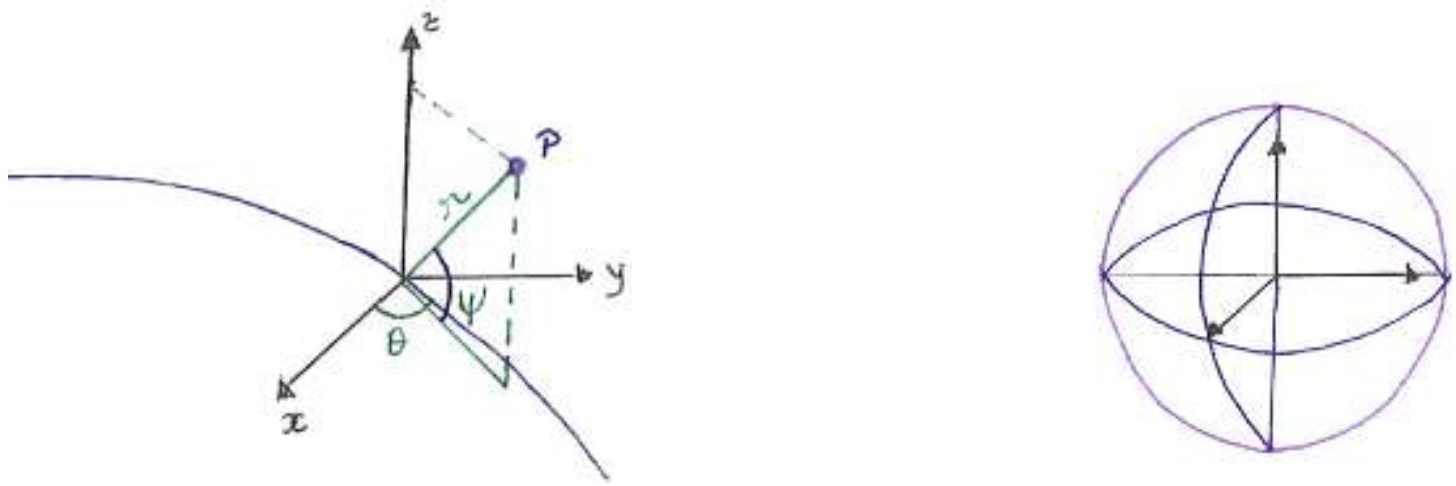

$\mathrm{Na}$ explicação, o professor fez uma revisão sobre vetores e suas operações básicas. Em sua fala, ele citou: "O que você está vendo lá no curso de G.A. (geometria analítica) que parece abstrato, aqui vocês vão ver bem concreto."

Nessa afirmação o professor explicita que a utilização de vetores na física é uma aplicação concreta das operações que os alunos estudam em geometria analítica.

O professor revisou detalhadamente as operações básicas com vetores, como por exemplo, as anotações abaixo: 
Adição gráfica

$$
\vec{a}=5 \vec{\imath}+3 \vec{\jmath}\left\{\begin{array}{c}
|\vec{a}|=\sqrt{5^{2}+3^{2}} \\
|\vec{a}|=\sqrt{34}
\end{array}\right.
$$

$\vec{b}=4 \vec{\imath}-2 \vec{\jmath}$

$\vec{c}=4 \vec{\imath}+0 \vec{\jmath}$

$\vec{d}=0 \vec{\imath}+5 \vec{\jmath}$

$$
\begin{gathered}
\vec{a}=a_{x} \vec{\imath}+a_{y} \vec{\jmath} \\
\vec{b}=b_{x} \vec{\imath}+b_{y} \vec{\jmath} \\
\vec{c}=\left(a_{x}+b_{x}\right) \vec{\imath}+\left(a_{y}+b_{y}\right) \vec{\jmath} \\
\vec{a}=3 \vec{\imath}+5 \vec{\jmath} \\
\vec{b}=4 \vec{\imath}+3 \vec{\jmath}
\end{gathered}
$$

Ao comentar sobre os vetores, o professor afirmou: "Vamos rever bem as operações com vetores para trabalhar com essa ferramenta".

Uma parte da aula o professor destinou para rever as operações básicas vetoriais semelhantes às estudadas pelos alunos no Ensino Médio, no entanto, alguns formalismos novos foram introduzidos nessa aula, como por exemplo, o uso dos versores. Ao afirmar que os alunos vão trabalhar com "essa ferramenta" o professor verbaliza o caráter instrumental que algumas operações matemáticas adquirem no estudo da física.

Ao explicar as posições do móvel no decorrer do tempo e o cálculo da diferença das posições através da subtração vetorial (imagem abaixo), ele citou:

"Agora estamos falando de Física, porque mudando a referência dará o mesmo valor. O que interessa aqui é a métrica, quantas unidades ele tem aqui e quantas unidades ele tem aqui (mostrando o tamanho dos vetores), se eu escolher a origem aqui ou lá não vai fazer a menor diferença, porque vai ser sempre três quadradinhos. O valor e o módulo vai dar sempre o mesmo. Na física a gente trabalha com números, com valores (...)". 


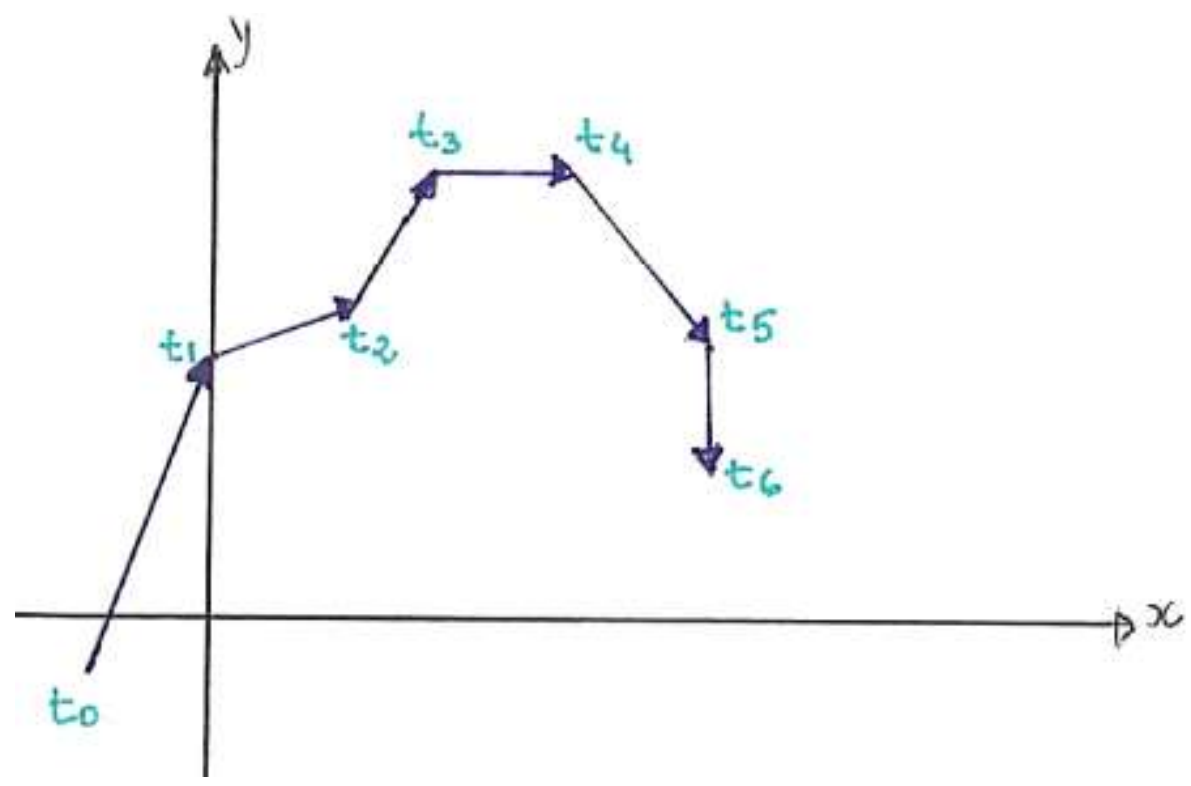

Ao afirmar "agora estamos falando de física" o professor novamente distingue e isola a atuação da matemática nos problemas da física. Quando questionado por um aluno como seria um exemplo de exercício que envolve as operações vetoriais, o professor respondeu:

"Nós já vamos fazer daqui a pouco. Ao invés de ficar aqui só no abstrato vocês vão trabalhar um pouco as aplicações".

Novamente, o professor compreende que a física traz concretude às abstrações matemáticas que os alunos realizam nas operações.

O professor entregou um exercício para os alunos resolverem durante a aula e destinou aproximadamente 35 minutos da aula para a resolução. Durante esse tempo o professor auxiliou individualmente alguns alunos. Após esse tempo o professor corrigiu o exercício na lousa. Segue abaixo essa correção:

\begin{tabular}{|c|c|c|c|}
\hline A tabela ao lado representa a posiçào de um corpo que se move & $t(s)$ & $\mathbf{x}(\mathbf{m})$ & $y(m)$ \\
\hline em um plano, para diferentes instantes. & 0 & -1 & -10 \\
\hline & 10 & 2 & -10 \\
\hline a) Utilize a tabela para construir graficos para $x(t)$ e $y(t)$ & 20 & 4 & -10 \\
\hline b) Construa um gráfico mostrando a trajetória do corpo $(y, x)$ & 30 & 4 & 0 \\
\hline & 40 & 4 & 10 \\
\hline c) Determine o vetor posição para $\mathrm{t}=0 \mathrm{~s} ; \mathrm{t}=20 \mathrm{~s}$ e $\mathrm{t}=50 \mathrm{~s}$ & 50 & 4 & 20 \\
\hline
\end{tabular}

d) Calcule a velocidade média para os seguintes intervalos de tempo, $0 \mathrm{~s}<\mathrm{t}<20 \mathrm{~s}$ e $30 \mathrm{~s}<\mathrm{t}<50 \mathrm{~s}$.

e) Calcule o vetor deslocamento para os mesmos intervalos de tempo do item anterior.

f) Calcule a velocidade média desde $t=0$ até $t=50 \mathrm{~s}$. 
O professor explicou passo a passo a construção dos gráficos abaixo, como por exemplo, a inserção de cada ponto:

a)
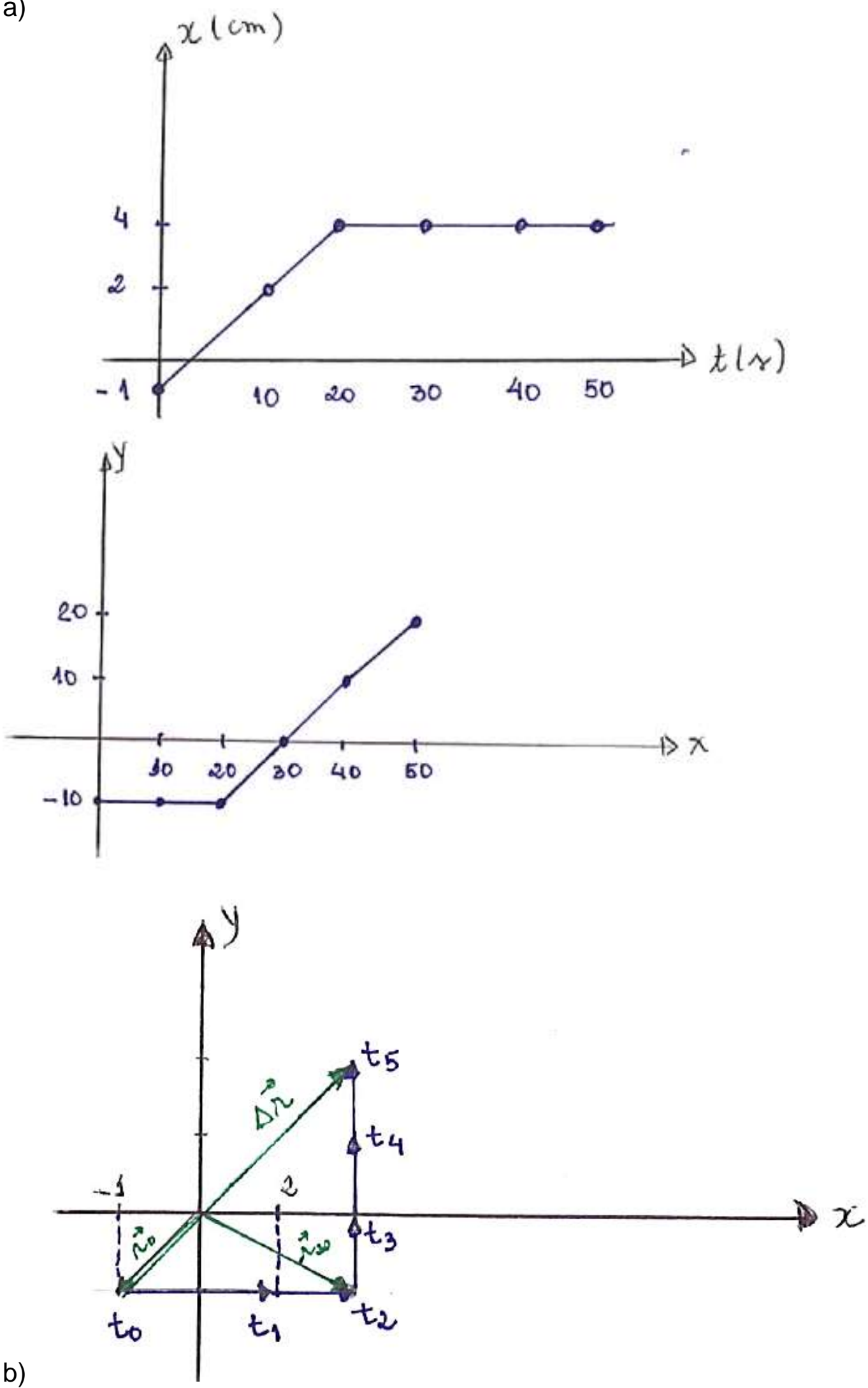
c) Nesse item, o professor ressaltou a importância em se usar a notação vetorial nas representações.

$$
\begin{aligned}
& t=0 s \rightarrow(-1 i-10 j)=\vec{r}_{0} \\
& t=20 s \rightarrow(4 i-10 j)=\vec{r}_{20} \\
& t=50 s \rightarrow(4 i=20 j)=\vec{r}_{50}
\end{aligned}
$$

d)

$$
\begin{gathered}
\vec{v}_{m}(0-20 s)=\frac{\Delta \vec{r}_{0-20}}{20 s}=\frac{\vec{r}_{t=20}-\vec{r}_{t=0}}{20 s} \\
\vec{v}_{m}(0-20 s)=\frac{(4 i-10 j)-(-1 i-10 j)}{20 s} \\
=\frac{(4+1) i}{20 s}+\frac{(-10+10) j}{20 s}=\frac{5}{20} m i+0 j \\
\vec{v}_{m}(0-20 s)=0,25 \mathrm{~m} / \mathrm{s} i \quad \text { "O que significa isso? Que } \\
\vec{v}_{m}=1 / 4 \mathrm{~m} / \mathrm{s} \hat{\imath}(0<\mathrm{t}<20) \longrightarrow \text { nesse intervalo velocidade } \\
\vec{v}_{m}=1 \mathrm{~m} / \mathrm{s} j(30<\mathrm{t}<50) \quad \begin{array}{l}
\text { em y é nula, só tem } \\
\text { velocidade em } x " .
\end{array}
\end{gathered}
$$

e)

$(0<\mathrm{t}<20) \quad \Delta \vec{v}=5 \hat{\imath} m$

$$
(30<\mathrm{t}<50) \quad \Delta \vec{v}=20 j \mathrm{~m}
$$

f)

$$
\begin{gathered}
v_{m}=\frac{5 i-30 j}{50} \\
v_{m}=\frac{1}{10} i+\frac{3}{5} \mathrm{jem} \mathrm{m} / \mathrm{s}
\end{gathered}
$$

No exercício sugerido para os alunos e resolvido na lousa o professor mencionou o significado das respostas dos vetores posição a partir da nova notação utilizada, incitando os alunos a refletir sobre a resposta encontrada.

\section{Episódio X}

$\mathrm{Na}$ aula IVB, o professor realizou uma correção de um exercício, falou do movimento bidimensional: equação horária, velocidade e aceleração, realizou um exercício em aula e explicou Lançamento oblíquo. Na transcrição dessa aula vamos destacar as explicações sobre o movimento que o professor explanou. 
Ao revisar o estudo do movimento, o

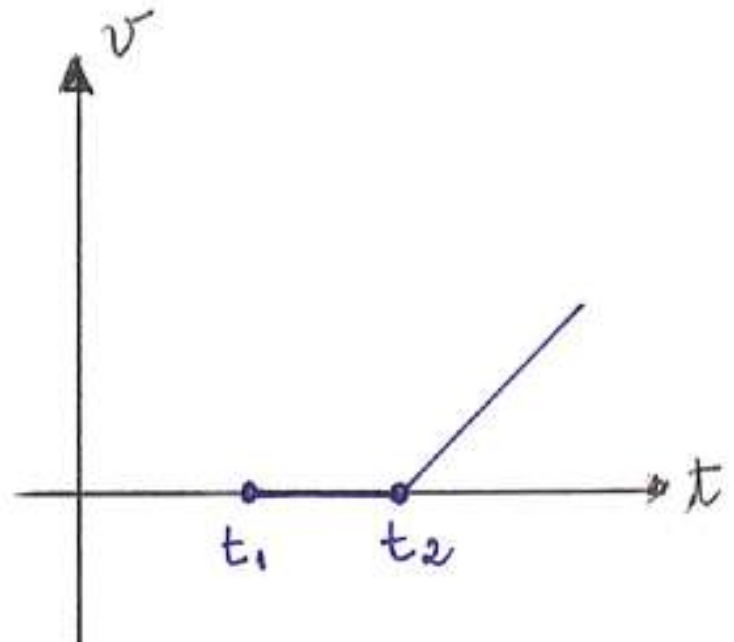
professor realizou alguns gráficos na lousa e teceu comentários. Ao realizar um gráfico velocidade por tempo (imagem ao lado) e discutir sobre a sua construção, o professor comentou:

"Não sabemos se é uma curva, ou uma reta. Tudo depende da aceleração ser constante ou não".

O professor ressalta que existe uma relação matemática entre a constância ou não da aceleração e o "formato" do gráfico, ou seja, a construção do gráfico. Ele continua sua explicação à respeito do assunto com um gráfico espaço por tempo (imagem abaixo):

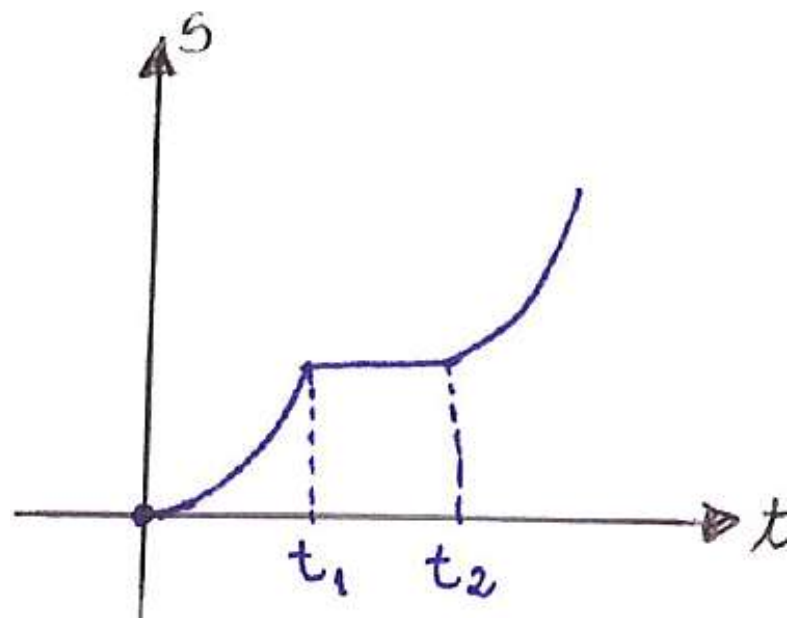

"No gráfico espaço por tempo, entre o tempo zero e $t_{1}$ sabemos que é uma curva pois o movimento é variado, ou seja, é uma função de segundo grau".

Nessa explicação o professor relaciona diretamente as funções com o estudo do movimento, e utiliza os conhecimentos matemáticos para analisar a construção do gráfico.

Ao retomar o estudo dos movimentos bidimensionais, o professor constrói um gráfico para explanar o vetor posição e sua correta descrição (imagem abaixo): 


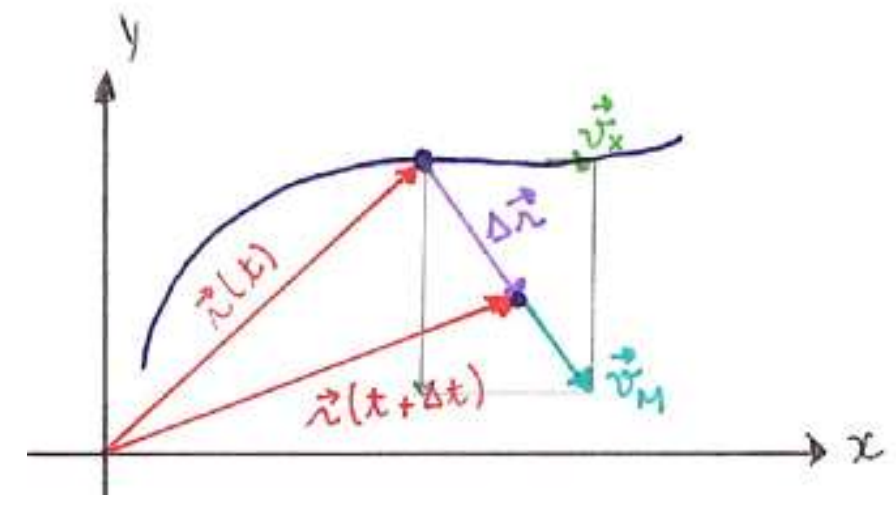

"Aqui vamos realizar uma descrição vetorial. Tem que tomar cuidado com as notações utilizadas, existe um rigor para a representação".

O professor explica nesse momento a diferença entre uma descrição que não é vetorial e uma descrição vetorial, ressaltando que a representação matemática é muito importante para a interpretação das informações que o problema possui.

\section{Episódio XI}

$\mathrm{Na}$ aula VB, o professor realizou três exercícios de lançamentos, destinando o começo da aula para que os alunos resolvessem sozinhos e o término para a resolução na lousa. Abaixo são descritas alguns momentos da resolução de exercícios com comentários que o professor realizou a respeito deles.

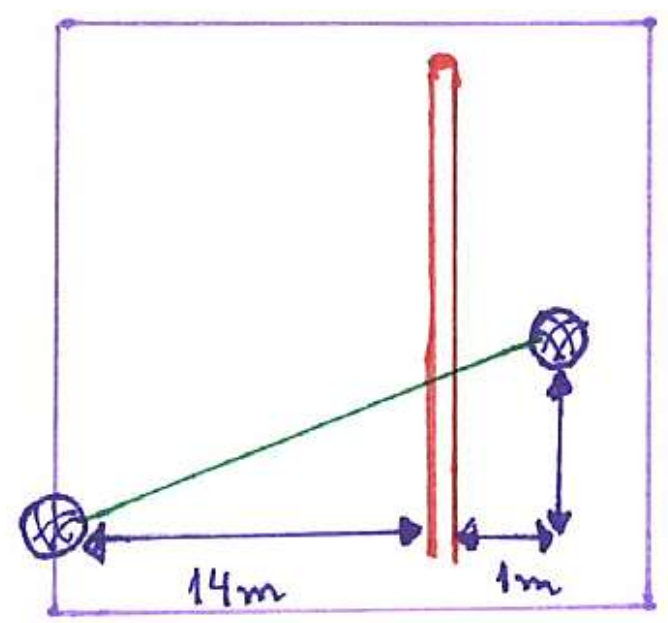

No primeiro exercício tem-se o lançamento de uma bola que vai atravessar uma rede que está à $14 \mathrm{~m}$ de distância do lançamento. $O$ desenho ao lado reproduz o desenho da aula. O professor escreve na lousa as equações "base" para os alunos resolverem o problema:

$$
\begin{gathered}
x(t)=0+v 0 \cdot \cos \theta t \\
x(t)=v 0 \cdot \cos \theta t
\end{gathered}
$$




$$
\begin{aligned}
& y(t)=0+v o \cdot \operatorname{sen} \theta t-g t^{2} / 2 \\
& v y(t)=v o \cdot \operatorname{sen} \theta-g t
\end{aligned}
$$

$\mathrm{Na}$ construção dessas equações, o professor explica a relação da referência com o sinal negativo da gravidade e porque as posições iniciais da bola são nulas na referência adotada. Após a escrita das equações, o professor corrige o exercício inserindo os dados numéricos nas equações e realizando as operações.

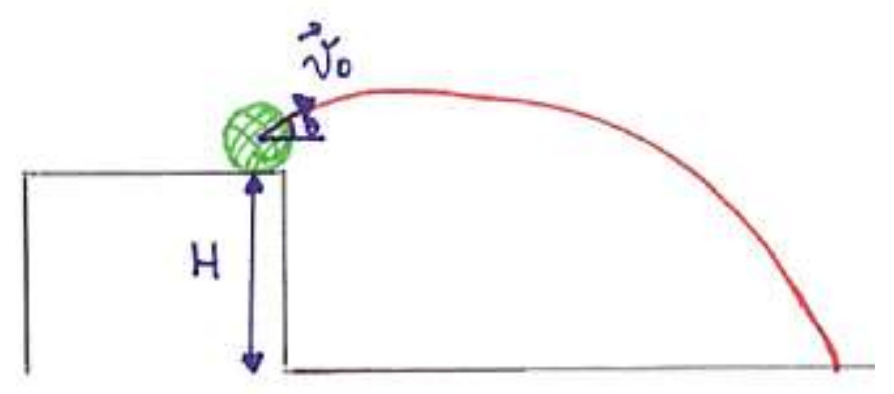

O segundo exercício, o professor realiza na lousa um problema de lançamento horizontal (imagem ao lado) e também explana as equações necessárias para o seu estudo e a relação dessas equações com a referência adotada. Após essa explanação, o professor explica que é necessário somente aplicar os valores numéricos nas equações para encontrar as respostas, ressaltando que os problemas de lançamento são muito parecidos, ou seja, é necessário somente escrever as equações horárias de acordo com o referencial adotado que a "base" para a resolução já está pronta.

É possível perceber nesses dois exemplos que foram realizados na aula que as notações utilizadas são análogas às que são comumente utilizadas no ensino médio no estudo dos lançamentos. Nesse episódio foi destacada a ação de resolver problemas "tipo" seguindo um procedimento comum de resolução.

\subsection{Abordagem por conteúdos - Turma A e Turma B}

Para facilitar uma visão mais precisa das abordagens e ênfases presentes nas duas turmas nos episódios apresentados, construiu-se um quadro comparativo entre as turmas por conteúdos, métodos de explicação e/ou conceitos abordados nos assuntos que foram mais recorrentes no estudo de caso. É importante ressaltar que esse olhar é específico para os episódios que estão explícitos na dissertação, por isso, não podemos afirmar que se alguns aspectos não foram trabalhados 
nesses episódios eles não foram trabalhados também em outros momentos que não estão documentados.

\begin{tabular}{|c|c|c|}
\hline Conteúdo & & \\
\hline $\begin{array}{l}\text { Equações do } \\
\text { movimento }\end{array}$ & $\begin{array}{l}\text { Professor define a equação } \\
\text { como uma função } \\
\text { utilizando limite. Ex.: } \\
\qquad x(t)=x_{0}+v \cdot t \\
x(t)=\lim _{\Delta t \rightarrow 0} \frac{x(t+\Delta t)-x(t)}{\Delta t} \\
\text { (Episódio I) }\end{array}$ & $\begin{array}{l}\text { Professor explica o cálculo do } \\
\text { deslocamento através da área do } \\
\text { gráfico velocidade por tempo, sem } \\
\text { utilizar a notação do cálculo } \\
\text { (integral). (Episódio VII). Professor } \\
\text { apresenta a equação horária do } \\
\text { espaço sem utilizar conceitos do } \\
\text { cálculo. (Episódio VIII). Ex.: } \\
\qquad \frac{\Delta x}{\Delta t}=v(t)\end{array}$ \\
\hline $\begin{array}{ll}\text { Gráficos } & \text { do } \\
\text { estudo } & \text { do } \\
\text { movimento } & \end{array}$ & $\begin{array}{l}\text { Professor apresenta os } \\
\text { gráficos na lousa e realiza } \\
\text { discussões a respeito deles. } \\
\text { Os alunos não constroem } \\
\text { gráficos na aula. (Episódio I) } \\
\text { Ex.: }\end{array}$ & $\begin{array}{l}\text { Professor constrói gráfico } \\
\text { velocidade por tempo na lousa e } \\
\text { alunos realizam exercícios sobre o } \\
\text { tema. Alunos são orientados passo } \\
\text { a passo sobre a construção de } \\
\text { gráficos durante a correção dos } \\
\text { exercícios (Episódio VII, VIII e IX). } \\
\text { Ex.: }\end{array}$ \\
\hline
\end{tabular}




\begin{tabular}{|c|c|c|}
\hline $\begin{array}{l}\text { Definição de } \\
\text { velocidade }\end{array}$ & 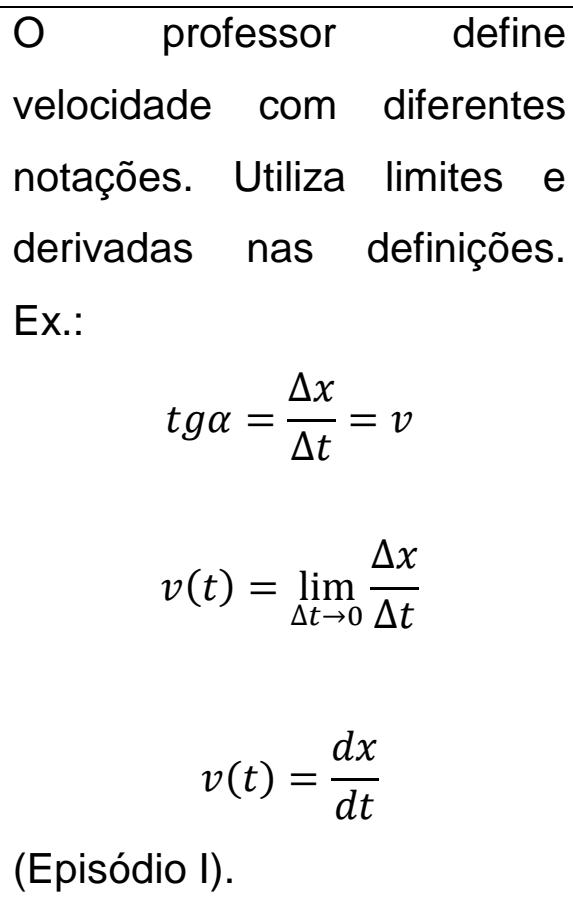 & $\begin{array}{l}\text { O professor define velocidade } \\
\text { somente com uma expressão. Ex.: }\end{array}$ \\
\hline $\begin{array}{l}\text { Movimento } \\
\text { bidimensional }\end{array}$ & $\begin{array}{l}\text { Professor define movimento } \\
\text { bidimensional e explica } \\
\text { detalhadamente a notação } \\
\text { vetorial. Ele revisa como } \\
\text { fazer operação com vetores. } \\
\text { (Episódio II) Ex.: }\end{array}$ & $\begin{array}{l}\text { Professor apresenta as } \\
\text { coordenadas cartesianas } \\
\text { esféricas. Ele também conceituou } \\
\text { vetores e explicou detalhadamente } \\
\text { as operações vetoriais. (Episódio XI } \\
\text { e X). Ex.: }\end{array}$ \\
\hline $\begin{array}{l}\text { Conceito de } \\
\text { aceleração }\end{array}$ & $\begin{array}{l}\text { Professor define com } \\
\text { diferentes notações } \\
\text { matemáticas, inclusive com } \\
\text { limite e derivada. (Episódio } \\
\text { III) Ex.: } \\
\vec{a}(t)=\lim _{\Delta t \rightarrow 0} \frac{\Delta \vec{v}}{\Delta t} \\
=\lim _{\Delta t \rightarrow 0} \frac{\vec{v}(t+\Delta t)-\vec{v}(t)}{\Delta t}=\frac{d \vec{v}}{d t}\end{array}$ & $\begin{array}{l}\text { (Episódio VIII) Professor define com } \\
\text { o cálculo com uma notação } \\
\text { matemática - função - e através de } \\
\text { um gráfico velocidade por tempo. } \\
\text { Ex.: } \\
\qquad a=\frac{\Delta y}{\Delta x}=\frac{y_{2}-y_{1}}{x_{2}-x_{1}}\end{array}$ \\
\hline
\end{tabular}




\begin{tabular}{|c|c|c|}
\hline $\begin{array}{l}\text { Exemplos de } \\
\text { movimentos: } \\
\text { estudo dos } \\
\text { lançamentos }\end{array}$ & $\begin{array}{l}\text { Professor faz a dedução de } \\
\text { equações literais de um } \\
\text { lançamento oblíquo e } \\
\text { realizou um exercício na } \\
\text { lousa substituindo valores } \\
\text { numéricos nas equações } \\
\text { deduzidas. (Episódio III). Ex.: } \\
\qquad H_{\max }=\frac{1}{2} \frac{v_{0}^{2} \operatorname{sen}^{2} \theta}{g}\end{array}$ & $\begin{array}{l}\text { Professor resolveu um exercício na } \\
\text { lousa deduzindo equações para o } \\
\text { lançamento oblíquo os alunos } \\
\text { resolverem problemas substituindo } \\
\text { valores numéricos nas equações } \\
\text { deduzidas. (Episódio XI). Ex.: }\end{array}$ \\
\hline $\begin{array}{l}\text { Movimento } \\
\text { circular }\end{array}$ & 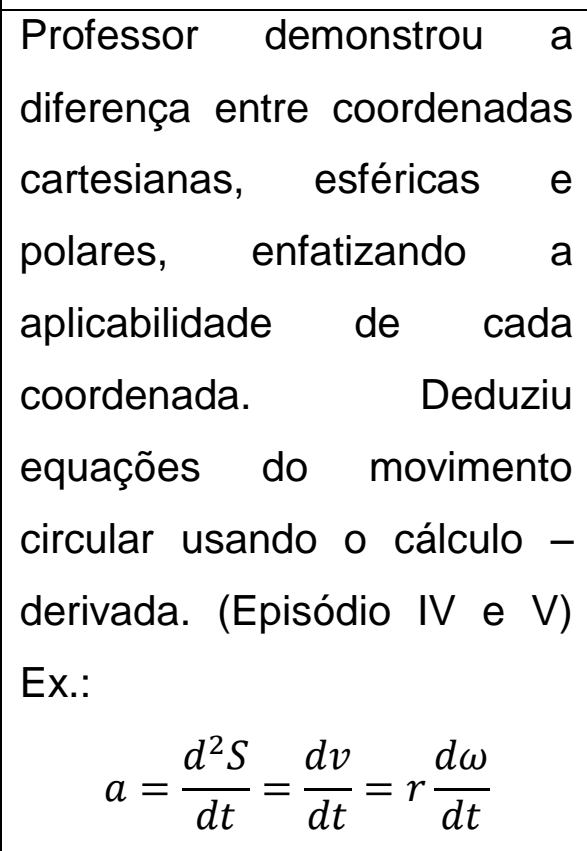 & $\begin{array}{l}\text { Esse conteúdo não está presente } \\
\text { nos episódios explicitados nesse } \\
\text { trabalho. }\end{array}$ \\
\hline
\end{tabular}

\section{Quadro VII: Comparação entre turmas - conteúdos e abordagens}

Observando os episódios e a tabela sintetizadora podemos perceber que 0 professor da Turma A inseriu, desde o início das suas explicações e explicitações, o cálculo diferencial e as notações do cálculo para ensinar os primeiros conceitos da mecânica. Já o professor da Turma B, apesar de utilizar a ideia de cálculo de áreas em gráficos, por exemplo, optou por não fazer essa inserção formal (com notações e justificativas do cálculo para as equações utilizadas) nas primeiras aulas do seu curso de fundamentos de mecânica. Essa distinta escolha dos docentes caracteriza as turmas com dois cursos diferentes, mas que seguem o mesmo conteúdo 
programático proposto pela universidade. No próximo capítulo vamos analisar outros aspectos que foram observados no estudo de caso apresentado. 


\section{Capítulo 5}

\section{Caráter técnico e relacional da relação da física com a matemática em um curso de licenciatura em física}

Como citado anteriormente, o estudo de caso foi realizado com duas turmas distintas, com professores diferentes. Não é o intuito desse trabalho generalizar o curso ministrado por esses professores, pois, como foi possível observar, o estudo de caso trata-se de uma amostra das aulas do curso de fundamentos de mecânica e não representa todo o curso. Além disso, são apresentadas visões previamente "recortadas" em episódios e outros aspectos das aulas, como por exemplo, utilização dos livros, auxílio de monitores etc. não foram analisados, assim como as avaliações realizadas por esses alunos.

Observando os episódios apresentados anteriormente é possível perceber claramente que, nas aulas e conteúdos selecionados para o estudo de caso, os dois professores possuem abordagens diferentes e o curso das aulas seguem "roteiros" distintos. Ao iniciar o estudo de caso não era possível prever quais as diferenças das abordagens, pois a escolha priorizou o curso a ser analisado (fundamentos de mecânica) e não os docentes responsáveis em lecionar a disciplina. Acreditamos que essas diferenças contribuem para a discussão presente nessa pesquisa, pois apresentam duas óticas diferentes sobre um mesmo curso e conteúdo, que para a nossa análise parecem complementares.

Não é o objetivo também da pesquisa generalizar os cursos introdutórios da mecânica na graduação em universidades em geral, já que como comentado anteriormente os dados colhidos são insuficientes para conclusões amplas e abrangentes. O principal objetivo desse estudo de caso é exemplificar com aulas reais como as relações da física com a matemática podem ser apresentadas explicitamente pelos professores em um curso inicial de licenciatura em física. Os exemplos levantados nesse capítulo contextualizam as reflexões feitas anteriormente sobre as discussões teóricas existentes sobre a temática desse trabalho. 
No capítulo 2 foi apresentada uma tabela (KARAM, 2012) que exemplifica aspectos que caracterizam o uso da matemática no ensino de física em duas vertentes não excludentes: caráter técnico/instrumental/procedimental e caráter estrutural/relacional/organizacional. Alguns desses exemplos foram observados no estudo de caso realizado e sintetizados nas próximas seções desse capítulo.

\subsection{Caráter técnico da relação da física com a matemática}

Nessa seção apresentamos observações realizadas nos episódios de ensino de aspectos que estão relacionados com o caráter técnico da relação da física com a matemática, como as diferentes notações utilizadas, citações explícitas sobre esse caráter e interferência de cursos ligados à matemática no curso de Fundamentos de Mecânica.

\section{a) Transitividade das notações matemáticas}

A ideia da utilização da matemática como representação de ideias e grandezas da física também pode ser classificada como procedimental, afinal, é possível utilizar signos e símbolos diferentes para representar uma mesma grandeza, assim como é possível encontrar resultados iguais manipulando equações matemáticas diferentes.

Nos episódios de ensino estudados podemos perceber que em um contato inicial do estudo do movimento foram apresentados formalismos matemáticos diferentes para representar um mesmo conceito: o cálculo da velocidade através de uma função de primeiro grau (semelhante ao apresentado no Ensino Médio), através do coeficiente angular da reta em um gráfico espaço por tempo (também presente nos materiais didáticos do Ensino Médio) e o cálculo através de limites e derivadas (com um formalismo presente no ensino superior).

A transição de formalismos e representações representa de certa forma a transição de nível de ensino que esses alunos passam ao iniciar seus estudos na graduação. Conseguimos perceber claramente nas falas do professor da Turma A as justificativas para tais transições, tais como a possibilidade de extrair mais informações físicas das representações matemáticas e a possibilidade de estudar movimentos mais complexos com formalismos mais consistentes. A preocupação em resolver alguns exercícios seguindo o "molde" comumente observado no ensino 
médio foi observada em algumas explicações do professor da Turma B, demonstrando que problemas resolvidos no ensino superior em algumas situações podem ser simplificados e manipulados com um formalismo mais simples e objetivo.

\section{b) Aspecto operacional da matemática}

Em algumas citações do estudo de caso, foi possível perceber 0 caráter operacional/ferramental ou técnico que a matemática muitas vezes apresenta nas aulas de física. Por exemplo, no Episódio $\mathrm{V}$ quando o professor afirmou:

“ (...) Porque vocês estão pouco acostumados a trabalhar ainda com esse monte de senos e cossenos etc. e isso vai ser introduzido direito no curso de eletricidade e magnetismo. Quando vocês forem trabalhar nos primeiros cursos de eletricidade e magnetismo vocês vão ver isso de novo, e aí vocês vão ter avançando mais no cálculo, vão ter treinado isso (...)".

A palavra "treinar" refere-se ao ato de repetir sistematicamente uma ação até dominá-la completamente (chamado por alguns autores, como explicitado no capítulo 2 , de "matematização"), ou seja, refere-se a um caráter operacional que os alunos têm ou vão adquirir no decorrer do curso de graduação.

No episódio IX, no comentário "Vamos rever bem as operações com vetores para trabalhar com essa ferramenta" o professor explicita verbalmente que as operações matemáticas com vetores que ele vai revisar servem como instrumento ferramental para os conceitos que ele vai estudar, ou seja, que o professor enxerga um caráter operacional da matemática na física nesse momento.

Conseguimos perceber também que ambos professores ressaltam a importância em saber operar matematicamente equações, escrever representações matemáticas diferentes e dominar técnicas de cálculo para avançar no estudo da física. Em alguns momentos, como na resolução de exercícios, os professores explicam que o conhecimento matemático é importante para aprofundar a física. Sobre essas mesmas ideias no nível médio de ensino, CARMO (2006) comenta: 
"Ao conversar com professores de Física do ensino médio é muito comum reclamações sobre a falta de conhecimento de conteúdos matemáticos pelos seus alunos. Eles ainda argumentam que isso impede o aprofundamento dos conhecimentos físicos". CARMO (2006: 1)

Como comentado em PIETROCOLA (2002) e KARAM (2012), afirmar que a falta de habilidades matemáticas impede totalmente a aprendizagem em física é um argumento ingênuo. No entanto, é possível afirmar que em determinados conhecimentos físicos, o nível de conhecimento matemático interfere na compreensão dos conhecimentos da física e por isso não podemos desprezar o caráter operacional/ferramental e técnico da matemática na física. Compreendemos aqui que a função instrumental da matemática não pode ser entendida como desprezível e repudiada, mas sim, como importante na construção do conhecimento da física. O que acreditamos é que a utilização exclusiva da matemática com esse perfil nas aulas é que compromete o aprendizado.

\section{c) Relações com outros cursos da licenciatura}

$\mathrm{Na}$ grade curricular da licenciatura em física da Universidade de São Paulo (USP) as disciplinas de Cálculo para Funções de uma Variável Real I e Geometria Analítica são oferecidas concomitantemente com a disciplina Fundamentos de Mecânica, no primeiro semestre da graduação.

O conteúdo programático ${ }^{4}$ do curso de cálculo nessa universidade é:

"Equações e inequações; definição de função e gráficos; funções polinomiais de primeiro e segundo graus; funções modulares; funções inversíveis; funções exponenciais e logarítmicas; funções trigonométricas e suas inversas. Taxa de variação, velocidade, coeficiente angular da reta tangente; o conceito de derivada em um ponto; a função derivada; aproximações e linearidade local; conceitos intuitivo e definições de limite, de continuidade e de diferenciabilidade; regras de derivação. O Teorema do Valor Médio e suas

\footnotetext{
${ }^{4}$ Disponível em:

https://uspdigital.usp.br/jupiterweb/obterDisciplina?sgldis=MAT1351\&codcur=43031\&codhab=1
} 
aplicações. O comportamento de uma função: um estudo qualitativo; o gráfico de uma funções, comportamento no infinito, regras de L'Hospital. Problemas de otimização. Aproximação de funções: fórmula de Taylor com resto de Lagrange"

Nesse cronograma, os alunos não tem no primeiro semestre um contato com o conceito de Integral, que é utilizado no estudo da Mecânica.

Durante as aulas assistidas no estudo de caso, os alunos estavam aprendendo em cálculo as definições e aplicações de limites, no entanto, não haviam estudado ainda o conceito de derivada.

No curso de Geometria Analítica, o conteúdo programático ${ }^{5}$ é o seguinte:

"Coordenadas no plano: coordenadas cartesianas retangulares no plano; distância entre dois pontos; equação de uma circunferência; posição relativa de duas circunferências; coordenadas polares. Vetores no plano; componentes de um vetor; adição de vetores; multiplicação de um vetor por um número real; vetores linearmente independentes e linearmente dependentes; produto escalar. Estudo da reta no plano: equação geral da reta; Paralelismo e perpendicularismo; ângulo; distância de ponto a reta. Secções cônicas: equações na forma reduzida em coordenadas cartesianas e polares; mudança de coordenadas no plano; classificação das cônicas. Vetores no espaço; coordenadas cartesianas retangulares no espaço; distância entre dois pontos; componentes de um vetor; adição e multiplicação por escalar; vetores l.i. e I.d.; produtos escalar, vetorial e misto. Estudo da reta e do plano no espaço; equação do plano; paralelismo e perpendicularismo entre planos; equações de uma reta no espaço; posições relativas; ângulos; distâncias. Estudo das superfícies quádricas;

\footnotetext{
${ }^{5}$ Disponível em:

https://uspdigital.usp.br/jupiterweb/obterDisciplina?sgldis=MAT0105\&codcur=43031\&codhab=1
} 
equações na forma reduzida; mudança de coordenadas no espaço; classificação de quádricas".

Durante as aulas assistidas no estudo de caso, os alunos estavam aprendendo em geometria analítica vetores e operações com vetores. As mudanças de coordenadas, por exemplo, que foram muito citadas nos episódios, ainda não haviam sido apresentadas no curso regular de geometria analítica.

Sobre a relação entre as disciplinas matemáticas cursadas na graduação e as disciplinas de física, PEREIRA (2005) afirma:

$\mathrm{Na}$ maioria das instituições brasileiras de ensino superior, as disciplinas de Física e de Cálculo são ministradas simultaneamente. Embora esta prática tenha certas vantagens, apresenta as seguintes desvantagens: em Física, sob o argumento de que o instrumental matemático ainda não foi visto, os problemas cujas resoluções exijam o uso do Cálculo são omitidos; em Cálculo, por sua vez, não há interesse em usar parte do tempo na resolução de problemas físicos. Deste modo, estabelece-se um distanciamento entre o ensino de Física e de Cálculo. PEREIRA (2005:2)

Nos episódios de ensino observados nessa pesquisa, podemos perceber que principalmente na Turma $A$, a constatação que PEREIRA traz em sua citação a respeito da omissão de problemas com cálculo nas aulas de física não foi verificada: o professor da Turma A muitas vezes explicava os "procedimentos matemáticos" de cálculo de limites e derivações para explicar a relação desses procedimentos com os conceitos físicos estudados. Além disso, foi possível perceber também essa mesma ação com conteúdos do curso de geometria analítica, como a operação com vetores e mudança de coordenadas.

$\mathrm{Na}$ Turma B, o professor concentrou o estudo inicial do movimento com notações utilizadas comumente no nível médio (funções e gráficos de funções). $\mathrm{Na}$ resolução de exercícios, o professor apresentou o cálculo do deslocamento de um corpo, por exemplo, através do cálculo dá área de um gráfico velocidade por tempo (que advém do conceito de Integral). Apesar de citar a ideia de Integral (que é aprendida de acordo com o conteúdo programático da licenciatura no curso de Cálculo para Funções de uma Variável Real II), a notação e representação matemática utilizada foi o cálculo das áreas (utilizando aproximações, por exemplo). 
Em comum com o professor da Turma A, o professor da Turma B também fez uma ampla explicação durante suas aulas sobre vetores, suas operações e notações e sobre a mudança de coordenadas.

Nos exemplos apresentados no nosso estudo de caso, ao contrário também do comentário exposto por PEREIRA, conseguimos enxergar com clareza uma tentativa de aproximação do ensino de física, cálculo e geometria analítica, às vezes de maneira explícita e sistemática (mais frequente na Turma A) e em outras mais sutilmente (Turma B). Essa tentativa de aproximação ocorreu quando os professores precisaram explicar conteúdos dessas disciplinas para utilizá-los nas suas explicações dos conteúdos físicos.

\subsection{Caráter relacional da matemática na física}

Nas aulas de fundamentos de mecânica selecionadas para análise podemos destacar também exposições explícitas dos docentes das disciplinas que remetem a aspectos que caracterizam o caráter relacional e organizacional que a matemática tem no ensino e aprendizagem da física. Essas exposições estão sintetizadas na seção a seguir.

\section{a) Interpretação, Significação e Abstração}

Podemos destacar algumas exposições explícitas que fazem referência a uma ação mental que os estudantes devem realizar no estudo da física: a interpretação. Em alguns episódios os alunos são incitados a interpretar números, sinais, gráficos e símbolos e essa ação de pensar o resultado ou o que o a matemática fornece extrapola o caráter instrumental/ferramental que a matemática muitas vezes utiliza na física.

No Episódio I, por exemplo, o professor comenta sobre a interpretação de uma função na física:

“ $x(\mathrm{t})$ é uma função, que é contínua no tempo e só faz sentido com um sistema de referência, ou seja, depende do referencial que eu escolho. Essa função é difícil interpretar. Onde o corpo para? Está indo para trás ou para frente?" Ep.I

Essa interpretação depende da equação utilizada e dos seus resultados numéricos. Os números respondem sobre o movimento, na função horária da 
velocidade um sinal indica um movimento favorável ou contrário a um referencial adotado. No episódio V, em uma aula sobre movimento circular uniforme, o professor comenta:

"A componente tangencial media o quê? A variação do que? Qual é a interpretação física, o significado dessa componente tangencial da aceleração? O que ela mede?" Ep. V

Nesse exemplo, o questionamento sobre a interpretação física é direto e explícito. O professor demonstra a componente tangencial da aceleração matematicamente e questiona sobre o seu significado. Voltando no episódio I, o professor indaga:

\section{“Qual é a interpretação geométrica do gráfico?” Ep. 1}

Um gráfico, na física, permite uma interpretação geométrica e um significado físico. Esse questionamento ressalta que as interpretações são distintas dependendo do olhar: o olhar matemático ou o olhar físico. Mas as interpretações estão, em um contexto físico, interligadas. Outro exemplo ocorreu no episódio VI:

"A primeira coisa que eu tenho que fazer quando tem um gráfico é olhar para as legendas, pros eixos e pra escala desse gráfico. desenho do gráfico não quer dizer nada, se o gráfico é de velocidade por tempo o significado das coisas vai ser completamente diferente se o gráfico é da posição por tempo, ou da aceleração por tempo etc. Eu preciso entender o que aquele gráfico está dizendo, não adianta olhar pra cara do gráfico e sair lá, ligar o piloto automático". Ep. VI

Nessa citação, o professor ressalta que um mesmo "desenho" em um gráfico (mesma interpretação matemática) pode ter significados distintos fisicamente. $\mathrm{Na}$ análise de um problema desse tipo, o gráfico fornece informações fundamentais para a interpretação do problema (os valores numéricos, se é linear, parabólico etc.), ou seja, a interpretação matemática é de suma importância. Mas, sem uma interpretação física (verificação dos eixos, tipo de movimento etc.) não é possível compreender o problema. As interpretações são diferentes - a matemática e a física - mas a interpretação física depende da interpretação matemática. Finalizando essa explanação, o professor comenta: 
"O importante aqui nessa aula é que vocês entendam bem como é

que eu tiro informação do gráfico, como é que essa representação no movimento que nós estamos vendo permite que a gente interprete bem e entenda o que está acontecendo". Ep. VI

No episódio IV, sobre a resolução de problemas de lançamentos, o professor exemplifica:

"Se delta for negativo temos que interpretar. Tem i (número imaginário), mas não tem significado físico. Esse tipo de análise ou interpretação em vários problemas de lançamento de projéteis vocês vão ter que fazer". Ep. IV

Esse exemplo exalta a diferença entre a interpretação matemática e a interpretação física. Matematicamente, um delta negativo em uma equação de segundo grau significa que a equação não tem solução no conjunto dos números reais, mas tem solução no conjunto dos números complexos. Fisicamente, no contexto da aula (exercícios de lançamentos de projéteis), esse resultado não tem sentido físico.

No estudo de caso, o professor explana também como é possível interpretar diferentes equações (ou sistemas de coordenadas) que representam um mesmo movimento:

\footnotetext{
"Se eu passo pro sistema de coordenadas polares a interpretacão é mais fácil" Ep. IV
}

"Eu tenho mais trabalho com a conta (coordenadas polares), mas interpreto mais fácil o resultado da conta. Eu tenho mais segurança, menos problema pra fazer conta no sistema cartesiano, mas vou pagar o preço que é ter mais trabalho para interpretar a resposta". Ep. IV

O professor orienta explicitamente os alunos a efetuar operações matemáticas (mudança de coordenadas) para facilitar a interpretação física de um movimento.

Em outro episódio, o mesmo professor esclarece que na física o fazer conta (caráter instrumental da matemática na física) nem sempre vai ser o "problema" a 
ser selecionado, e sim, entender o que a conta, a fórmula ou o resultado numérico significa:

“(...) E a medida que vocês forem ganhando intimidade, digamos assim, com o cálculo diferencial e integral, passando a derivar etc. fazer a conta não vai ser o problema, o problema vai ser mesmo interpretar a resposta, porque aí você tem uma expressão desse tamanho e a gente não consegue entender o que ela diz. Se você consegue transformar uma equação desse tamanho em uma coisa mais compacta aonde o significado dela salta aos olhos é mais fácil a gente perceber o que está acontecendo". Ep. V

A ideia de um significado "saltando aos olhos" é uma metáfora às notações e representações comumente utilizadas na física (por exemplo, um sinal negativo na velocidade indica que o móvel está em um movimento contrário ao referencial adotado). Ao estudar física, ao "viver a física" o estudante se "apodera" dos símbolos, signos e significados que algumas representações possuem e ao encontrá-los, quase que instantaneamente e "instintivamente" ele os compreende, interpreta.

A ideia de que uma equação ou expressão matemática adquire significado através da interpretação física também é uma relação entre a física e a matemática que foi citada em alguns episódios.

Por exemplo, no episódio VII, no questionamento da significação da área positiva e negativa de um gráfico, tem-se mais um exemplo das distintas atuações da física com a matemática: elas se relacionam e se interpolam, mas possuem papéis distintos na interpretação do que uma fornece à outra.

"O que significa área positiva e área negativa? Fisicamente, a área positiva significa que o deslocamento do móvel foi positivo, ou seja, o móvel está se movendo a favor do eixo. Já a área negativa significa que o deslocamento foi no sentido oposto à orientação do eixo $x$. Matematicamente, essa significação não existe, o sentido é puramente físico." Ep. VII

No episódio IV, resolvendo a equação de segundo grau encontrou-se dois resultados numéricos, um positivo e outro negativo: 
"Esse número negativo não faz sentido físico no contexto do problema. O que significa um tempo negativo? (...) Não faz sentido aquela resposta negativa e a gente tem que perceber isso, analisar e ver se faz ou não sentido a resposta dependendo do enunciado". Ep. IV

As soluções matemáticas são números, isentos de significação. Ao inserir essa mesma equação em um problema físico, essas soluções devem ser pensadas e questionadas, pois elas passam a "carregar" significados. Novamente, nesse episódio de ensino, a inserção da significação faz a física extrapolar a matemática na Mecânica.

No episódio V, o professor questiona:

"O que significa fisicamente o sinal negativo? Como sei matematicamente que está para dentro?" Ep. V

O sinal negativo (matemático) tem um significado físico no contexto do problema. Assim como, no episódio III, a questão dimensional (matemática) está intimamente ligada a questão física:

"O que significa dizer que um movimento é plano? É um movimento bidimensional." Ep. III

Ao interpretar um vetor velocidade que só possui o versor i, o professor comenta:

"O que significa isso? Que nesse intervalo velocidade em y é nula, só tem velocidade em $x "$. Ep. IX

Os versores possuem um significado físico que permite a interpretação do movimento através desse significado. A interpretação está intrinsicamente relacionada à significação, estabelecendo uma relação mútua que envolve a matemática e os conceitos físicos.

Em alguns episódios, a ideia de que é necessário efetuar uma abstração dos números, resultados etc., para entender o conhecimento físico fica explícita.

No episódio I, por exemplo, é retratado como uma expressão matemática, oriunda de uma abstração, representa um conceito físico na mecânica. Quando se diz "O conceito de velocidade instantânea é uma abstração matemática" a 
significação física está presente através da equação matemática, e é possível observar a intrínseca relação entre a física e a matemática na construção desse conceito.

"Esse procedimento que descrevi com palavras precisamos expressar matematicamente. O conceito de velocidade instantânea é uma abstração matemática". Ep. 1

No episódio V, o professor comenta que é necessário treinar a abstração e interpretação das informações que os números transmitem em um problema físico, já que o ato de resolver a conta, sem refletir e sem questionar, não é o objetivo da física:

"O nosso objetivo não é simplesmente escrever alguma coisa e sair fazendo conta, eu quero perceber qual é o movimento. Eu quero saber se o movimento é circular, eu quero saber se o movimento é uniforme, helicoidal, eu quero saber se o movimento é uma elipse etc. eu quero entender o movimento que está sendo descrito por um conjunto de equações, fazer uma visão na minha cabeça - se isso for possível - e se não for possível imaginar, porque pode ser uma curva complicada que a gente não consegue abstrair, imaginar, pelo menos matematicamente extrair informacões que me permitam perceber qual é a direção do movimento, a velocidade ... é isso que a gente quer treinar (...)" Ep. V

A fala do professor corrobora com a ideia que a abstração é um processo importante no estudo da física, pois precisamos extrair de equações, símbolos e resultados numéricos um sentido físico nos problemas.

A física busca representar a realidade e utiliza a matemática nessa busca. Não é possível descrever com total realismo o mundo com frases e equações, ao utilizarmos os formalismos matemáticos, por exemplo, já estamos fazendo "recortes" da realidade. Por isso, já estamos utilizando representações de formas abstratas, sendo necessário pensar e abstrair as informações que elas nos fornecem, muitas vezes interpretando e atribuindo significados a essas formas. Por isso, é importante ressaltar que nesse caso apresentado não é possível delimitar as fronteiras entre a interpretação, a significação e a abstração. Apesar de ter observado nesse capítulo o caráter interpretativo, significativo e abstrato que a relação da física com a 
matemática fornece separadamente, esses três pontos destacados no estudo de caso não são excludentes, ao contrário, são pontos complementares e interdependentes: dar um significado para um resultado numérico transita pela interpretação desse resultado e pela abstração que esse resultado permite exprimir. Eles se fundem, interagem, eles pertencem ao instrumento de pensamento que permite estruturar a física.

\subsection{A linguagem matemática e a estruturação da física}

No nosso estudo de caso foi possível identificar referências explícitas dos professores a respeito do uso da linguagem (verbal e matemática) na física:

"O que eu quero chamar a atenção é que tem que parar pra pensar o que cada problema está dizendo. A formulação é sempre a mesma, são essas situações básicas. Eu posso dar a velocidade, eu posso dar a posição ...E eu vou ter que combinar essas equações com as funções físicas que estão sendo indicadas no enunciado pra compreender o que está sendo perguntado e o que eu conheço e ver como eu vou lidar com isso. Lembrando sempre que a gente tem que traduzir essas perguntas do português do enunciado em condições matemáticas para conseguir resolver o problema". Ep. IV

No episódio IV, o professor fala em traduzir uma língua, que é a portuguesa, para outra forma de transmitir uma mensagem, que é a matemática, encarando-a como linguagem, já que é passível de tradução. Uma das relações entre a física e a matemática levantadas anteriormente nos referenciais é a de que a matemática muitas vezes desempenha o papel de linguagem da física, transmitindo a mensagem que a ciência não consegue exprimir com palavras. Nesse episódio, essa relação é ressaltada.

No episódio I é possível identificar duas referências que relacionam as palavras à matemática:

"A equação (eq.1) é a forma matemática de expressar o que expressamos em palavras" Ep. 1 
"Esse procedimento que descrevi com palavras precisamos expressar matematicamente. $\mathrm{O}$ conceito de velocidade instantânea é uma abstração matemática". Ep. 1

A transição palavras - matemática - física é simbiótica, ou seja, nas palavras é preciso extrair informações matemáticas e físicas, e vice-versa. No episódio VI o professor explana:

"No fundo é sempre a mesma coisa, quando um problema propõe uma situação a gente tem que parar pra pensar o que que traduz aquela situação do ponto de vista matemático e físico. Que propriedade está por trás daquela perqunta". Ep. VI

Esse exemplo verbaliza que o estudante precisa sempre parar para pensar as ideias físicas e suas representações matemáticas, ou seja, precisa exercer continuamente no seu aprendizado a reflexão.

Nos episódios de ensino, em alguns momentos os professores dialogaram com os alunos a respeito da física e do fazer física, ultrapassando a especificidade da disciplina Fundamentos de Mecânica e levantando apontamentos que os alunos escutarão e se depararão por todo o curso de física.

Ao refletir sobre os problemas estudados na aula, o professor, no episódio III, explicita um dos objetivos da física:

"O objetivo máximo da física é entender a realidade". Ep. III

Esse exemplo configura e justifica o "como" é possível entender a realidade na física. Quais são os artifícios que ela usa? Como a física representa essa realidade além da conceitualização? Um dos artifícios é através da matemática e seus papéis na ciência.

Sabemos que no ensino de física, saber usar uma fórmula para resolver problemas quantitativos e demonstrar uma fórmula a partir de princípios físicos são processos diferentes, porém igualmente importantes. O caráter técnico do uso da matemática no ensino de física não exclui o caráter relacional, e vice-versa. Acreditamos que esses dois caráteres que usamos como norte na análise do estudo de caso são complementares e permitem pensar na matemática como uma linguagem que proporciona a estruturação da física. 
Nos episódios de ensino destacamos anteriormente alguns exemplos do caráter instrumental (representações matemáticas, exercícios de aplicação etc.) e alguns aspectos do caráter relacional (interpretação, significação e abstração matemática) da matemática no ensino e aprendizagem de física. Essas observações permitiram a criação de uma esquematização (Imagem III) que resume a complexa interação entre todos esses aspectos:

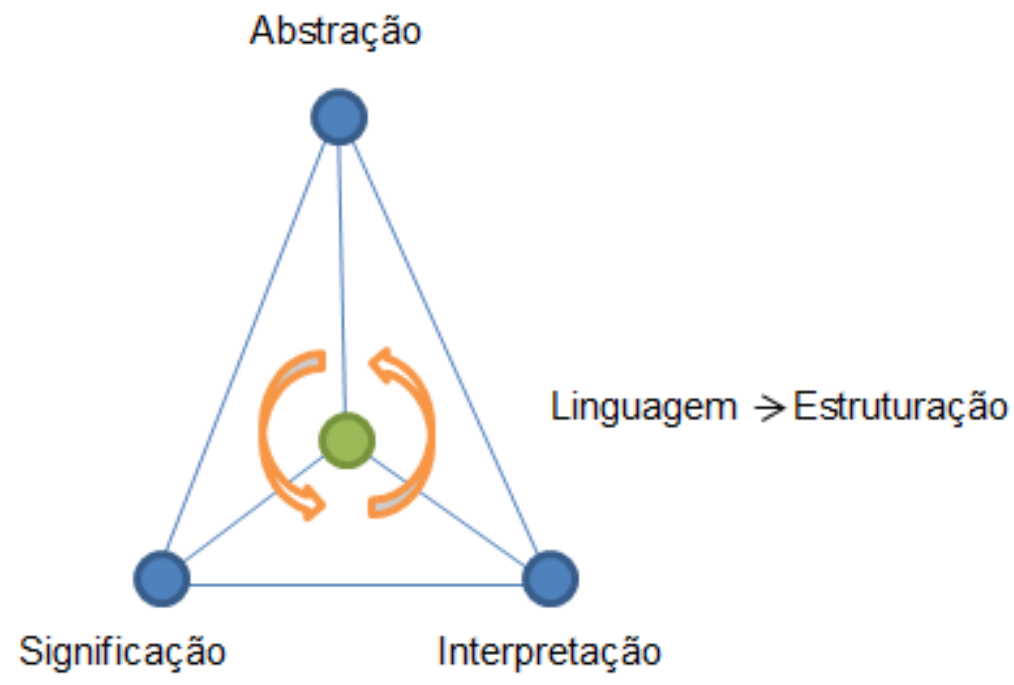

Imagem III: Proposta de esquema sintético da estruturação matemática da física

No esquema, as flechas centrais que rotacionam em sentido anti-horário representam o caráter técnico/instrumental/procedimental do uso da matemática na física. Esse caráter é cíclico porque, por exemplo, a manipulação de algoritmos de cálculo segue uma sequência que em alguns problemas pode ser repetida ciclicamente para a obtenção de uma resposta numérica. Outro exemplo nesse caso é a repetição de exercícios padrões. Os aspectos interpretação, significação e abstração formam um tripé que solidifica o esquema, já que permitem a interação do caráter técnico com o caráter relacional. Acreditamos que essa interação, quando ocorre, proporciona a construção de uma linguagem entre a física e a matemática, associando-as em uma simbiose e permitindo uma estruturação da física. 


\section{Considerações finais}

\section{Considerações finais}

Quando buscamos a definição da palavra "Plural" ou sua derivada "Pluralidade" no dicionário encontramos (MICHAELIS, 2014):

Diz-se do número que designa mais de um ser. Exprime a existência de mais de um ser ou da ação feita por mais de um ser.

Resumidamente, podemos pensar na palavra plural como "mais de um". Ao falar do papel da matemática na física é possível afirmar que não existe somente um tipo de relação estabelecida entre elas: essas relações são múltiplas e podem ser observadas em diversas situações.

No nosso estudo de caso observamos primeiramente a apresentação dos conteúdos de fundamentos de mecânica com enfoques diferentes em duas turmas distintas com dois docentes. É possível afirmar através da amostra apresentada que apesar de as turmas pertencerem a uma mesma disciplina os cursos parecem diferentes.

Nesse estudo de caso, o professor da Turma A tinha como característica ser o professor "central", ou seja, suas aulas eram focadas nas suas explicações na lousa e explanações, sem a participação efetiva dos alunos. Essas explicações muitas vezes priorizavam a reflexão sobre os conceitos ensinados. Já na Turma B o professor não era central, pois nas aulas sempre havia trocas entre o professor e os alunos, além da resolução de exercícios propostos durante as aulas e em grupos.

Outra observação importante se refere a duas ações que são comumente presentes no ensino de física e que foram abordadas com enfoques diferentes nas duas turmas: o saber fazer (por exemplo, saber construir um gráfico espaço por tempo) e o saber compreender o que foi feito (interpretar e dar significado a esse gráfico, por exemplo). O docente da turma B claramente se dedicou mais a ensinar o fazer, o "mão na massa". Nas aulas, era comum uma explicação do passo a passo para construir uma escala, colocar as legendas, resolver uma equação etc. Já o docente da Turma A enfatizou o saber compreender o que foi feito (não 
necessariamente pelos alunos, e sim na lousa ou livro). Essa diferença de enfoques permite compreender a grande diferença entre as aulas ministradas (desde a dinâmica até as formalizações matemáticas).

Podemos afirmar que as aulas do professor da Turma A trouxeram mais elementos que contribuíram para a pesquisa e que isso não significa que essas aulas são melhores e que os alunos dessa turma aprenderam mais que os alunos que cursaram as aulas ministradas na Turma B, já que as duas turmas são distintas e com históricos diferentes. Não conhecemos na literatura trabalhos que permitam afirmar qual metodologia é a melhor no início do curso de licenciatura em física, mas acreditamos que esses dois aspectos (o saber fazer e o saber compreender o que foi feito) são importantes no ensino.

$\mathrm{Na}$ minha experiência pessoal, como aluna eu cursei a disciplina Fundamentos de Mecânica com outro docente e o curso foi diferente do apresentado nesse estudo de caso. Sei que, como aluna e na época em que iniciei minha licenciatura, teria mais facilidade em me ambientar e compreender as aulas da Turma $B$ devido à similaridade com o formato das aulas do ensino médio que ela possuía. No entanto, como pesquisadora e com o conhecimento físico mais consolidado, as aulas da Turma A permitiram novos aprendizados e reflexões que eu não havia construído quando cursei a disciplina.

É importante ressaltar que ao escolher como estudo de caso o curso de Fundamentos de Mecânica, que tinha duas turmas e docentes diferentes, não eram conhecidas a priori as características de cada turma e as metodologias das aulas. É possível afirmar que essa pesquisa ganhou esse perfil em função das características distintas encontradas nas aulas dos dois docentes, e que, se fosse realizado o mesmo procedimento metodológico de pesquisa com outras turmas e docentes a pesquisa poderia trazer outros elementos que não estiveram presentes nesse trabalho. Por isso a palavra plural se encaixa muito bem no título desse trabalho, pois tivemos a oportunidade de vivenciar visões e explanações diferentes e múltiplas de uma mesma disciplina. 
Como vimos, na área de ensino de física existem trabalhos que discutem a relação da física com a matemática sobre diversas óticas (às vezes distintas, às vezes complementares). Nos principais eventos de ensino de física da última década podemos destacar que essas pesquisas estão prioritariamente discutindo o tema no ensino médio e ensino fundamental. Existem também trabalhos que observam no curso superior, e a pesquisa aqui apresentada se enquadra nessa classificação.

Nas pesquisas já realizadas nessa temática, foi possível identificar que uma das facetas da matemática na física é seu caráter técnico e instrumental. Muitos pesquisadores criticam o que chamam de "matematização" no ensino, que seria a resolução sistemática e repetitiva de problemas e exercícios na física sem existir uma discussão sobre esses problemas.

É indiscutível que não foi possível e não é possível fazer e estudar física totalmente sem a matemática. As deduções, equações e teorias são fundamentais para cercear alguns conceitos físicos. Também sabemos que pensar a física somente com a matemática é uma visão generalista.

Transpassando o caráter técnico da atuação da matemática na física, PIETROCOLA (2002) traz a ideia que a matemática, através da linguagem matemática, é estruturante do conhecimento físico, e por isso, é necessário discutir quais aspectos favorecem a visualização da construção dessa ideia nos estudantes, seja no ensino médio ou ensino superior.

Por isso, nesse trabalho olhamos também para "momentos" que o caráter operacional ficou evidente no estudo de caso e "momentos" que o caráter relacional foi explicitado.

No caráter operacional da matemática nas aulas de Fundamentos de Mecânica em duas turmas diferentes, focamos nossa análise nas representações matemáticas utilizadas, a transitividade das notações matemáticas, o aspectos operacional (técnico) e a presença de conteúdos do curso de cálculo e geometria analítica nas aulas de Fundamentos de Mecânica. 
No caráter relacional, conseguimos identificar nos episódios de ensino alguns aspectos que extrapolam essa relação técnica e alcançam uma relação organizacional. Esses aspectos citados pelos docentes foram a Interpretação, Significação e Abstração. A respeito da significação, LOZADA (2008) afirma:

É importante deixar claro desde cedo aos alunos que os modelos matemáticos desenvolvidos no Ensino de Física possuem um sentido agregado ao fenômeno em estudo, que suas variáveis possuem um significado, não constituindo um conjunto de símbolos vazios. LOZADA (2008: 2)

O autor destaca o "deixar claro", ou seja, incitar explicitamente os alunos a pensarem sobre o significado das representações matemáticas, que representa um passo a mais em relação somente à resolução de um problema com entidades matemáticas. Podemos perceber nesse estudo de caso que o docente da turma $A$ realizou essa ação (explicitação verbal) com bastante frequência e que o docente da Turma B o fez em poucos momentos de sua aula.

Com essa análise conseguimos teorizar que esses três aspectos levantados (Interpretação, Significação e Abstração), juntamente com o caráter técnico/instrumental do uso da matemática no ensino e aprendizagem da física estão interligados, favorecendo a utilização da linguagem matemática nas aulas de física que permite uma estruturação do pensamento físico.

A respeito da linguagem matemática, CARMO (2006) exemplifica com uma ação em sala de aula:

No caso da linguagem matemática, deve-se explicitar quais recursos pertencem à mesma. Por exemplo, ao trabalhar um gráfico o professor deve deixar claro os recursos tipológicos e topológicos dessa linguagem. Dentre os recursos tipológicos temos, por exemplo, as variáveis como energia, tempo e temperatura. Já os recursos topológicos são os valores das variáveis, a forma da curva com suas inclinações e a organização visual que o gráfico proporciona. CARMO (2006: 3) 
Mais um autor, em sua fala, afirma a necessidade de explicitação da linguagem matemática utilizada em determinado contexto no ensino de física.

Como foi discutida anteriormente, a estruturação do pensamento através da linguagem matemática é uma habilidade importante na aprendizagem da Ciência. $A$ respeito disso, $\quad$ PIETROCOLA (2002) sintetiza:

Se a matemática é a linguagem que permite ao cientista estruturar o seu pensamento para aprender o mundo, o ensino de Ciências deve propiciar meios para que os estudantes adquiram esta habilidade. [...] Assim, um dos atributos essenciais ao educador com relação a esta questão é perceber que não se trata apenas de saber Matemática para poder operar as teorias Físicas que representam a realidade, mas de saber apreender teoricamente o real através de uma estruturação matemática. PIETROCOLA (2002: 110)

O autor cita que é necessário extrapolar a ideia que muitos professores têm que a matemática somente faz parte de um sistema operacional da física e partir para a construção da ideia que a matemática é uma linguagem que permite a estruturação da física.

O que podemos afirmar com esse estudo exemplificador, é que as relações explanadas nesse trabalho não são exclusivas, pelo contrário, o caráter técnico e o caráter relacional fundem-se proporcionando inúmeras reflexões a respeito de suas interações.

O estudo de caso realizado nessa pesquisa serve como um dado exemplificador de como as relações da física com a matemática podem aparecer em um curso introdutório na licenciatura em física. Não podemos generalizar e tomar o estudo aqui apresentado como um padrão, pois utilizamos uma amostra com o intuito de exemplificar reflexões levantadas também por outros pesquisadores.

Essa pesquisa tem também como intenção levantar outros questionamentos que o estudo de caso apresentado não abarca mais que são de suma importância para a temática apresentada. 
Um desses questionamentos está relacionado à percepção dos alunos a respeito da relação da física com a matemática. É possível delinear quando isso acontece e porquê? Quais atividades estimulam essa reflexão? O aluno precisa ouvir ou ser questionado explicitamente sobre o assunto ou essa percepção é íntima? Quando os colegas professores e pesquisadores pensaram ou sentiram pela primeira vez essa questão?

Outro questionamento se refere à adequação das grades curriculares das licenciaturas em física no Brasil. Quais as consequências, benefícios e malefícios do fato de que as primeiras disciplinas da licenciatura em física são cursadas concomitantemente com as disciplinas introdutórias da matemática (cálculo, geometria analítica, por exemplo)? É vantajoso que o professor de física explique aspectos técnicos do cálculo em suas aulas para contribuir no entendimento do aluno? Quais são as implicações disso?

Essa temática permite muitos questionamentos e inquietações. Essa dissertação buscou trazer elementos exemplificadores de alguns aspectos que já podem ser sentidos no início da formação de um professor de física e por isso já levantam outras demandas para as futuras pesquisas na área. 


\section{Referências Bibliográficas}

\section{Referências Bibliográficas}

ANJOS, A.; CABALLERO, C.; MOREIRA, M. As equações matemáticas no ensino de física: uma análise da exposição didática dos conteúdos nos livros textos de física. In: ENCONTRO DE PESQUISA EM ENSINO DE FÍSICA (EPEF), 12, 2010, Águas de Lindoia, SP. Trabalhos do XII Encontro de Pesquisa em Ensino de Física. São Paulo: Sociedade Brasileira de Física. Disponível em: < http://www.sbfisica.org.br/ epef/xii/indexc655.html?option=com_wrapper\&view=wrap per\&ltemid=15>. Data de acesso: 20/mar/2012.

ANJOS, A.; CABALLERO, C.; MOREIRA, M. As equações matemáticas no ensino de física: o que pensam os professores. In: ENCONTRO DE PESQUISA EM ENSINO DE FÍSICA (EPEF), 13, 2011, Foz do Iguaçu, PR. Trabalhos do XIII Encontro de Pesquisa em Ensino de Física. São Paulo: Sociedade Brasileira de Física. Disponível em: <http://sbfisica.org.br/ fisica2011/index22cb.html?option=com_wrapper\&view=wrapp er\&ltemid=13>. Data de acesso: 20/mar/2012.

ALMEIDA, M. J. P. M. - Linguagens Comum e Matemática em Funcionamento no Ensino de Física. II Encontro Nacional de Pesquisa em Educação em Ciências, 1999.

ALMEIDA, M. A relevância das linguagens matemática e comum na produção e ensino da física. In: SIMPÓSIO NACIONAL DE ENSINO DE FÍSICA (SNEF), 20, 2013, São Paulo, SP. Trabalhos do XIX Simpósio Nacional de Ensino de Física. Disponível em: <http://www.sbf1.sbfisica.org.br/eventos/snef/xx/atas/trabalhos.htm>. Data de acesso: 10/jun/2014.

ATAÍDE, A.; GRECA, I. Relações entre conhecimento conceitual, domínio de técnicas matemáticas e visões do papel da Matemática na Física e na resolução de problemas sobre a Primeira Lei da Termodinâmica. In: ENCONTRO DE PESQUISA EM ENSINO DE FÍSICA (EPEF), 12, 2010, Águas de Lindoia, SP. Trabalhos do XII Encontro de Pesquisa em Ensino de Física. São Paulo: Sociedade Brasileira de Física. Disponível em: $<$ http://www.sbfisica.org.br/ epef/xii/indexc655.html?option=com_wrapper\&view=wrap per\&ltemid=15>. Data de acesso: 20/mar/2012.

BACHELARD. G., "A experiência do espaço na física contemporânea", 1a ed., Rio de Janeiro, Contraponto, 2010.

CAMPOS, L.S. "Articulação entre modelagem matemática e experimentação: uma proposta para a construção de conhecimento em física". Mestrado profissional. 
UNIVERSIDADE CRUZEIRO DO SUL - ENSINO DE CIÊNCIAS E MATEMÁTICA, 2010.

CAMPOS, L.; ARAÚJO, M. A Modelagem Matemática aplicada no Estudo Experimental de Fenômenos Físicos: uma Possibilidade para o Ensino de Física. In: ENCONTRO DE PESQUISA EM ENSINO DE FÍSICA (EPEF), 13, 2011, Foz do Iguaçu, PR. Trabalhos do XIII Encontro de Pesquisa em Ensino de Física. São Paulo: Sociedade Brasileira de Física. Disponível em: <http://sbfisica.org.br/ fisica2011/index22cb.html?option=com_wrapper\&view=wrapp er\&ltemid=13>. Data de acesso: 20/mar/2012.

CAMPOS, L.; ATAÚJO, M. A modelagem matemática e a experimentação utilizadas como recursos para a construção do conhecimento em física. In: SIMPÓsIO NACIONAL DE ENSINO DE FÍSICA (SNEF), 19, 2011, Manaus, AM. Programação do XIX Simpósio Nacional de Ensino de Física. Disponível em: <http://www.sbfisica.org.br/ snef/xix/index.php?option=com_wrapper\&view=wrapper \&ltemid=16>. Data de acesso: 20/mar/2012.

CAMARGO FILHO, P.; LABURÚ, C. Dificuldades semióticas na construção de gráficos cartesianos de cinemática. In: ENCONTRO DE PESQUISA EM ENSINO DE FíSICA (EPEF), 12, 2010, Águas de Lindóia, SP. Trabalhos do XII Encontro de Pesquisa em Ensino de Física. São Paulo: Sociedade Brasileira de Física. Disponível em:

http://www.sbfisica.org.br/ epef/xii/indexc655.html?option=com_wrapper\&view=wrap per\&ltemid=15>. Data de acesso: 20/mar/2012.

CARDOSO, D.; GURGEL, I. A complementaridade das linguagens narrativas e matemática no contexto da gestação da relatividade geral. In: SIMPÓSIO NACIONAL DE ENSINO DE FÍSICA (SNEF), 20, 2013, São Paulo, SP. Trabalhos do XIX Simpósio Nacional de Ensino de Física. Disponível em: <http://www.sbf1.sbfisica.org.br/eventos/snef/xx/atas/trabalhos.htm>. Data de acesso: 10/jun/2014.

CARMO, A.; CARVALHO, A.M. Iniciando os estudantes na matemática da física através de aulas experimentais investigativas. In: ENCONTRO DE PESQUISA EM ENSINO DE FÍSICA (EPEF), 10, 2006, Londrina, PR. Atas do X Encontro de Pesquisa em Ensino de Física. São Paulo: Sociedade Brasileira de Física, 2007. 1CD-ROM.

CARMO, A.B. "A linguagem matemática em uma aula experimental de Física." Dissertação de mestrado. UNIVERSIDADE DE SÃO PAULO - ENSINO DE CIÊNCIAS (MODALIDADES FÍSICA, QUÍMICA E BIOLOGIA), 2006.

CORRÊA, S.; et al. Proposta didática e procedimentos para a superação de dificuldades matemáticas para introdução da física no ensino fundamental. In: SIMPÓSIO NACIONAL DE ENSINO DE FÍSICA (SNEF), 20, 2013, São Paulo, SP. 
Trabalhos do XIX Simpósio Nacional de Ensino de Física. Disponível em: <http://www.sbf1.sbfisica.org.br/eventos/snef/xx/atas/trabalhos.htm>. Data de acesso: 10/jun/2014.

ELONEID, F.; MORETZSOHN, R.; DIEB, V.; CINTRA, A. Introdução ao ensino da física: uma abordagem fenomenológica ou matemática?. In: SIMPÓSIO NACIONAL DE ENSINO DE FÍSICA (SNEF), 15, 2003, Curitiba. Atas do XV Simpósio Nacional de Ensino de Física. Curitiba: CEFET-PR, 2003. p. 904-909. 1 CD-ROM.

FEITOSA, L. Os licenciandos em física e as relações que os levaram a cursar a licenciatura em física: a matemática e a física escolar. In: SIMPÓSIO NACIONAL DE ENSINO DE FÍSICA (SNEF), 20, 2013, São Paulo, SP. Trabalhos do XIX Simpósio Nacional de Ensino de Física. Disponível em: $<$ http://www.sbf1.sbfisica.org.br/eventos/snef/xx/atas/trabalhos.htm>. Data de acesso: 10/jun/2014.

FEYNMAN, R. P.; O que é uma Lei Física? Gradiva, Lisboa, 2000.

GALILEI, Galileu. O ensaiador - Coleção Os pensadores.. São Paulo: Abril Cultural, 1973.

GURGEL, I.; PIETROCOLA, M. Papel do pensamento narrativo e do pensamento lógico-matemático no desenvolvimento científico: uma análise epistemológica através do inicio da eletrodinâmica. In: ENCONTRO DE PESQUISA EM ENSINO DE FíSICA (EPEF), 13, 2011, Foz do Iguaçu, PR. Trabalhos do XIII Encontro de Pesquisa em Ensino de Física. São Paulo: Sociedade Brasileira de Física. Disponível em: <http://sbfisica.org.br/ fisica2011/index22cb.html?option=com_wrapper\&view=wrapp er\&ltemid=13>. Data de acesso: 20/mar/2012.

HAMMES, O. "O ensino das funções e do movimento de queda livre dos corpos: uma proposta para as disciplinas de matemática e ciências.". Mestrado profissional. UNIVERSIDADE REGIONAL DE BLUMENAU - Ensino de Ciências Naturais e Matemática, 2010.

JULIO, J.; VAZ, J. BORGES, A. Construção de gráficos em atividade de investigação: microanálise de uma aula de Física. In: ENCONTRO DE PESQUISA EM ENSINO DE FÍSICA (EPEF), 11, 2008, Curitiba, PR. Atas do XI Encontro de Pesquisa em Ensino de Física. São Paulo: Sociedade Brasileira de Física, 2010. Disponível em: <http://www.sbf1.sbfisica.org.br/eventos/epef/xi/atas/trabalhos.htm>. Data de acesso: 20/mar/2012.

JUSTINIANO, G. et al. Análise do tratamento matemático do movimento em livros didático segundo olhares de aprendizagem, curriculares e epistemológicos. In: SIMPÓSIO NACIONAL DE ENSINO DE FÍSICA (SNEF), 20, 2013, São Paulo, SP. Trabalhos do XIX Simpósio Nacional de Ensino de Física. Disponível em: < 
http://www.sbf1.sbfisica.org.br/eventos/snef/xx/atas/trabalhos.htm>. Data de acesso: 10/jun/2014.

KARAM, R. A. S. ; PIETROCOLA, M. . Habilidades Técnicas Versus Habilidades Estruturantes: Resolução de Problemas e o Papel da Matemática como Estruturante do Pensamento Físico. Alexandria - Revista de Educação em Ciência e Tecnologia, v. 2, p. 181/2-205, 2009.

KARAM, R.; PIETROCOLA, M. Resolução de problemas e o papel da matemática como estruturante do pensamento físico. In: SIMPÓSIO NACIONAL DE ENSINO DE FíSICA (SNEF), 18, 2009, Vitória, ES. Anais do XVIII Simpósio Nacional de Ensino de Física. Disponível em: <http://www.sbf1.sbfisica.org.br/eventos/snef/xviii/>. Data de acesso: 20/mar/2012.

KARAM, R.; PIETROCOLA, M. Formalização matemática x física moderna no ensino médio: é possível solucionar esse impasse?. In: ENCONTRO DE PESQUISA EM ENSINO DE FÍSICA (EPEF), 11, 2008, Curitiba, PR. Atas do XI Encontro de Pesquisa em Ensino de Física. São Paulo: Sociedade Brasileira de Física, 2010. Disponível em: <http://www.sbf1.sbfisica.org.br/eventos/epef/xi/atas/trabalhos.htm>. Data de acesso: 20/mar/2012.

KARAM, R.; POSPIECH, G.; PIETROCOLA, M. Abordagem do caráter estruturante da matemática em aulas de eletromagnetismo. In: ENCONTRO DE PESQUISA EM ENSINO DE FÍSICA (EPEF), 13, 2011, Foz do Iguaçu, PR. Trabalhos do XIII Encontro de Pesquisa em Ensino de Física. São Paulo: Sociedade Brasileira de Física.

$<$ http://sbfisica.org.br/ fisica2011/index22cb.html?option=com_wrapper\&view=wrapp er\&ltemid=13>. Data de acesso: 20/mar/2012.

KARAM, R.A.S. "Estruturação matemática do pensamento físico no ensino: uma ferramenta teórica para analisar abordagens didáticas." Tese de doutorado. São Paulo: s.n., 2012.

KRAPAS, S. Modelos, matemática e física na história da ciência e no ensino: os casos da luz como onda e como onda eletromagnética. In: ENCONTRO DE PESQUISA EM ENSINO DE FÍSICA (EPEF), 13, 2011, Foz do Iguaçu, PR. Trabalhos do XIII Encontro de Pesquisa em Ensino de Física. São Paulo: Sociedade Brasileira de Física. Disponível em: <http://sbfisica.org.br/ fisica2011/index22cb.html?option=com_wrapper\&view=wrapp er\&ltemid=13>. Data de acesso: 20/mar/2012.

LOCATELLI, R.; CARVALHO, A. M. Os raciocínios hipotéticos - dedutivos e proporcionais nas aulas de ciência. In: ENCONTRO DE PESQUISA EM ENSINO DE FíSICA (EPEF), 09, 2004, Jaboticatubas. Atas do IX Encontro de Pesquisa em Ensino de Física. Jaboticatubas: MG: Sociedade Brasileira de Física, 2004. 1CDROM. 
LOCATELLI, R.; CARVALHO, A.M. Os raciocínios hipotéticos - dedutivos e proporcionais nas aulas de ciência. In: SIMPÓSIO NACIONAL DE ENSINO DE FíSICA (SNEF), 16, 2005, Rio de Janeiro. Anais do XVI Simpósio Nacional de Ensino de Física. Disponível em:< http://www.sbf1.sbfisica.org.br/eventos/snef/xvi/cd/>. Data de acesso: 20/mar/2012.

LOPES, J.P. "Fragamentações e aproximações entre matemática e física no contexto escolar: problematizando o conceito de função AFIM." Dissertação de Mestrado. UNIVERSIDADE FEDERAL DE SANTA CATARINA - EDUCAÇÃO CIENTIFICA E TECNOLÓGICA, 2004.

LOZADA, C.; MAGALHÃES, N. A importância da modelagem matemática na formação de professores de física. In: SIMPÓSIO NACIONAL DE ENSINO DE FísICA (SNEF), 18, 2009, Vitória, ES. Anais do XVIII Simpósio Nacional de Ensino de Física. Disponível em: <http://www.sbf1.sbfisica.org.br/eventos/snef/xviii/>. Data de acesso: 20/mar/2012.

LOZADA, C.; MAGALHÃES, N. Um estudo de caso relacionando formação de professores, modelagem matemática e resolução de problemas no ensino de física. 2008 In: ENCONTRO DE PESQUISA EM ENSINO DE FÍSICA (EPEF), 11, 2008, Curitiba, PR. Atas do XI Encontro de Pesquisa em Ensino de Física. São Paulo: Sociedade Brasileira de Física, 2010. Disponível em: <http://www.sbf1.sbfisica.org.br/eventos/epef/xi/atas/trabalhos.htm>. Data de acesso: 20/mar/2012.

LOZADA, C.; MAGALHÃES, N. Um estudo de caso sobre a formação de professores de física e a prática da modelagem matemática aplicada ao ensino de física. In: SIMPÓSIO NACIONAL DE ENSINO DE FÍSICA (SNEF), 19, 2011, Manaus, AM. Programação do XIX Simpósio Nacional de Ensino de Física. Disponível em: $<$ http://www.sbfisica.org.br/ snef/xix/index.php?option=com_wrapper\&view=wrapper \&ltemid=16>. Data de acesso: 20/mar/2012.

LÜDKE, M.; ANDRÉ, M.E.D. Pesquisa em Educação: Abordagens Qualitativas. São Paulo: EPU, 1986.

MARTINI, M. G. A. O conhecimento físico e sua relação com a matemática: um olhar voltado para o ensino médio - Dissertação de mestrado - São Paulo -2006.

MICHAELIS. Moderno Dicionário da Língua Portuguesa. Disponível em: $<$ http://michaelis.uol.com.br/moderno/portugues/index.php>. Acesso em: 25 setembro. 2014.

MORRONE, W.; LOZADA, C.; AMARAL,L.; ARAÚJO, M. Modelagem matemática e a atividade experimental como um modelo de integração no ensino de física. 2007. In: SIMPÓSIO NACIONAL DE ENSINO DE FÍSICA (SNEF), 17, 2007, São Luis, MA. Anais do XVII Simpósio Nacional de Ensino de Física. Disponível em: 
$<$ http://www.sbf1.sbfisica.org.br/eventos/snef/xvii/atas/trabalhos.htm>. acesso: 20/mar/2012.

PAULINO, A.; PAULINO, I.; FELIX, P. A falta de conhecimento de matemática atrapalha o aprendizado de física de alunos de ensino médio?. In: SIMPÓSIO NACIONAL DE ENSINO DE FÍSICA (SNEF), 17, 2007, São Luis, MA. Anais do XVIi

Simpósio Nacional de Ensino de Física. Disponível em: < http://www.sbf1.sbfisica.org.br/eventos/snef/xvii/atas/trabalhos.htm>. Data de acesso: 20/mar/2012.

PATY, Michel. A matéria roubada, 1995, EDUSP, SP.

PEREIRA, L. Contribuições do cálculo à aprendizagem da hidrostática. In: SIMPÓSIO NACIONAL DE ENSINO DE FÍSICA (SNEF), 16, 2005, Rio de Janeiro. Anais do XVI Simpósio Nacional de Ensino de Física. Disponível em: < http://www.sbf1.sbfisica.org.br/eventos/snef/xvi/cd/>. Data de acesso: 20/mar/2012.

PÉREZ, S; URE, M. de los números al álgebra en cinemática elemental: análisis de un cuestionario. In: ENCONTRO DE PESQUISA EM ENSINO DE FÍSICA (EPEF), 10, 2006, Londrina, PR. Atas do X Encontro de Pesquisa em Ensino de Física. São Paulo: Sociedade Brasileira de Física, 2007. 1CD-ROM.

PIETROCOLA, M. Linguagem e estruturação do pensamento na ciência e no ensino de ciências. (p. 315 - 333). Filosofia, Ciência e História - Michel Paty e o Brasil, uma homenagem aos $\mathbf{4 0}$ anos de colaboração - FAPESP - Editora Discurso Editorial - São Paulo - 2005.

PIETROCOLA, M. A matemática como estruturante do conhecimento físico. Caderno Brasileiro de Ensino de Física, v.19, n.1, p.93-114., 2002.

POINCARÉ, H. O valor da Ciência. Rio de Janeiro: Contraponto, 1995.

ROCHA, I.; FIGUEIREDO E PAULA, H.; Um exemplo de contribuição do ensino de física para o ensino de matemática. In: SIMPÓSIO NACIONAL DE ENSINO DE FíSICA (SNEF), 18, 2009, Vitória, ES. Anais do XVIII Simpósio Nacional de Ensino de Física. Disponível em: <http://www.sbf1.sbfisica.org.br/eventos/snef/xviii/>. Data de acesso: 20/mar/2012.

ROSA, M.B. "A construção do conceito de função em atividades integradas entre a matemática e a física." Dissertação de Mestrado. PONTIFÍCIA UNIVERSIDADE CATÓLICA DO RIO GRANDE DO SUL - EDUCAÇÃO EM CIÊNCIAS E MATEMÁTICA, 2005.

SALES G.; et al. O oa - gangorra interativa e a interdisciplinaridade matemáticafísica. In: SIMPÓSIO NACIONAL DE ENSINO DE FÍSICA (SNEF), 17, 2007, São Luis, MA. Anais do XVII Simpósio Nacional de Ensino de Física. Disponível em: 
<http://www.sbf1.sbfisica.org.br/eventos/snef/xvii/atas/trabalhos.htm> acesso: 20/mar/2012.

SILVA, D.; PACCA, J. Contribuições de brahe, kepler, newton e da matemática na construção da lei da gravitação. In: SIMPÓSIO NACIONAL DE ENSINO DE FÍSICA (SNEF), 19, 2011, Manaus, AM. Programação do XIX Simpósio Nacional de Ensino de

Física.

Disponível

em: <http://www.sbfisica.org.br/ snef/xix/index.php?option=com_wrapper\&view=wrapper \&ltemid=16>. Data de acesso: 20/mar/2012.

SILVA, J.; MOYSÉS LUIZ, A. A relevância da metrologia no ensino médio. In: SIMPÓSIO NACIONAL DE ENSINO DE FÍSICA (SNEF), 16, 2005, Rio de Janeiro. Anais do XVI Simpósio Nacional de Ensino de Física. Disponível em: < http://www.sbf1.sbfisica.org.br/eventos/snef/xvi/cd/>. Data de acesso: 20/mar/2012.

SILVA JÚNIOR, G.; GAZIRE, E. Ensino de física e matemática: diálogos possíveis. In: SIMPÓSIO NACIONAL DE ENSINO DE FÍSICA (SNEF), 18, 2009, Vitória, ES. Anais do XVIII Simpósio Nacional de Ensino de Física. Disponível em: <http://www.sbf1.sbfisica.org.br/eventos/snef/xviii/>. Data de acesso: 20/mar/2012.

SILVA, H.; LUZ, K. Revisitando a prática de resolução de lista de exercícios: linguagem matemática, linguagem verbal e significação física em ambiente virtual de aprendizagem. In: SIMPÓSIO NACIONAL DE ENSINO DE FíSICA (SNEF), 20, 2013, São Paulo, SP. Trabalhos do XIX Simpósio Nacional de Ensino de Física. Disponível em: <http://www.sbf1.sbfisica.org.br/eventos/snef/xx/atas/trabalhos.htm>. Data de acesso: 10/jun/2014.

SILVA, O.; GARCIA, N. Aspectos físico e matemático no ensino do conceito de campo elétrico. In: SIMPÓSIO NACIONAL DE ENSINO DE FíSICA (SNEF), 18, 2009, Vitória, ES. Programação do XVIII Simpósio Nacional de Ensino de Física. Disponível em: <http://www.sbf1.sbfisica.org.br/eventos/snef/xviii/>. Data de acesso: 20/mar/2012.

STEWART, lan. 17 equações que mudaram o mundo. $1^{\text {a }}$ edição, São Paulo: Jorge Zahar, 2013.

VIZCAÍNO, D.; TERRAZZAN, E. Identificando os significados de "matematização" num curso de licenciatura em física. In: ENCONTRO DE PESQUISA EM ENSINO DE FíSICA (EPEF), 14, 2013, Maresias, SP. Programação do XIII Encontro de Pesquisa em Ensino de Física. São Paulo: Sociedade Brasileira de Física. Disponível em: < http://www.sbf1.sbfisica.org.br/eventos/epef/xiv/programa/>. Data de acesso: 20/mar/2012. 
ANEXOS 


\section{Ensaio: a natureza pelos números, os números pela natureza.}

A Física. Parece-me que ela possui várias facetas, a maioria, caricaturadas: a Física da escola, a Física da universidade, a Física dos laboratórios, a Física do mundo acadêmico, etc. São várias imagens de uma ciência que extrapola cada uma delas, não é na intersecção ou na união de cada uma que surge a inefável Ciência; falta, falta muito a edificar em cada face para alcançá-la. Mas ela existe, única, explorável, nem sempre palpável, mas existe.

Ao pensar sobre essa Física, imediatamente surge o pensar sobre a natureza e as relações que ela tece com a ciência. Não pretendo nessa apresentação definir a Física, por acreditar que ela é inexprimível e além do que qualquer frase possa estabelecer. No entanto, é importante visualizar o universo que ela possui e pertence, um universo tão amplo que ultrapassa as definições, fórmulas e formalidades, um universo físico, composto pela natureza física.

Mas afinal, que natureza seria essa? Ao aprender sobre a natureza, ainda no ensino fundamental, a vimos como o espaço livre da intervenção antrópica, ou seja, o ambiente onde o homem não chegou, não explorou, não interveio. Espaços "puros", onde os acontecimentos seguem o ciclo natural, ondem os rios correm sem desvios e poluição, onde o solo se mantém intacto e é o lar de inúmeras espécies não humanas.

Ao observar essa natureza, já a estamos vendo com uma lente particular, já existe a ação humana ao defini-la como tal. Não somos o centro do universo e da natureza, mas interagimos com eles, pertencemos a eles, seja pelo simples fato de descrevê-los, imaginá-los, vivenciá-los. Por conta disso, a natureza física, maior que essa definição ingênua de natureza, não pode e nem deve ausentar o ser humano de seu convívio: ambos estão em uma simbiose, ou seja, em uma relação que obrigatoriamente é vantajosa pelo menos para um dos entes, tornando-os como um único organismo. Pode-se dizer então que a natureza física se caracteriza não só por seus elementos, mas também por suas inter-relações. 
Como traduzi-la? Como explaná-la? Como a ciência interpreta essa natureza, tão rica de informações, com tantos segredos? A primeira impressão a respeito dela vem do sentir. Fernando Pessoa, em um de seus pensamentos, cita: "Sentir é criar. Sentir é pensar sem ideias, e por isso sentir é compreender, visto que o Universo não tem ideias". O universo não tem ideias, assim como a natureza, ela tem informações. Essas informações podem ser decodificadas, surgindo assim ideias.

Um jeito de decodificar ou traduzir a natureza física se manifesta, pelo sentir, através da matemática.

A matemática, ciência exata, manifestada por meio do sentir? Os números, que muitas vezes representam uma racionalidade que expulsa qualquer emoção, que são vistos como gélidos, ínfimos perante a complexidade das coisas, esses mesmos números advém da abstração de um sentimento?

Sim, em uma visão poética a matemática é a mais bela expressão da natureza física e ela sucede a ação humana- consciente e inconsciente - de sentir. É sentir com o pensamento, é um sentir não necessariamente doído (mas pode ser angustiante), é o sentir da intuição, da reflexão, da observação, da perseverança. É a tradução doce dessas inúmeras informações que a natureza física nos disponibiliza.

Mas qual o papel que a matemática exerce na Física? É possível "enquadrála" como uma personagem na construção da ciência?

Primeiramente, pensemos na matemática atuando como instrumento da Física. Ser instrumento é ser utilizável para executar algo, é ser ferramenta, fazer medições, é ser mero objeto, ser descartável, substituível. Usamos uma pá para cavar pequenas coisas, e uma enxada para substituí-la, ambos os instrumentos para uma mesma ação, que podem ser substituídos por inúmeros outros, para executar precisamente a mesma tarefa. Ao pensar na matemática, será que é esse o papel que lhe cabe na Física? Depende. Em muitos casos, esse é o palco dos números, o da instrumentação. Utilizamos a matemática com essa finalidade ao fazer medições, na escolha de variáveis, etc.

Mas podemos enxergar uma atuação mais ampla da matemática na física. Ela cava ideias através de informações da natureza física, as traduz, e sua forma de agir, oriunda do sentir, é única e insubstituível. Podemos sentir a natureza com outros elementos, mas a ação - ideia- gerada por eles é diferente da gerada pela 
matemática. Os números e sua extensão cavam uma tarefa particular que só eles podem transmitir, não existe instrumento que gere exatamente as mesmas ideias e reflexões.

Ao realizar essas reflexões, vejo que a matemática está para a Física assim como a música está para a arte. Ela está inserida ao outro como representação, assim como com a matemática podemos expressar conceitos físicos através de equações, fórmulas e números, com a música podemos externar fielmente um sentir que representa a arte.

Para Fernando Pessoa, "A finalidade da arte não é agradar. O prazer aqui é um meio; não é neste caso um fim. A finalidade da arte é elevar." Não seria esta também a finalidade da Física? Elevar o pensamento, o conhecimento, o saber? O prazer de conhecê-la, de vivenciá-la é só um meio para a construção do conhecimento, e nessa edificação a matemática é um importante pilar. É o único? Não, assim como a música não é o único alicerce da arte, mas ambas cumprem importante função. Para a relação entre a Matemática e a Física, que função cabe à primeira?

Como podemos pensá-la? Para a ciência, e a Física em especial, ela é universal, ultrapassa barreiras ideológicas, culturais, socioeconômicas. Por conta disso, a atuação da matemática pode ser vista como uma linguagem.

Linguagem é um meio sistemático de expressão de ideias ou sentimentos com o uso de marcas, sinais ou gestos convencionados, qualquer sistema de símbolos e sinais ou ainda um linguajar. Ela pode ser verbal ou não verbal, e sempre exprime uma mensagem. Ao se acenar para um amigo com a mão transmito a mensagem de cumprimento ou despedida, ao visualizar uma placa de trânsito interpreto sua informação sem que nada nela esteja escrito. São linguagens simples, mas úteis como forma de expressão.

Na matemática temos um sistema de códigos com números, com raciocínios lógico-dedutivos, temos construções que originaram a álgebra, as geometrias, etc., um dialeto próprio dessa arte, que usamos, manipulamos, e através de seus mecanismos, interpretamos e decodificamos ideias. Com ela, podemos "usurpar" teoremas, simbologias e relacioná-las com o mundo físico, podemos traduzir imagens, conhecimentos e ações com esse intenso sistema que ela possui. Outra 
mensagem que a matemática passa é a mensagem da Física, ela é linguagem pura e encantadora da ciência.

Acredito que ser linguagem é ser mais que instrumento, ser linguagem é participar do sentir, da interpretação do sentir e da transmissão da mensagem que ele nos traz, é mais que executar uma ação, é ser a ação determinante para o surgimento e/ou confirmação dos conceitos, das teorias, da Física.

Portanto, a matemática pode se mostrar então, como a linguagem da natureza física. Uma linguagem que tem como primeiros símbolos os números, que se desenvolveram e junto com as construções humanas, evoluíram para outros signos mais amplos. É importante ressaltar que ao falar em números nessa reflexão, intuito que eles mimetizem toda a matemática, numa visão simplista e minimalista de representação.

Ao falar sobre a Física, a natureza física e sua tradução, busco a natureza pelos números, assim como consigo visualizar os números pela natureza, em uma relação consensual e cíclica indefinível.

Nessa breve reflexão, alguns exemplos explanam como enxergo a complexa relação da matemática com a natureza física.

Vejamos primeiramente a sequência de Fibonacci, que representa com maestria a natureza pelos números. Através de um sequenciamento simples de reprodução de coelhos chegou-se aos incríveis números $\{1,1,2,3,5,8,13,21,34,55,89 \ldots\}$ que aparecem em várias situações e observações na natureza. Essa mesma

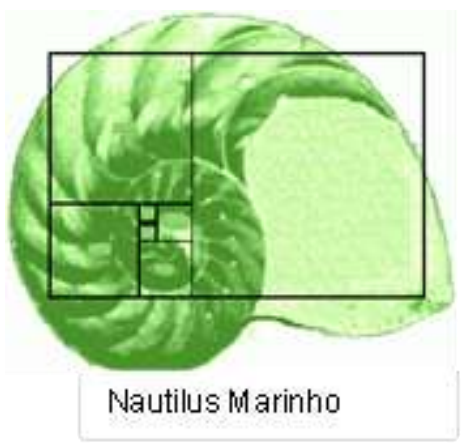
sequência representa o estudo genealógico das abelhas, o crescimento de plantas, curvas com a forma espiralada como o Nautilus Marinho, nas possibilidades de reflexão da luz em uma fibra dupla de vidro, nas formas espiraladas das galáxias, na onda no oceano, etc. Através dela chegamos na razão áurea e sua visualização também nas artes (como em Monalisa de Leonardo da Vinci) etc.

A regularidade dos números e das figuras geométricas nas plantas, animais, nos fenômenos físicos, em qualquer ser que se pode estudar, é ao mesmo tempo fascinante e misterioso. Como podem números dizer tanto? Como podem representar tamanha perfeição? É a natureza, vista através dos números. 
Passamos por Pitágoras e sua interpretação dos intervalos musicais. Ao utilizar-se de uma corda tensionada, ele percebeu que reduzindo seu tamanho com razão $1 / 2$, encontrava-se tons iguais em oitavas acima, e ainda, nessa experiência foi possível perceber que com um número menor de oscilações tem-se sons mais graves e um número maior tem-se sons mais agudos, estabelecendo uma relação entre o comprimento da corda e a frequência do som audível. Como ele, utilizando de simples razões e proporções, conseguiu interpretar a música e iniciar a construção do que hoje vemos como escala musical? Como os números podem representar o som, a arte? Não seria, nesse caso, os números agindo pela natureza?

Os números agindo a favor dela, nos servindo com decodificações que antes pareceriam impossíveis, nos presenteando. $O$ sistema numérico (lembre-se que aqui eles representam toda a matemática) embalando a construção musical assim como uma melodia que aprecio embala e inspira os sentimentos.

$\mathrm{Na}$ arte, também é possível encontrar mais argumentos que demonstram a íntima relação entre a física e a matemática e como a transmissão de mensagens se dá através dela.

Um artista que transita entre os diversos "mundos" é M.C. Escher e suas inúmeras preciosidades. Quantas informações da natureza física podemos extrair de sua arte?

Na obra "Uma mão com uma esfera refletora" vejo a amplitude dessa pergunta com a dimensão das respostas que posso fornecer. A esfera, perfeita, no centro da gravura, na mão de um homem, pode ser vista como o geocentrismo. Na busca de perfeições e

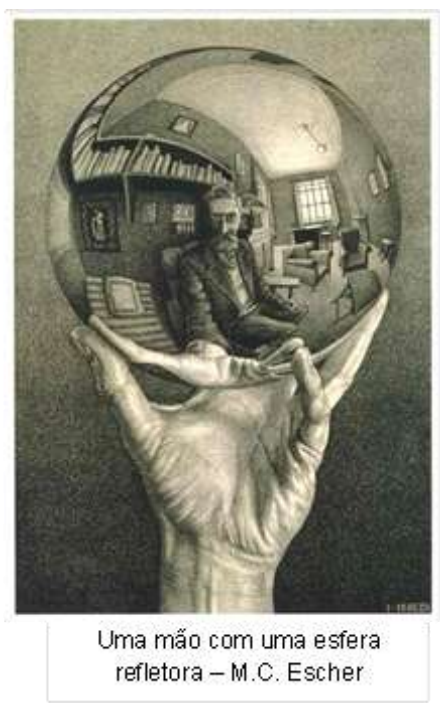
simetrias a matemática é sentida com essa bela esfera refletora, que nos permite ver, mesmo com deformações, todo o objeto gerador da imagem. É o homem dominando o homem, o homem como centro das atenções. Sua reflexão é centralizada e ele é o principal sujeito dessa imagem, o menos distorcido. $O$ ego deformador nos mostra como ele se vê, vê seu mundo e a natureza física. Tudo parte dele, as sensações, a arte, a matemática, a física. Com que mão esse ser 
segura a esfera refletora? Que leis são essas que permitem o fenômeno físico? Há mais espaço para ele no além-quarto?

Há mais espaço para nós no além-quadro. Infinitas possibilidades de questionamentos, identificações, etc.. Em muitas de suas obras, Escher se utiliza da pura matemática para expressar sua natureza, como por exemplo, representações que se utilizam de outra geometria que não a euclidiana (esférica, hiperbólica...). Essa matemática, nem sempre explícita nas gravuras mas presente em sua obra, não pode ser entendida como mero instrumento da arte. É mais, é linguagem, nos transmitem mensagens com códigos próprios, nos permitem interpretar a imagem, observá-la mais de perto. É a mais clara demonstração que a matemática advém do sentir. Quer melhor exemplo da abstração de sentimentos que uma obra de arte nos permite conhecer?

Expandindo as reflexões, podemos pensar no papel da matemática na Física Clássica e na Moderna. Classicamente, podemos obter precisamente as posições, velocidades, energia de objetos e entes físicos em um mundo macroscópico através dos "números". A matemática, nesse caso, age com a importante função de representar as grandezas físicas, de determinar e quantificar movimentos, etc.

Com a descoberta da constante de Planck, com o Nobel de Einstein pelo estudo do efeito fotoelétrico e com o princípio da incerteza, o papel da matemática, seu "efeito" nas construções, se modificou. Ela não mais determina, mas demonstra o incerto, não cria mais exatidão, e sim efeitos probabilísticos.

É a mesma matemática, é a mesma "música", tocada por instrumentos (ou artistas) diferentes! A mudança de "timbres" nos fornecem novos sentidos, ideias e construções. Ao se olhar para uma equação de onda de Schrodinger, observamos, manejamos o $\boldsymbol{i}$, um número imaginário, que não representa uma grandeza física, mas faz a "canção" ser harmoniosa.

Olhamos também para a relatividade. Ao estudar a relatividade restrita, a matemática representa um importante papel nas equações de Lorentz, nos rotacionais e suas inter-relações, no significado dos resultados numéricos nas aplicações com eventos, etc. Na restrita, não se fala em espaço e tempo, e sim em eventos. Já ao estudar a Relatividade Geral, não se fala também em massa. A relatividade geral é geométrica, uma teoria para o tensor métrico. Com a 
"descoberta" da geodésica, do raio de Schwarzchild, das comparações com as Leis de Newton, percebemos o papel estruturante da matemática nessa teoria.

Podemos usá-la indefinidamente. Podemos saber mais dela, e com isso, saber mais Física, saber mais da natureza física. Saber usar a matemática é poder, é ter autonomia para transitar entre teorias, ideias, questionamentos, é se colocar diante do conhecimento.

Diante de todos os argumentos trazidos nessa breve justificativa, acredito não ser possível ensinar ou aprender física sem a matemática.

Apesar de, no quadrículo da sala da aula, em algum livro didático, estar escrito: "A Física é a ciência que estuda os fenômenos da natureza" a ideia da física, sua natureza e sua linguagem não pode ser limitada. A natureza da Física é maior: das pessoas - seus pensamentos e criações- e das coisas. E essa natureza está intimamente relacionada com a matemática, como foi discorrido no decorrer do texto.

Essas reflexões explicitam as motivações da pesquisa realizada. $O$ intuito desse trabalho é buscar, através do estudo das relações existentes entre a física e a matemática, a pluralidade que nos imprime o Universo, como Fernando Pessoa nos convidou no início dessa apresentação.

Imagens retiradas de:

http://www.uel.br/projetos/matessencial/alegria/fibonacci/seqfib2.htm Acessado em 04/2012

http://www.educ.fc.ul.pt/docentes/opombo/seminario/escher/obra3.html Acessado em 04/2012 


\section{Fichas das aulas}

\begin{tabular}{|l|l|}
\hline Aula I - Turma A & Código: IA \\
\hline Gravação: 01A (20/03) & Duração: 01:23:12 \\
\hline
\end{tabular}

Descrição Sintetizada:

- Comentários dos erros cometidos pelos alunos em exercícios que foram propostos online sobre unidades de medida e análise dimensional;

- Início do estudo da velocidade instantânea e aceleração instantânea para o movimento unidimensional;

- Interpretação geométrica de um gráfico;

- Velocidade média;

- Revisão de conceitos matemáticos: o que é limite? O que é derivada? Como derivar polinômios?

\begin{tabular}{|l|l|}
\hline Aula II - Turma A & Código: IIA \\
\hline Gravação: 02A (27/03) & Duração: 00:30:16 \\
\hline
\end{tabular}

\section{Descrição Sintetizada:}

- Derivadas e Integrais: descrição da invenção do cálculo para descrever a mecânica, de Newton a Leibnez;

- Notações diferentes para descrever a velocidade instantânea;

- Interpretação geométrica da derivada;

- Comentários da provinha;

- O conceito de Integral;

- Teorema fundamental do cálculo e vídeo: Universo Mecânico. 


\begin{tabular}{|l|l|}
\hline Aula III - Turma A & Código: IIIA \\
\hline Gravação: IIIA (10/04) & Duração: 01:26:06 \\
\hline
\end{tabular}

\section{Descrição Sintetizada:}

- Início do estudo do movimento bidimensional;

- Diferença entre grandeza vetorial e escalar;

- Revisão sobre vetores: o que são, como fazer projeção, etc.

\begin{tabular}{|l|l|}
\hline Aula IV - Turma A & Código: IVA \\
\hline Gravação: IVA (17/04) & Duração: 01:23:19 \\
\hline
\end{tabular}

\section{Descrição Sintetizada:}

- Aceleração;

-MRUV: movimento retilíneo uniformemente variado;

- Aplicações do MRUV;

-Equação da trajetória;

- Resolução comentada de exercícios;

\begin{tabular}{|l|l|}
\hline & \\
\hline Gravação: VA (20/04) & Duração: 01:30:38 \\
\hline
\end{tabular}

Descrição Sintetizada:

- Resolução comentada de exercícios (lançamento horizontal e lançamento oblíquo);

- Movimento circular uniforme;

- Diferentes descrições: cartesiano e coordenadas polares;

-Exemplos de MCU. 
Gravação: VIA (24/04)

Duração: 01:37:35

Descrição Sintetizada:

- Movimento circular;

- Formas vetoriais, sistema de coordenadas polares e movimento circular arbitrário.

\begin{tabular}{|l|l|}
\hline Aula VII - Turma A & Código: VIIA \\
\hline Gravação: VIIA (04/05) & Duração: 01:23:58 \\
\hline
\end{tabular}

Descrição Sintetizada:

- Explicação sobre derivadas e integral;

- Velocidade e aceleração;

\begin{tabular}{|l|l|}
\hline Aula I - Turma B & Código: IB \\
\hline Gravação: IB (20/03) & Duração: 00:54:23 \\
\hline
\end{tabular}

Descrição Sintetizada:

- Comentários e correção dos exercícios da lista de exercícios online;

- Gráfico velocidade por tempo e obtenção do deslocamento;

- Gráfico aceleração por tempo;

- Exercício em aula. 


\begin{tabular}{|l|l|}
\hline Aula II - Turma B & Código: IIB \\
\hline Gravação: IIB (27/03) & Duração: 00:45:38 \\
\hline
\end{tabular}

\section{Descrição Sintetizada:}

-Significado da área sobre a curva v(t) e a(t);

- Comentários sobre a provinha;

-Exercício em aula: gráfico aceleração por tempo.

\begin{tabular}{|l|l|}
\hline Aula III - Turma B & Código: IIIB \\
\hline Gravação: IIIB (30/03) & Duração: 00:50:03 \\
\hline
\end{tabular}

Descrição Sintetizada:

- Referência: sistema de coordenadas cartesianas e esféricas;

- Operações básicas com vetores;

-Trabalho para a sala: exercício sobre o estudo do movimento.

\begin{tabular}{|l|l|}
\hline Aula IV - Turma B & Código: IVB \\
\hline Gravação: IVB (10/04) & Duração: 01:24:36 \\
\hline
\end{tabular}

\section{Descrição Sintetizada:}

- Correção de um exercício da lista online;

-Movimento bidimensional: equação horária, velocidade e aceleração;

- Exercício em aula;

- Lançamento oblíquo. 


\begin{tabular}{|l|l|}
\hline Aula V - Turma B & Código: VB \\
\hline Gravação: VB (20/04) & Duração: 00:49:08 \\
\hline
\end{tabular}

Descrição Sintetizada:

- Aula de resolução de exercícios: lançamento oblíquo e lançamento horizontal.

\begin{tabular}{|l|l|}
\hline Aula VI - Turma B & Código: VIB \\
\hline Gravação: VIB (24/04) & Duração: 01:30:44 \\
\hline
\end{tabular}

Descrição Sintetizada:

- Movimento circular;

- Exercício sobre o MCU em aula. 